\title{
Finest frugt - om 'den Vartou Kjallingepræst': En guide til Grundtvig-Studier 1948-2008, I
}

\author{
Af Aage Jørgensen
}

Grundtvig-Selskabet af 8. september 1947 lancerede allerede i 1948 en årbog, Grundtvig-Studier. Artiklen her gør status over indholdet i de 60 årgange, som det efterhånden er blevet til. En væsentlig del af debatten omkring efterkrigstidens mange Grundtvig-disputatser såvel som talrige andre forskningsbidrag er fremkommet netop i Grundtvig-Studier. Trods forfatterskabets "grænseoverskridende" karakter systematiserer artiklen sin præsentation af materialet traditionelt. De indledende afsnit omtaler de bibliografiske og editionsfilologiske bidrag samt det biografisk-personalhistoriske stof. Derefter karakteriseres i en række større afsnit (1) det idehistoriske stof, der drejer sig om livs- og historiesynet, samt forholdet til den romantiske filosofi, den nordiske mytologi og i det hele taget til samtidens tænkemåde, (2) det litteraturhistoriske og æstetiske stof, med vægt på en række forskeres eksemplariske indsats (Gustav Albeck, Helge Toldberg, Jørgen Elbek, Flemming Lundgreen-Nielsen, Sune Auken og for den angelsaksiske indflydelses vedkommende S. A. J. Bradley), og (3) det teologiske stof, med fokus især på eftervirkningen af Kaj Thanings udpegning af 1832 som afgørende vendepunkt i Grundtvigs liv og på forholdet til Luther, Kierkegaard og den mystiske tradition. Udforskningen af Grundtvigs salmer og prædikener behandles i særlige afsnit, og endelig beskæftiger et afsnit sig med belysningen af hans politiske indsats. Årbogens bidrag om Grundtvigs pædagogiske overvejelser og disses betydning for den danske skole, specielt folkehøjskolen, samt i det hele taget eftertidens reception af hans tanker (i Danmark som ude i den store verden) vil blive diskuteret ved senere lejlighed.

Med høj cigarføring spåede Gyldendal-direktøren Ingeborg Andersen i 1948, at en årbogsudgivelse betitlet Grundtvig-Studier (i det følgende: $G r S t$ ) nok ville blive en vanskelig og kortvarig affære. Den forudsigelse kom ikke til at holde stik, skønt der snart dukkede et "i kommission hos" op på titelbladet, som overlevede til og med årgang 2006. Ikke blot har Grundtvig-Selskabet efterhånden bragt 60 årgange på gaden, men årgangene er også i dag adskilligt tykkere, end man dengang turde fable om. ${ }^{1}$

Summa summarum: $72 \mathrm{~cm}$ på hylden, 19,4 kg på vægten. Første årgang kostede kr. 9,50. I rækken indgår to dobbeltbind (GrSt 1977-78 og GrSt 198990). Sidetallet svinger mellem 75 (GrSt 1972) og 337 (GrSt 1989-90). Indholdsoversigter og registre til årgangene 1948-1987 er fremkommet i GrSt 1957, 1967 og 1987. 
Talen skal her være ikke om Selskabets aktivitet i bred bemærkelse, men specifikt om $\mathrm{rSt}^{2}{ }^{2} \mathrm{Om}$ Selskabet har årbogen bragt bidrag af Henning Høirup ved 10- og 40-årsjubilæerne (GrSt 1957 og 1987) og af William Michelsen ved 50-årsjubilæet (GrSt 1997). Begge forfattere pointerer vigtigheden af det etablerede samarbejde mellem forskere på tværs af traditionelle fagopdelinger foran det mangfoldige, vidtspændende forfatterskab. ${ }^{3}$ Hertil kommer, at Selskabets formandsberetninger siden 1958 har været fast inventar i GrSt, også et bidrag til historieskrivningen.

Grundtvig er mindre verdensberømt end sine verdensberømte samtidige, H. C. Andersen og Søren Kierkegaard, men dels holder han sig smukt i forhold til dem på hjemmebanen, og dels har han i de senere årtier, især takket være Selskabet, påkaldt sig en stigende international opmærksomhed. Forskningsintensiteten fremgår ikke mindst af den række disputatser, som har set lyset siden Selskabets stiftelse: Henning Høirup, Helge Toldberg, William Michelsen, Kaj Thaning, K. E. Bugge, Flemming Lundgreen-Nielsen, Helge Grell, Bent Christensen, Ole Vind, Sune Auken og Regner Birkelund. Hertil kan lægges de norske og svenske: Sigurd Aarnes, Synnøve Heggem og Pål Henning Walstad - og Tord Ehnevid, Harry Aronson og Bosse Bergstedt. ${ }^{4}$ H. C. Andersen kan ikke mønstre noget lignende, Kierkegaard kan kun, om man medtæller de talrige udenlandske afhandlinger i disputatsklasse. Begge har på det seneste fået deres skrifter udsendt i videnskabelige udgaver - for Grundtvigs vedkommende går den afskrækkende kalkule ud på, at hans samlede trykte forfatterskab vil fylde 125 bind. Det utrykte materiales omfang er aldrig blevet kalkuleret.

Stiftelsestidspunktet, lige efter Anden Verdenskrig, var selvfølgelig ikke "tilfældigt". Selskabet udsprang af et behov for koordinering af en række forskeres arbejde og for et debatforum. Den oprindelige grnppe bestod af seks forskere, men hastigt udvidede grnppen sig til en

2 Guiden er bredt favnende, men ikke alt omfattende. Organiseringen er diskutabel af den enkle grund, at Grundtvigs liv og forfatterskab, og følgelig også hvad der er skrevet derom, truer med at sprænge kategoriseringerne. Anmeldelser er kun undtagelsesvis tilgodeset. - Del II vil fremkomme i GrSt 2010 og især fokusere på den pædagogiske side af sagen (inkl. højskoletanken), samt på virkningshistorien - i Danmark, Norden, Europa, Verden.

Jf. S. A. J. Bradleys bidrag om Selskabets tilblivelse, hvis titel citerer fra formålsparagraffen: "To establish a free and open forum" (Gr-St 2005). I realiteten er der tale om en gengivelse med oversættelse af og kommentarer til Henning Høirups skildring af sagen i erindringsskriftet Så fjern og dog så næer (1991).

4 Den allerførste Grundtvig-disputats skyldes svenskeren Sven Bergentz (N. F. S. Grundtvigs religiösa idealism med särskild hänsyn till hans etiska ståndpunkt, 1923). 
styrelse, hvorom en medlemsskare fylkedes, der kunne bakke forskningsindsatsen op og udgøre dens primære publikum. Denne strukturering sikrede såvel bredden som dybden, og et forretningsudvalg sikrede en effektiv drift.

De store linjer i Grundtvig-forskningen trækkes op især gennem disputatsrækken. Men efter Selskabets erklærede princip er GrSt hjemsted for i hvert fald en del af den debat, som udfolder sig omkring disputatserne. Et stærkt eksempel herpå er debatten om Kaj Thanings gedigne Menneske først - (1963), som gennem en årrække var retningsgivende - og som delte forskerne i fløje, der dog forblev i stue sammen og forblev enige om, at samtalen var mere afgørende end grundsynspunkterne. Jørgen I. Jensen citerer Poul Borum for den bemærkning, at man ikke skulle spørge Thaning, hvad klokken var, for svaret blev uvægerligt 18.32 (nekrolog, GrSt 1997). 1832 markerer efter Thanings opfattelse det helt afgørende vendepunkt hos Grundtvig, året for hans definitive overgang til en "humanistisk" religiøs opfattelse. Blandt de forskere, som problematiserede opfattelsen, var Kim Arne Pedersen, der skrev Thanings nekrolog (GrSt 1994), men også, som det pointeres dér, for eksempel Regin Prenter og på andet grundlag William Michelsen. (De fleste af disputatserne indgik i Grundtvig-Selskabets skriftrække, der efterhånden tæller 38 numre).

GrSt skaber forbindelse og udfyldning mellem specielt de større separattrykte arbejder og udgør det naturlige "samlingssted" for talrige forskningsbidrag, der ellers ville være blevet spredt i vidt forskellige publikationer (eller være forblevet utrykte).

Man kan ved sammenligning af de ældre og de yngre årgange se, at der er sket forskydninger i forskningsinteressen. Men på grund af overlapning mellem redaktionerne finder man ikke markante ændringer. Det skulle da være det ryk i teologisk retning, som etableringen af Center for Grundtvigstudier ved Aarhus Universitet medførte.

Årbogens første redaktør var Henning Høirup (1948-52). Efter ham fulgte Gustav Albeck (1953-95), der først var alene på posten, men derefter dannede par med William Michelsen (1969-2002), indtil der $\mathrm{i}$ forbindelse med omfangsforøgelsen ved Center for Grundtvigstudiers oprettelse kom yderligere to medlemmer ind i redaktionen: Hellmut Toftdahl (1989-95) og Jens Holger Schjørring (1989-2007). Albeck blev afløst af Flemming Lundgreen-Nielsen (1996-97 og 1999-), Toftdahl af Kim Arne Pedersen (1996-), Michelsen af S. A. J. Bradley (2002-) og Schjørring af Ulrik Overgaard (2008-). 
Grundtvig-Selskabet blev stiftet af seks herrer i Ribe Bispegård, som bekendt 8 . september $1947,{ }^{5}$ og forskningen forblev meget langt hen et herrejob. Endnu har ingen kvinde sat sine ben i forretningsudvalget, endsige i GrSt-redaktionen. Den første kvinde i styrelsen var franske Erica Simon, indvalgt 1981. I 2008 var der fire kvinder i repræsentantskabet, de tre med udenlandske adresser: Synnøve Heggem, Hanne Sanders og Kirsti Aasen. Erica Simon tegnede sig i 1969 for GrSt's første "kvindebidrag" - og er i øvrigt den hidtil eneste kvinde, som årbogen har betænkt med en nekrolog (GrSt 1993). Den første artikel skrevet af en dansk kvinde (Bodil Schmidt) dukkede op i GrSt 1980. Hellmut Toftdahl taler et sted en passant om Grundtvig-forskningens "noble herrer", og Sigurd Aarnes nævner dens "engasjerte og til sine tider inspirerte menn".

For forskningshistorikken gælder, at man ud over de konkrete behandlinger (Høirup, Michelsen og formandsberetningerne) også i høj grad finder stof og synspunkter i nekrologerne, specielt over stiftergenerationens medlemmer. Her skal blot nævnes Kim Arne Pedersens nekrologer over Henning Høirup (GrSt 1996) og William Michelsen (GrSt 2002), også fordi de griber helt tilbage til den Grnndtviginteresse, som kan dateres til 1930'ernes seneste år og til krigstidens Hal Koch-inspiration. ${ }^{6}$

\section{Bibliografi og registrant}

Blandt stifterne var Steen Johansen, hvis firebindsbibliografi over Grundtvigs forfatterskab var langt fremskreden, da mødet i Ribe Bispegård fandt sted. Efter færdiggørelsen af den kom han til at spille en vigtig rolle $\mathrm{i}$ den registrering af Grundtvigs efterladte papirer, som efter intervention fra Hartvig Frisch blev skabt i 1950'erne af seks-otte forskere i Selskabets regi med bistand fra Det danske Sprog- og Litteraturselskab. Registranten udkom i 30 bind 1957-64. ${ }^{7}$ Et meget vigtigt arbejde, afgørende for den videre forfølgelse af det store mål: at gøre alt, hvad Grundtvig skrev, tilgængelig for forskningen, i sidste instans i en række tekstkritiske udgivelser. Selve den opnåede tilgængelighed satte sig igennem i hyppige præsentationer i GrSt af manuskripter fra

Til stede var C. I. Scharling, Villiam Grønbæk, Henning Høirup, Steen Johansen, William Michelsen og Helge Toldberg. Disse udgør da Selskabets founding fathers. Beslutningen blev truffet natten før og bevidnet fra væggen af tre afdøde Grundtvig-opponenter: J. P. Mynster, H. L. Martensen og Henrik Scharling.

6 Michelsen-nekrologen har ligefrem overskriften "Et rids af Grundtvigforskningen og dens stilling i efterkrigstidens Danmark" (GrSt 2002).

7 Registranten omfatter i alt 6624 blade, samt registrets VI $+509 \mathrm{~s}$. 
skatkammeret, gerne med tilknyttede kommenterende og fortolkende artikler. $^{8}$

En gennemgang af de 60 bind GrSt giver et godt indtryk af, hvor enormt vigtigt denne tilgang til de efterladte papirer er. Årbogens allerførste bidrag er for eksempel en kritisk præsentation af et par udkast til "en apologetisk Fortælling" - ved Henning Høirup, der afprøver den formodning, at talen er om et forsøg, Grundtvigs første, til et forsvarsskrift for kristendommen.

Om bibliografiens tilblivelse beretter Steen Johansen i GrSt 1954. Men allerede i GrSt 1951 indledte han en registrering af Grundtviglitteratur, som fortsatte til hans død. Herefter (GrSt 1968 ff.) overtog denne artikels forfatter udarbejdelsen af oversigterne, dog ordnet efter bibliografiske kriterier, hvor Johansen havde tematiseret sin servering af stoffet. I samme årgang skrev han "Om Grundtvig-udgaver" - med indledningsvis henvisning til den store drøm om en ny, samlet, kritisk udgave af forfatterskabet. Den oplysningstunge artikel rækker fra betragtninger over Grundtvigs egne forlagsrelationer, via udgivelsesindsatser af J. K. Madsen, C. J. Brandt og - med betoning af den poetiske side af sagen - Svend Grundtvig, frem til de nyere "udvalgsudgaver", med den måske lidt nedslående konklusion, at der selv i disse sidste er "forholdsvis ringe belæring at hente", hvad angår "en kommende fuldstændig udgave" (og vel at mærke, fordi netop Grundtvigs forfatterskab repræsenterer en unik opgave). Johansen pointerer, at bibliografier ud over at være objektive registreringer også er åndsværker. Han skitserer projektets historie og det omfattende materiale, det tager i betragtning, herunder oplysninger om Grundtvigs liv, blandt andet baseret på hans breve, og han redegør for vanskelighederne især hvad angår registreringen af salmestoffet med dets talrige varierede tryk (for eksempel 25 tryk af "Dejlig er den Himmel blaa", hvortil der knytter sig oplysninger af forskellig art). Den kronologiske ordning af produktionen understreger behovet for en udgivelse af Grundtvigs samlede skrifter, også de utrykte, og den tydeliggør det nære og intense samspil mellem livsomstændigheder af enhver art og litterær virksomhed. ${ }^{9}$

\section{Editionsfilologiske arbejder}

"Nogle bemærkninger vedrørende en samlet udgave af Grundtvigs dagbøger" er Gustav Albecks forskræp i GrSt 1976 til de to bind Dag-

8 I dag satser man i første omgang på en digitalisering af det store materiale.

9 Jf. Eberhard Harbsmeiers bibliografi over Grundtvig-litteratur på ikkeskandinaviske sprog i GrSt 1976. 
og udtogsbøger, han udgav i 1979. Bidraget meddeler løst og fast om den ujævne materialesituation og fremhæver især indførslerne om Steffens-forelæsningerne og om Grundtvigs tidlige læsning.

Flemming Lundgreen-Nielsen udgav i GrSt 1979 subskriptionsindbydelsen for det af Grundtvig og F. C. Sibbern påtænkte - men ikke realiserede - tidsskrift Odin og Saga, 1810. Det skulle efter undertitlen og "de nyeste ideer" behandle "Filosofi, Poesi og Historie". Teksten placerer sig tydeligvis inden for en romantisk konception - "Eenheden af Alt" var det, man ville levere, og som helhed skulle tidsskriftet også "bære Filosofiens Præg og udtrykke dens Aand" - den romantiske filosofi, altså.

200-årsjubilæet bragte flere udgaver, blandt andet to fotografiske optryk: Sang-Veerk til den danske Kirke (med besynderlig udeladelse af det uundværlige kommentarbind, og med negligering af de dér anførte rettelser og tilføjelser) og Danne-Virke. Førstnævnte anmeldes af Henning Høirup (GrSt 1984), sidstnævnte af William Michelsen (GrSt 1985 og 1986), i form af en egentlig "Introduktion til Danne-Virke" (jf. ndf.).

I GrSt 2008 præsenterer Flemming Lundgreen-Nielsen "Rim-Brev til Nordiske Paarørende" i en tekstkritisk, kommenteret version, og i en efterskrift bringer han det på plads i forfatterskabets sammenhæng. Forskningen har besynderligt nok ikke beskæftiget sig ret indgående med det, for eksempel "synes det at være en pointe", at Kaj Thaning i sin disputats nævner det "så lidt som muligt"! Det har LundgreenNielsen nu rådet bod på, de 258 vers kommenteres tæt og nøjeregnende over hen ved 40 sider. Den "Lap af Lokes Sko", som nævnes i vers 146, udløser for eksempel en kommentar over godt og vel en side, og skam få den, som tænker ilde derom.

Hertil kommer en del mindre tekster af Grundtvig, samt nogle breve. $^{10}$

10 Mindre tekster: se for eksempel "Pilegrimen og Pilegrimen fra Zante. Grundtvigs Udkast til en apologetisk Fortælling" (GrSt 1948 ved Henning Høirup), "N. F. S. Grundtvig: 'Indfald"” (GrSt 1949 ved Helge Toldberg), "Et uænset egenhændigt vidnesbyrd om Grundtvigs ungdom" (GrSt 1955 ved Helge Toldberg), "To optegnelser af Grundtvig fra kriseåret 1810" (GrSt 1956 ved William Michelsen), "Grundtvigs tale ved det udvidede landemode i juli 1812" (GrSt 1958 ved K. E. Bugge), "Et af Grundtvig paa tysk skrevet tilbageblik paa sig selv fra vinteren 1813-14" (GrSt 1958 ved Steen Johansen) og "Til Asylernes Venner og Veninder" (GrSt 2006 ved Ulrik Overgaard). Breve: se for eksempel GrSt 1952 og 2002 (Grundtvig og hustruen Lise), GrSt 1957 (Grundtvig og Nicolai Faber), GrSt 2005 (Grundtvig og flere venner), GrSt 2007 (Grundtvig og V. H. Rothe) og GrSt 2008 (Grundtvig og G. P. Brammer). 


\section{Biografisk-personalhistorisk stof}

Især i de første år fremkom i GrSt en række bidrag, der blandt andet med støtte i registranten-in-progress fyldte biografiske hjørner ud og føjede træk til billedet af "den Gamle" (også som ung).

Gustav Albecks "Huslæreren på Egeløkke" (GrSt 1959) supplerer vores indsigt i Grundtvigs forelskelse i Constance Leth ud fra hendes søns karakterbog, samt dagbogsoptegnelser. Hendes lette flirt med den kluntede, retlinede yngling er nok fra begyndelsen blevet misforstået. Han kom fra det ved bøgernes hjælp og blev jo af P. N. Skougaard opmuntret til at fordybe sig i mytologien, som skildret af Albeck allerede i "Grundtvigs Vej til de norrøne Skrifter" (GrSt 1953). ${ }^{11}$

Grundtvigs forhold til grev Danneskiold-Samsøe på Gisselfeld belyses af Jens A. Nielsen (GrSt 1961 og 1962). Greven støttede Grundtvigs "hele danskboglige Virksomhed" langt ud over det forventelige og var således en "ægte" adelsmand, der fortjente og gouterede, at Verdens Krønike (1812) blev dediceret til ham. Artiklens del II leverer en detaljeret gennemgang af en levnedsbeskrivelse, som havarerede, og et omfangsrigt "Efter-Mæle paa Riim", trykt i 1828, der også kan ses som "en eksistentiel redegørelse for Grundtvigs egen udvikling som digter".

I Henning Høirups fremstilling af Grundtvigs sindssygdom i 1867 (GrSt 1951) er den "yderste korthed", som kendetegner ældre biografiers omtale, erstattet af 60 siders dokumentarisk grundighed. Krisens - også de foregåendes - model synes at have været, at tilliden til egen verdensforbedrende evne nedbrydes, $\mathrm{og}$ at Grundtvigs tro så genrejser ham fra den totale afmagt. Materialet fremlægges ikke blot som udtryk for historisk redelighed, men også og især ud fra den erkendelse, at "indsigt $\mathrm{i}$ sindssygens extreme ytringer hos geniale personligheder" $\mathrm{i}$ sidste instans kan hjælpe til "bedre forståelse af deres egenart og deres indsats". Som fremhævet af Hjalmar Helweg beholdt bevidsthedslivet sin retning, dog med tilbøjelighed til at flyde ud over "sine normale bredder" - og Høirup tillægger, at produktiviteten var "rivende", også under sygdommen. Skønt meget fra Frederiksdal-opholdet vel er tilintetgjort, foreligger et par tusind vanskeligt læselige foliosider med digte og epigramagtige rimerier, og endda fik han en digtkreds fra hånden: "Høinordens Rimkrønike" (110 sider i PS IX, udg. 1930). ${ }^{12}$

11 Jf. E. Brandt Nielsen, "Peter Nikolaj Skougaard, Grundtvigs mathematiske ven" (GrSt 1966).

12 Jf. Anders Eskedals artikel i GrSt 2003 om, hvordan Grundtvig var som præst efter sygefraværet, hvor jo menigheden havde anmodet ham om at trække den indsendte afskedsansøgning tilbage. - Næppe ganske tilfældigt efterfølges Eskedals artiklel af Edmund Gosses skildring af sin oplevelse af 
Straks efter Grundtvigs død kom det til en strid mellem arvingerne om rådighedsretten over hans efterladte papirer. Steen Johansen har i GrSt 1968 offentliggjort en af Svend Grundtvig forfattet beretning (samt en del breve sagen vedrørende) med tilføjede bemærkninger om den mindelige, men restriktive afgørelses betydning for hans udgivelsesvirksomhed. ${ }^{13}$

\section{Den idehistoriske linje}

C. I. Scharlings afhandling om Grundtvig og romantikken belyst ved hans forhold til Schelling forelå i korrektur hin nat i Ribe Bispegård, et faktum, der fik øjeblikkelig indflydelse på William Michelsens valg af disputatsemne. Han anmeldte skriftet grundigt og sympatisk i $\mathrm{GrSt}$ 1948 med afsæt i den tanke, at isolation i samtiden (usamtidighed) meget vel kan lede til betydning for eftertiden. Grundtvig distancerede sig efter 1810 fra romantikkens livssyn, men ifølge Scharlings læsning af en række Danne-Virke-artiker ikke fra dens poesisyn - uden at han dog ifølge Michelsen får kortlagt forholdet mellem Grundtvigs og romantikkens poetik tilstrækkelig grundigt. Anmeldelsens pointe er, at Grundtvig opfattede sig som romantisk forfatter 1805-10, det vil sige så længe han mente sig $\mathrm{i}$ stand til at forene synet på poesiens "evighed" med kristendommen - og i øvrigt satte han i disse år ikke skel mellem poetik og livssyn. Den schellingske helhedstænkning, der jo ligger bag Grundtvigs asalære-fremstilling, overføres i optrinene af kæmpelivets undergang på historien.

Forløbet herfra og frem finder Michelsen mindre tilfredsstillende belyst: "Hele forholdet kræver en grundigere undersøgelse" - den nemlig, som han selv bidrog til med disputatsen om tilblivelsen af Grundtvigs historiesyn (1954) og supplementet om "den sælsomme forvandling" i digterens liv (1956). Historiesynet vises at have rødder i den samtidige, i faderens bibliotek bredt repræsenterede historieskrivning, men fik spirekraft især fra de romantiske historiefilosoffer, først fra Steffens, kraftigst fra Herder, der førte Grundtvig "tilbage til Luther og Bibelen". Villiam Grønbæk glæder sig i sine anmeldelser ( $\mathrm{GrSt}$ 1955 og 1956) over en tungtvejende behandling allerede i afsnittet om barndomslæsningen af mødet med Luthers tanker, blandt andet om

Grundtvig som Vartov-præst, få uger før han døde (meddelt af S. A. J. Bradley).

13 Ligeledes i GrSt 1968 offentliggjorde Steen Johansen artiklen "Hvorledes kom Grundtvig til at oversætte Saxo og Snorre?". Danmarkshistorien fremgik af "en indre tilskyndelse", kongesagaerne af "en opfordring udefra". I begge tilfælde arbejdede han "med Lyst og Glæde", og jo således at resultatet blev "værker af Grundtvig". 
gudbilledligheden. "Og det er altså en litteraturhistoriker, der har givet os en så grundig redegørelse for forholdet mellem Luther og Grundtvig”. Knap så interessant forekommer ham supplementet, der sammenholder disputatsens opfattelse med, hvad periodens øvrige værker og papirer lader sig forlyde med - skønt den "lader os se ind i en fornem og højt begavet forskers værksted" under arbejdets fremadskriden.

Også Henning Høirups disputats, skriftrækkens første bind, om Grundtvigs syn på tro og erkendelse, har filosofisk-idehistorisk ærinde. Men frem for at beskæftige sig med relationer til den nyere skoles filosoffer spørger den til Grundtvigs "normalfilosofiske" udgangspunkt, den af Børge Riisbrigh formidlede sene 1700-talsfilosofi, som Grundtvig ganske vist kritiserede, men dog efter Schelling-opgøret bedømte med overbærenhed. Høirups mageløse opdagelse er, at "modsigelsens grundsætning" kom til at indtage en central plads i Grundtvigs argumentation specielt for den kirkelige anskuelse. Grundsætningen - i C. I. Scharlings anmeldelse (GrSt 1949) sammenfattet således: "intet, der modsiger sig selv, kan være sandt, medens det, man ikke kan nægte uden at modsige sig selv, maa være sandt" - danner basis for argumentationen både i Kirkens Gienmoele og i den videre udfoldelse af Grundtvigs kristelige erkendelse, hvis bundethed til erfaringen, historien og åbenbaringen disputatsen gør detaljeret rede for.

I GrSt 2000 foretager Erik Kelstrup en filosofisk belysning af Grundtvigs anvendelse af modsigelsens grundsætning i Kirkens Gienmaele. Hvor Henning Høirup mener, at kontradiktionsprincippet er "det teologiske aksiom hvorudfra opgøret med Clausen finder sted", problematiserer Kelstrup dette, ikke mindst hvad angår "skriftets overordnede argumentation". Gennem genmælet løber to argumentationskæder. Grundtvig vil med vold og magt, og jo altså på kirkens vegne, fælde den rationalistiske kirkelærer på hans selvmodsigelser samt påvise, at han på kættersk vis kolporterede en falsk lære. Konklusionen bliver da, at Grundtvig bruger grundsætningen formalt, uden ontologiske komplikationer (altså à la Kant, som Høirup noterede, at Grundtvig var ude i et erkendelsesteoretisk opgør med, ikke à la Wolff, der netop opfattede grundsætningen som en ontologisk lov), samt at brugen i realiteten er overflødig, således som det indirekte fremgår af, at "en simpel argumentationsform" mere og mere tager over og bringer tingene på plads - det egentlige aksiom er Grundtvigs kirkelige anskuelse.

Også Sigurd Aarnes' disputats Historieskrivning og livssyn hos Grundtvig (1961) er overvejende idehistorisk anlagt. William Michelsens grundige opposition (GrSt 1962) fastslår afslutningsvis, at doktoranden med inddragelse af et meget omfattende arkivmateriale og fra et strukturalistisk synspunkt har løst den opgave, han selv gerne havde 
løst fra et historisk-genetisk: "at karakterisere de tre stadier i udviklingen af Grundtvigs livssyn, der repræsenteres af hans tre Verdenskrøniker". Undersøgelsen gælder toverdenmotivet, forestillingen om "virkelighetens tvedeling i en åndelig og [en] legemlig verden" - som ganske vist først bliver til to, når døden "gjør Skjel imellem Støv og Aand". Et centralt punkt hos Michelsen er, at Grundtvigs tænkning efter 1810krisen "indordnes i en kristen livsanskuelse, der tydeligt kan adskilles fra den romantisk prægede almenreligiøsitet", som karakteriserede årene 1805-10. Aarnes derimod giver i medfør af sin metode ikke svar på, om det er "den bibelske eller den romantiske opfattelse" af todeltheden, der dominerer - uanset at han "i praksis" ofte giver udtryk derfor og følger Michelsen i, at Grundtvig indså, hvilke "farlige konsekvenser" den romantiske idealisme kunne føre ud i. Just derfor kunne Grundtvig tjene Michelsen som bolværk mod nazismen.

I GrSt 1965 gør Sigurd Aarnes status over forskningen i Grundtvigs historieskrivning, der jo udfoldede sig som fortcelling på tværs af samtidens faglige idealer. Petitessenøjagtigheden overlod han til de "grundige" historikere, af hvilke Laurits Engelstoft formulerede afvisningen, da han i 1815 søgte lærestol i København. På hvilket grundlag kan han da stadig påkalde sig interesse? William Michelsen læste Verdenskrønikerne som kulturkritiske skrifter, selv læste han dem metodologisk: hvordan kan et livssyn strukturere en historieskrivning? Aarnes finder det i øvrigt oplagt at forske videre ad det spor, som Scharling og Thaning har udstukket: om der fra midt i 1820'erne sker en genromantisering - om grænsen mellem "romantisk" og "kristent" måske er blevet trukket for stærkt op, blandt andet ud fra for upræcise kriterier. Dette kunne overvejes $\mathrm{i}$ forbindelse med en indgående undersøgelse af Haandbog $i$ Verdens-Historien. Blandt de interessante punkter nævnes synet på middelalderen som "den ny Skabelse" og angelsakserne som formidlere mellem Middelhavskulturerne og Østersøkulturerne. Som et andet felt nævner Aarnes de historiske værkers virkning på langt sigt i dansk folkelig historieformidling. Skylder vi Grundtvig "det danske folks historiske myter"?

Striden mellem Grundtvig og H. C. Ørsted i 1814-15 skildres af Erland Jessen (GrSt 1971). Romantikerne - specielt Schelling og i hans kølvand Steffens - eftersøgte et fikspunkt, ud fra hvilket kaos lod sig opfatte som et kosmos eller en universalitet. Ørsted skelnede mellem den sanselige virkelighed og en rigtigere, "fornuftsvirkeligheden". I forbindelse med Verdenskrønikens fremkomst tilskrev han Grundtvig "Fornuftsfjendskab". Starten gik for alvor med hans Imod den store Anklager. Jessen leverer en detaljeret, fint afbalanceret gennemgang af kontroversen, med henblik især på forståelsen af Schelling (som Ørsted trods reservationer forsvarede mod de grundtvigske beskyldninger 
for løgnagtighed osv.) og synet på naturvidenskaberne (som Ørsted tillagde relativ selvstændighed, mens Grundtvig fordrede deres ubetingede underkastelse).

Hos litteraturhistorikeren William Michelsen formælede studiet af Grundtvigs historiesyn - med dens forholden sig til spændingen mellem den romantisk-idealistiske humanisme og kristendommen - sig med en personligt tilegnet kristendom. Bag Michelsens undersøgelse af Grundtvigs historiesyn, som jo udformes efter 1810, ligger som noget aldeles grundlæggende "kristendommens tale om menneskets syndighed, der mødes med Guds tilgivelse". Det gjorde ham til, hvad Kim Arne Pedersen kalder "en kristen humanist". Dette på baggrund af en personlig rodfæstethed $i$ en kristen tradition og et nært kendskab til den idealistiske tradition, som Grundtvig efter 1810 gjorde op med, på vej tilbage mod en klassisk luthersk kristendom.

I GrSt 1955 leverer Michelsen en minutiøst refererende gennemgang af Grundtvigs mærkelige, kulturpsykologiske skrift om Europa, Frankrig og Napoleon (udgivet 1815, efter kejserens tilbagekomst fra Elba, men før nederlaget ved Waterloo). Han ser bogen som "en studie over åndelig herskelyst" - og Napoleon griber (som diverse forgængere) sagen an uden om religionen og må følgelig kuldsejle. De Herderinspirerede overvejelser over folkekaraktererne, som blandt andet implicerer den noget bizarre identifikation af det danske hjertefolk som efterkommere af Jafet-sønnen Javan, løber ud i en bestemmelse af naturfilosofien som en djævelsk forblændelse (og i kombination med de franske revolutionstanker som en overmåde farlig cocktail). Michelsen taler om "en usædvanlig klarhed" i denne kritik af den dominerende samtidsfilosofi - netop på overgangen til "forstandsperioden" i Grundtvigs forfatterskab. ${ }^{14}$

William Michelsen inddrager i sine idehistoriske bemærkninger om Grundtvigs tidsopfattelse (GrSt 1976) også Kierkegaards, det vil sige den filosoferende samtids gængse opfattelse af tiden som uendelig. Grundtvig, der højst én gang i sit liv foretog et "tankespring", nemlig det "ud af den idealistiske filosofi" i 1813, holdt sig til den dyrekøbte erfaring af tiden som knapt tilmålt, udspændt mellem fødsel og død, skabelse og dommedag.

\footnotetext{
14 Jf. til de sprogbetragtninger, som også indgår i Grundtvigs kulturpsykologiske udredning, Horst Nägeles bidrag i GrSt 1971 om “ægte Tydsk” og om det tyske "Hjertesprog" i Grundtvigs forestillingsverden. Jf. også Inga Meinckes "skyggerids" "Schiffbruch und Erlösung" i GrSt 1996 om forsøget på at etablere "en Klippe- $\varnothing$ i Fortolknings-Havet", et sæt strategier, der burde kunne afværge kritikken fra oplysningsside mod hans absolutistiske tolkning af den franske revolution.
} 
GrSt 1979 bragte nogle overvejelser af Michelsen om Grundtvigs forhold til samtidens tænkemåde. Hovedproblemet var jo relationen mellem tro og viden, med Grundtvigs udtryk: mellem kirke og skole. Som bekendt lærte han at "skelne skarpt" omkring 1832 - modsat samtiden. Artiklen trækker hovedlinjer og almene forudsætninger op og fungerer som optakt til en dyberegående, mere systematisk anlagt analyse ved Henrik Fibæk Jensen af Grundtvigs erkendelsesteori på grundlag af en række Danne-Virke-artikler, de "filosofiske". Udgangspunktet tages i en dagbogsført 1804-oplevelse af at stirre ned i forgængelighedens og meningsløshedens afgrund, svarende til den, som Kierkegaard beretter om i Frygt og Baven. Grundtvig lader tiden, historien altså, være overordnet "både menneskelig spekulation og bibelfortolkning og derfor alle tings prøve". Danne-Virke-afhandlingerne forsøger at etablere et filosofisk underlag for, hvad hans følelse for så vidt vidste - at overtale forstanden, så at sige. Skønt meget bevendt blev denne jo aldrig. Den "løb Sur, da den løb Panden mod Kirkemuren", og til at "avle det evige Livs glade Vished i Hjertet" rækker den ikke, det er troens sag.

Til de "filosofiske" Danne-Virke-artikler hører "Om Mennesket i Verden", genudgivet i 200-året af Knud Bjarne Gjesing. Dens væsentlighed er flere gange blevet fremhævet i bidrag til GrSt, men især i en artikelsamling redigeret af Ove Korsgaard (1997), som Henning Eichberg har kommenteret i et bidrag til GrSt 1998, "Modernitetens modsigelser". Skønt nok lidt overset i receptionen opfatter Eichberg det som en nøgle til forståelse af Grundtvigs filosofi og psykologi og stiller skarpt på dets "modsigende sproglige, metaforiske og billedmæssige mønstre", der ofte udsiger andet, end ophavsmanden intenderede. Hvad udsiger nu modsigelserne, og hvad kan vi bruge dem til? Diskursens dualistisk konfigurerede orden producerer en ikke-intenderet uorden, og en række triadiske strukturer og spændinger komplicerer sagen yderligere. I triaden legeme/ånd/sjæl peger ånden udefter mod samvær og samfund, bort fra den naturvidenskabelige bestemmelse af mennesket. Når artikelsamlingen har fået titel efter artiklens motto, En orm en gud, "bliver konfigurationen ført tilbage til det dualistiske, som Grundtvig netop prøvede at overvinde", bort altså fra det samfundsmæssige og fra perspektivet henimod det folkelige og en teori om dette. Skriftet er således ifølge Eichberg blandt andet et udkast til, "hvad senere blev historisk virksomt som Grundtvigs folkelige anarkisme".

"Antropologi og poetik i Verdens Krønike 1814" er titlen på et bidrag af Knud Sølvbjerg (GrSt 1982). Grundtvig ser det i tid og rum indsatte menneske som en trefoldighed af legeme, sjæl og ånd, "skikket til Følelse, Erkiendelse og Forestilling", og udstyret med fri vilje 
og med en samvittighed, der regulerer kursen, når det "handler, skriver historie, filosoferer og digter". Analogt med det enkelte menneskes udvikling forløber folkeslagenes og menneskeslægtens. Og analogt med opfyldelsen af profetierne skabes poetikken - det dunkle vil med tiden blive klart, om digteren ellers holder sig på sin rette vej. Poesi er således "åndelige ord, der udtrykker et guddommeligt sandt åndeligt forhold". 15

I GrSt 1991 gør Kim Arne Pedersen rede for sine hermeneutiske overvejelser i forbindelse med afhandlingerne i Danne-Virke - i kritisk dialog med William Michelsens i hovedsagen idehistorisk orienterede afhandlinger i GrSt 1972 ff., hvis pointe er, at det erkendende menneske "ikke kan gå ud over det punkt i historien, hvor det er placeret", samt at Grundtvigs tænkning er "væsentlig forskellig fra samtidens" og for så vidt begribelig " $i$ analogi med Søren Kierkegaards opgør med den tyske idealismes spekulativt funderede systembyggeri". Denne bloktænkning finder Pedersen langthen ufrugtbar. Han fokuserer på Grundtvigs filosofiske terminologi og de tilknyttede indholdsmæssige forestillinger, på filosofilæsningens betydning for udformningen af Grundtvigs egen tænkning og kritik, samt på samspillet mellem spekulativt-metafysiske motiver og programerklæringer/overvejelser og skitserer sine konklusioner - blandt andet er det i almindelighed betænkeligt at adskille tro og viden så klart, som Michelsen gør det, og at opfatte Danne-Virke og den samtidige version af Verdens Krønike "som skarpt adskilte størrelser med henholdsvis alternativ til og kritik af filosofien". 16

Synnøve Heggems bidrag til GrSt 2007, "Mennesket i verden som brud", er baseret på disputatsen Kjcerlighetens makt, maskerade og mosaikk (2005), en læsning især af Sangværket - og ikke baseret på de filosofiske redegørelser, som for eksempel den i Danne-Virke 1817, men på menneskesynets manifestationer rundt omkring i teksterne. Det androgyne menneske, "helheden af mand og kvinde", er et ideal. I bryllupssituationen realiseres helhedsbestræbelsen. Grundtvigs brudebilleder forholder sig til og videreudvikler den mystiske traditions, velkendt fra Brorson. Sammenstillingen af Freja og Kristus som ægtepar, og identifikationen af Freja med Danmark eller menigheden, er en påfaldende variant af bruderetorikken, der i det hele taget er "et oppsiktsvekkende teologisk argument for hva kroppen betyr i alle former for kjærlighet". Funderingerne fører videre til anerkendelse af kvinden som skikket til "at tage Del i Embedsgjerningen", hvad der i

\footnotetext{
15 Knud Sølvbjergs artikel stammer fra et speciale skrevet før Helge Grells 1980-afhandling.

16 Jf. William Michelsen, "Om Grundtvig-debatten med svar til mine kritikere" (GrSt 1992).
} 
tiden jo var næsten utænkeligt. Grundtvigs "store fortjeneste" er, at han "reflekterer en kjønnet tale i kristendommens dogmatikk og ekklesiologi".

Disse overvejelser er foregrebet $i$ to ligeledes kvindelige forskeres bidrag til GrSt 1991. Kirsti Aasen gør opmærksom på Grundtvigs forestilling om livets dobbeltnatur ("helt kun i Mand og Kvinde"), hvor ganske vist forstandighed og hjertelighed fordeles traditionelt, men hvor den kvindelige "lettroenhed" værdsættes højt. ${ }^{17}$ Og Kirsten Ditlevsen skitserer på basis af prædikenerne Grundtvigs syn på den jo ellers af reformatorerne sortlistede Jomfru Maria, der som modstykke til Eva bliver garant for Jesu menneskelighed, kristent forbillede, åndelig kraft og billede på troen og kærligheden. Synspunktet - aktualiseret måske af Mathilde Fibiger og Marie Toft - peger mod de østkirkelige traditioner og specielt mod Irenæus, men ikke mod papismens vamle omgang med Jomfruen.

I GrSt 2007 kan man læse Uffe Jonas' artikel "KvindeEvangeliet", der reflekterer over "Grundtvigs mandebilleder og kvindesyner" og peger på "hans gennem-erotiske livsopfattelse" som helhedsetablerende i forfatterskabet. I den "grundtvigianske beskæring" har den folkeligt-nationale patriark og profet overskygget "en række andre, mere filosofiske, subtile, poetiske, hjertelige og for så vidt også $k v i n d e l i g e$ sider af hans væsen". Hans væksttænkning suger næring inderst inde, i hjemmet med dets intime relationer, "mellem nadvergangen, salmesangen og ægtesengen”. Ægteskabsforholdet præfigurerer gudsforholdet, "erfaringerne af den himmelske kærlighed bygger direkte videre på det erotiske naturgrundlag". Som skabelsestænker befinder Grundtvig sig ikke blandt de kønsforskrækkede munke, men på en linje mellem de gammeltestamentlige visdomsbøger og den moderne kosmologi, med østkirkelig affinitet. Det erotiske er hos ham allestedsnærværende, selv treenigheden har kvindelig pendant: moderen, datteren, ægtehustruen. Kærligheden er "den opløftende og forvandlende kraft, der rækker igennem og hinsides alle kønslige, regimentale og sociale forskelligheder", ja, "hver eneste gudstjeneste er i virkeligheden en kosmisk bryllupsfest, en liturgisk-poetisk fejring af skabelsesdramaet". Det er lysten, der driver værket - men således må det ikke være for folkekirkens moderne dødbidere.

Som William Michelsens og Sigurd Aarnes' disputatser beskæftigede sig med Grundtvigs historiesyn ud fra en overvejende idehistorisk vinkel, således også Ole Vinds doktordisputats Grundtvigs historiefilosofi (1999) - som dog nok opererer med et bredere historiefilosofibegreb, hvad man ser allerede af, at Nordens Mythologi, Chri-

17 Lettroenhed - jf. Jomfru Maria, der har let ved at tro, hvad Gabriel bebuder: "Mig skee, som du har sagt!". 
stenhedens Syvstierne og Kirke-Speil inddrages på linje med den mere "regulære" historieskrivning. Også historiefilosofiens tyske bagmænd og dens virkningshistorie behandles. Aarnes noterer i sin anmeldelse i GrSt 1999, at Vind hvad angår tysk påvirkning betoner oplysningsaspektet snarere end det romantiske islæt hos de pågældende, fra Herder til Schelling.

Netop forholdet til Herder er genstand for indgående sonderinger af Johannes Adamsen i GrSt 2001. Han påpeger blandt andet, at den mageløse opdagelse var foregrebet i tidens debat. Således havde Lessing undermineret sola scriptura-princippet og påpeget, at der forud var en regula fidei, der havde styret blandt andet skriftforståelsen og kanoniseringen. Herder havde spundet videre på tråden, ligesom F. V. Reinhard, der "ikke antastede fornuften, men ved hjælp af fornuften kom til Skriften", altså sammentænkte oplysning og lutherdom. Denne såkaldte supranaturalisme udelukkede ikke "fornuftig beskæftigelse med historien". Og netop som historiker er det som bekendt, at Grundtvig lægger sig efter Herder: "Dybdestrukturen i Grundtvigs historiesyn er fuldstændig som hos Herder, at historien skal fortælles på en sådan måde, at virkende årsager, i.e. ånd, igen skal gribe og inspirere til handling på en ny tids præmisser". Men Grundtvig udgrænsede folkeslag, der ikke havde fået kontakt med kristendommen, og han lod naturen ude af betragtning. Forskellene beror på, at romantikken kom imellem. Fremskridtstanken var for eksempel afgørende for oplysningen, men ikke-konstitutiv for romantikken. Herder fastholder et modificeret fornuftsbegreb, Grundtvig lader i det store og hele fornuften sejle sin egen sø. Hvad bibelsynet angår, lancerer Adamsen bestemmelsen poetisk biblicisme (via-à-vis gængse bestemmelser af det som liberalt og Ole Vinds bestemmelse af det som fundamentalistisk). I forbindelse hermed noterer Adamsen nogle "teologiske tab". Den "frelseshistoriske konception" fører Grundtvig bort fra Herders historiefilosofi. Han "udviser en påfaldende mangel på reel udfordring fra det anderledes i historien, fra alt det som kunne have problematiseret den frelseshistoriske konception".

Kim Arne Pedersen har i "Grundtvigs natursyn" (GrSt 1989-90) foresat sig at udrede spørgsmålet om, hvordan Grundtvig egentlig stillede sig til naturen og naturvidenskaben, i hvert fald i tre "skæringspunkter". I Verdenskrøniken 1812 afvises naturvidenskaben ikke principielt, men det pointeres, at den tenderer imod at unddrage sig gudserkendelsen og befordre vantroen. I Danne-Virke tilvejebringer Grundtvig (i forlængelse af H. C. Ørsted-debatten) et metafysisk fundament for natursynet og gør gældende, at historien "bestandig er overordnet naturen" - hvis positive betydning i øvrigt erkendes gennem kærlighed til kvinden. Grundtvig arbejder med to mikro- 
kosmosforestillinger, en "rationel" og en "billedsproglig", af hvilke den første vedrører menneskets forhold til skabelsen i øvrigt, mens den anden vedrører det skabtes åndelige betydning - med Grundtvigs ord: "Naar Menneske-Livet er forklaret som en Virkning af Guds Ord, kan Verden forklares som en ligedan, idet Mennesket lærer at kiende sit Legeme som Aandens billedlige Redskab, og som en Verden i det Smaa”. Pedersen bemærker en tankeforskydning først i 1830'erne, ikke som Thaning et nybrud. Specielt knyttes jo mellem folkehistorie og naturhistorie en tæt forbindelse, som skjalden gav mytologisk iklædning, længe før historikere og naturforskere sammen kastede blikket på "de Naturforhold, hvori Mennesket som Jordbo staaer". I fornyet diskussion med Ørsted henførte den på "levende Veksel-Virkning" indstillede Grundtvig spørgsmålet om verdensbilledet til videnskabens domæne. Kopernikus kunne man befatte sig med i skolen, knap nok i kirken. Højskolen i Göteborg skulle skelne mellem historiske og fysiske videnskaber, men Pedersen finder det oplagt, at det i vekselvirkningen er de fysiske, der skal lade sig belære, siden det jo fortsat gælder, at naturen er skabt i menneskets billede og mennesket i Guds. I det videre forløb - blandt andet i salmerne bliver naturtydningen det centrale i natursynet. Over for Ørsteds Aanden i Naturen anfører Grundtvig, at den menneskelige granskning må begynde "hjemmefra", hvor naturvidenskaben begynder med det, der er længst borte - hvilken tankegang ligefrem foregriber "Antikrists falske lærdomme" og for så vidt bidrager til at kridte banen op til "den apokalyptiske endetidskamp". ${ }^{18}$

\section{Den litterære linje}

"Har Grundtvig-Selskabet forsømt digteren Grundtvig?" Det spørgsmål stillede Gustav Albeck (GrSt 1987) efter et tilbageblik på de litteraturhistoriske indsatser forud for Selskabets stiftelse. Frederik Rønning besad "en nidkær apologets ihærdighed", mens Holger Begtrup, der som udgiver var "et mønster på omhu og akribi", i for ringe grad tilgodeså den poetiske del af forfatterskabet. For Georg Brandes var Grundtvig en stor mand, som man måtte afsky, mens H. S. Vodskov fremhævede ham netop som digter, "en af vore største". I Vilhelm Andersens litteraturhistorie kommer Oehlenschläger ind på førstepladsen, dog med erkendelse af "den rige og storladne poetiske kraft" i Grundtvigs digtning, med "uforbeholden beundring" for samspillet mellem

18 Til den idehistoriske emnekreds kan også regnes Kim Arne Pedersens "Grundtvig og Geijer - to møder og en afsked" (GrSt 1996), der rapporterer fra et symposium om de to mænds indflydelse i deres respektive lande. Indlæggene er offentliggjort, jf. Gert Nilssons anmeldelse i GrSt 1998. 
det stærke og det milde i "I Kvæld blev der banket paa Helvedes Port". Linjen løber ind i Selskabets historie, for så vidt som Paul V. Rubow, der i 1937 havde efterlyst en udforskning "på videnskabelig grund" med tilskud af grundtvigiansk begejstring, i 1955 udtrykte håb om, at digteren Grundtvig ikke måtte hjemfalde "til Theologien og Kirken". En bestræbelse i den retning var jo kommet i gang, før Hal Koch blæste til samling om Grundtvig. Det ideale samarbejde blev praktiseret $i$ forbindelse med udarbejdelsen af den store registrant, bragt til verden ligesom udgaven af dag- og udtogsbøgerne i samarbejde med Det danske Sprog- og Litteraturselskab. Generende forekommer det Albeck, at der har kunnet skaffes penge til en prædikenudgave, men ikke til en brevudgave, samt at jubilæumspublikationen fra 1983 "i nogen måde har forpasset en oplagt lejlighed til at overbevise udlandet om, at en af Danmarks største digtere hedder N. F. S. Grundtvig”. Til gengæld bragte året jo Poul Borums ord herfor; fra den i det følgende skitserede tradition citerer han ikke mindst Flemming Lundgreen-Nielsens disputats "med jublende tilslutning".

Ganske rigtigt kan der blandt de mange udgivelser til 200-årsjubilæet i 1983 være grund til at standse op ved Borums veloplagte Digteren Grundtvig, anmeldt sympatisk-kritisk af Finn Stein Larsen (GrSt 1984), der finder det "lovende og spændende", at en modernistisk lyriker og usekterisk kritiker ser salmisten an. Han peger da også straks på Borums kapitler om "Nyaars-Morgen" og salmerne. Borums abstrakt formulerede billedsprogsdefinition ("at vi allerede, når vi siger noget, samtidig siger noget andet, nemlig et fravær og et skjult nærvær") indfanger fint Grundtvigs altid meget konkrete billeder. Billedsproget "udgør et mageløst forråd af elementær synssansning, genkendelige kropsrørelser og fortrolige rum for den, der kan nemme det". Borum påviser parallelløb mellem "selvgyldig og oprindelig navngivning" og "kompliceret betydningsfylde". I andre dele af bogen går det desværre gruelig galt, den er "alt for tidligt taget rødglødende af essen og overladt til trykken".

\section{Gustav Albeck}

Det for Gustav Albeck særegne var som nævnt hans insisteren på, at Grundtvig var en betydelig digter (jf. William Michelsens nekrolog, GrSt 1995). Allerede hans bidrag til GrSt 1948 understreger dette. Talen er om en afprøvning af Sigurd Müllers tese om, at indskriften på Oddens Mindestøtte snarere end en "genial Improvisation" er frugten af "lige saa megen Omhu som Geni", altså af formvilje. At Grundtvig selv efter 1810-krisen noterede, "at Gud som stedse skulde ihukommes", glimrede ved sit fravær, er en anden sag, men ytringen er af den slags, "der har faaet mange til at tro, at Grundtvig lod haant om Form- 
kunsten og blot bedømte et Digterværk efter Styrken af dets kristelige Forkyndelse". Artiklen eksemplificerer udmærket, hvorledes manuskriptstudier i Grundtvig-Arkivet kan anfægte vaneforestillinger om Grundtvigs måde at digte på.

I stor skala forfølger Albeck sit synspunkt i Omkring Grundtvigs Digtsamlinger (1955), der diskuterer og opvurderer den verdslige lyrik frem mod 1816, og langthen med fokus på forholdet til Norge, hvor han jo forsøgte at blive historieprofessor ved det nye universitet, og hvor han i øvrigt gjorde plads for Åbenbaringsbogens sjette menighed (der dog senere tilfaldt Danmark). ${ }^{19}$ Herudover hæfter Morten Borup sig i sin anmeldelse (GrSt 1956) ved Grundtvigs beundring for Jens Baggesen, hvis parti han jo tog i tylvtefejden mod Oehlenschläger og dennes unge tilhængere.

Til bogen knytter sig en tekstkritisk undersøgelse (GrSt 1954) af de genetisk beslægtede digte "Strandbakken ved Egeløkke" og "Havet". Albeck vil grave dybere end forgængerne og komme til "et sandere, mere nuanceret Syn" på Egeløkke-digtets udviklingshistorie og tilvejebringe entydighed vedrørende dets tre foreliggende tilløb og den endelige form, der jo indarbejder erfaringen af 1810-krisen. Nyt i 1811 er - ud over visse holdningsmarkeringer (vismændene erholder for eksempel ret $i$, at skønheden er giftbefængt) - midterafsnittet med "et biografisk Stof, der er velegnet til Gymnasieundervisning" (!), og med "menneskeligt gribende Bekendelser og Passager af stor kunstnerisk Skønhed".

I GrSt 1968 beskæftiger Albeck sig med Grundtvigs forhold til Jylland, nærmest en motivstudie, hvor udgangspunktet er, at i hvert fald ynglingen "vist nok i uhyggelig grad" fattedes natursans. Til gengæld bliver halvøen - i forbindelse med det netop tabte Norge - tillagt en betydelig rolle i historien, især i Et Blad af Jyllands Rimkrønike, hvor Saxo-stof sammenvæves med profetisk vision. Herfra trækkes linjen til, hvad han i 1840'erne ytrede på Skamlingsbanken og om Slesvig.

19 Jf. Gustav Albeck, "Den unge Grundtvig og Norge" (GrSt 1985), der indledningsvis pointerer, at Grundtvigs fædrelandskærlighed (som Oehlenschlägers - og mange andres) gjaldt dobbeltmonarkiet, men i øvrigt især vedrørte hans forhold til nordmændene Svend Hersleb, Frederik Schmidt, Niels Treschow, Georg Sverdrup og Stener Stenersen før Kielerfreden. Som bekendt prøvede de at få Grundtvig til at søge historieprofessoratet ved det nye Christiania-universitet, hvilket man især fra dansk side misbilligede formedelst subjektivismen $i$ hans fortolkninger af verdenshistorien og navnlig af samtiden. - Jf. også Sigurd Aarnes, "Grundtvig og Norge - noen hovedlinjer" (GrSt 1993), der mest vedrører virkningshistorien. 


\section{Helge Toldberg}

Helge Toldbergs disputats Grundtvigs symbolverden baserer sig på en forestilling om symbolers egenværdi som konstitueret så at sige på langs gennem forfatterskabets tekster (fra Et Blad af Jyllands Rimkrønike og frem), med "afledt" betydning naturligvis for tolkningen af enkeltteksterne, en opfattelse, som Ejnar Thomsen i sin anmeldelse ( $\mathrm{GrSt}$ 1952) viger tilbage fra "at acceptere i dens absoluthed"; han noterer, at Toldbergs "metode og målsætning rent litteraturvidenskabeligt er farlige i deres fornægtelse af det isolerede enkeltværks organiske lilleverden", ligesom han anholder forekomsten af "ejendommelige dogmer om hvad for genrebåse og strukturrammer den og den substans er skabt for". Han glæder sig på den anden side over, at Toldbergs forskning placerer sig i feltet mellem substrat (i Grundtvigs tilfælde "det existentialreligiøse") og struktur - men ikke over hans adskillelse mellem "de substratbestemte livs- og trossymboler og de af substratet væsentlig uafhængige sagn- og traditionssymboler, hentet fra mytologi og historie".

Til GrSt 1954 har Toldberg bidraget med en større artikel om Grundtvigs "rimkrønikesysler". Indledt til trøst efter den nedslående Kielerfred forløb de "fra et filologisk standpunkt til et suverænt digterisk", med 1826 som vendepunkt, og med den af Beowulf inspirerede tilføjelse af Kong Skjold-myten i 1826- og 1834-bearbejdelserne som kunstnerisk højdepunkt. Som videnskabeligt udbytte kan især noteres selve genoplivelsen af interessen for skriftet, den første på dansk trykte bog, af Grundtvig betragtet som folkelig Bibel (og angiveligt læst af ham oftere end den rigtige Bibel). Han bliver dog på ét punkt inden for den middelaldertradition, der tilbageførte fyrsteslægter til Jafet og således sikrede historien en art bibelsk legitimitet! ${ }^{20}$

Atter en stor og grundig Toldberg-afhandling er "Kirke-Klokken og andre digtninge fra 1845" (GrSt 1963). Den argumenterer - med mange måske'er - for, at salmen om klokken, der appellerer til lillebyen snarere end til hovedstaden, kan være skrevet op imod H. C. Andersens eventyr "Klokken" og med reference også til Henrik Hertz' digt "Paa Volden store Bededag". Hvad der afgørende skiller salmist og eventyrdigter, er selvfølgelig, at den usynlige klokke i "Naturens og Poesiens store Kirke" ikke er en kirkeklokke - mens udhængningen af småborgerligheden og affærdigelsen af kunstpoesien burde kunne forene dem. ${ }^{21}$

20 Jf. Gustav Albeck, der i GrSt 1960 flytter "Grundtvigs første (selvstændige) poetiske Udformning af Myten om Skjolds Komme” til efteråret 1828.

21 Jf. Karl Rønne, "Kirke-Klokken" (GrSt 1970). Symbolanalyse indebærer "fattiggørelse" men går dog an, om tekstens helhed respekteres. Så kan kirke- 
Toldberg besad, som Gustav Albeck noterede i sin nekrolog ( $\mathrm{GrSt}$ 1964), "en helt ufattelig viden og en næsten hensynsløs energi". Sidste frugt heraf var en undersøgelse (ligeledes i GrSt 1964) af "Grundtvigs sysler og interesser i første halvdel af 1831", der imødeså indsigelser (som jo kom!) mod Kaj Thanings præcise datering af den "menneskelige" nyorientering til 11. marts 1832 . Toldberg foretager flere omdateringer af Søndags-Bogen's prædikener og påpeger, at "den hjemlige litterære situations medvirkning ved Grundtvigs omsindelse" må tages i betragtning. Digteren nærmede sig igen Oehlenschläger - "venligt og ædelt", skrev denne i sin 1831-selvbiografi - og holdt lav profil, da Ingemanns Huldre-Gaverne gav anledning til en ballade med mindelser om, hvad han selv tidligere havde været indblandet i. Og så forberedte han selvfølgelig Englandsrejsen og den påtænkte udgave af angelsaksisk litteratur.

\section{Jørgen Elbek}

I GrSt 1959 fremlagde Jørgen Elbek en meget påskønnet redegørelse for Grundtvigs forhold til de latinske salmer, bearbejdet især i SangVark til den danske Kirke (1837). Undersøgelsen spænder fra det kompositoriske (bestemt af forestillingen om de syv folkemenigheder) over det kildekritiske og stilistiske til det tolkningsmæssige ("Salmernes kristendom"). Grundtvig tilstræbte, at værket kom til at rumme "indbegrebet af al kristelig forkyndelse", men de gamle (katolske) tekster må langthen have "virket som en protest mod hans poetiske følelse" - de fungerede i hvert fald overvejende som reaktionsbasis: "Tilknytningen mellem hymne og salme ligger i det uvæsentlige og kommer i stand ved omfortolkning". ${ }^{22}$ Det bør tillægges, at Elbek i 1960 offentliggjorde en tilsvarende undersøgelse i bogform vedrørende Grundtvigs omdigtninger af græske salmer, i Christian Thodbergs anmeldelse ( $\mathrm{GrSt}$ 1960) lovprist for imponerende dobbeltindsigt: i byzantinsk liturgi og hymnografi såvel som i Grundtvigs salmeunivers. Samt at Uffe Hansen allerede i GrSt 1953 diskuterede bearbejdelserne - og blandt andet pointerede, at Grundtvig ønskede enhe-

klokken "stå for salmetonen" eller, snævrere, "Grundtvigs egen holdning som salmedigter" - og Toldberg få uret $\mathrm{i}$, at digtet ikke forfølger "en bestemt plan".

22 Jf. Lars Thunberg, "Grundtvig og de latinske salmer - et teologisk perspektiv" (GrSt 1992), der gør holdt ved integrationens omkostning (gendigtningen skal føre hymnerne ind i, hvad Elbek kalder "den nutidige danske menigheds entonige lovsang"), samt ved de teologiske eller temperamentsmæssige tillempninger, som uvægerligt sker. 
den med den græske kirke etableret ved, at den udskiftede sin nikænske trosbekendelse med den apostolske. ${ }^{23}$

Gudelivet i Valhal optog som bekendt Grundtvig, ikke blot i den mytologiske periode, men livslangt. I en af Marielyst-talerne foranstalter han et tredobbelt bryllup mellem "Hoved og Hjerte, Folk og Fæderneland, Folkemunden og Billedsproget” og sætter gudenavne på. Jørgen Elbek citerer stedet i "Mytologen Grundtvig" (GrSt 1983), hvor de indremenneskelige forholds triadiske strukturering ved nordisk-mytologisk hjælp følges gennem levnedsløbets tre faser (fantasi, følelse, forstand) og med udblik på de nordiske trillingefolks historie. En overgang efter 1832 dog med forsøg på at inddrage græsk mytologi, måske - som Kaj Thaning skal have ment - som en cadeau til sibyllen Clara Bolton. $^{24}$

Digtet "Nyaars-Morgen" blev i GrSt 1964 analyseret af Elbek med udgangspunkt i en Paul la Cour-refleksion over billedet af det "staaende Korn", der er blevet "frigjort til større Liv af det skabende Ord". Elbek søger en anden læsemåde end Holger Begtrups bekendte personhistoriske - og når frem til den via Grundtvigs overvejelser om billedsprog som "Kundgiørelse af noget Hemmeligt", noget, der kun kan udtrykkes på just dén måde, på mytisk vis. De nordiske myter og skjaldens levned er "jævnbyrdige nedfældninger af den samme historie", dog med den komplikation, at den mytiske livsfremstilling "dubleres" med en personalhistorisk i 6.-9. sang. ${ }^{25}$

23 Jf. til denne problematik Else Kragelund Holts eksegetiske overvejelse, "Stat op i Gry, min Gud!" (GrSt 1996), af forholdet mellem tre Davidssalmer i Grundtvigs gendigtning og i deres form i den hebraiske bibel, altså bagom den af Grundtvig benyttede oversættelse i Christian VI's Bibel. Artiklens note 2 lader forstå, at der i realiteten sammenlignes med "en moderne, videnskabelig oversættelse"! Grundtvig synes at gendigte og omtolke den gammeltestamentlige poesi inden for traditionen, altså "som en profetisk forudgribelse af evangeliet".

24 Jf. Kaj Thaning, "Hvem var Clara?" (GrSt 1985). Grundtvig mødte Clara Bolton én gang, 24. juni 1830. Artiklen udreder Mrs. Boltons forhold til Benjamin Disraeli og bestrider flere biografers omtale af hende som den ambitiøse politikers elskerinde. Hun spillede en rolle i hans valgkampagner og kaldes i hans dagbog "a decoy duck". Elskerinderollen tilkom veninden Henrietta Sykes. Forelsket i Clara var derimod præsten Alexander d'Arblay, søn af forfatterinden Fanny Burney. Clara døde 29. juni 1839, 35 år gammel. 25 Jørgen Elbek har offentliggjort flere artikler og foredrag, for eksempel "Grundtvig i europæisk åndsliv" (GrSt 1980), "Grundtvigs salmer før Luther" (GrSt 1981) og "Mytologen Grundtvig" (GrSt 1983). De er alle optrykt i småskrifter fra hans hånd. 


\section{Flemming Lundgreen-Nielsen}

Trods Grundtvig-Selskabets proklamerede "tværfaglighed" hænder det, at modsætninger gør sig bemærket. Lundgreen-Nielsens disputats Det handlende ord - om Grundtvigs digtning, litteraturkritik og poetik i årene 1798-1819 - blev i Christian Thodbergs opposition (GrSt 1982) karakteriseret som "en imponerende videnskabelig indsats", men også kritiseret især for at påberåbe sig fuldstændighed og basere sig på "samtlige papirer" (svarende til, at den vil være en håndbog). Den litterærhistoriske betragtning føres ikke over på prædikenerne, skønt Grundtvigs poetik og billedsprog dér kommer til praktisk udfoldelse, så de bygger bro til den senere salmedigtning. Specielt i de "højstemte" (euforiske) perioder kan dele af prædikenerne "udskrives som prosadigte". I øvrigt konkretiseres tesen vedrørende Grundtvigs "forståelse af sig selv som symbol på den kommende fornyelse i Norden" ikke før til sidst $\mathrm{i}$ afhandlingen ${ }^{26}$ - som Henning Høirup et sted har kaldt "en forskningens dreadnought".

I GrSt 1982 findes et bidrag af Lundgreen-Nielsen om, hvordan Grundtvig i den første tid på Valkendorfs Kollegium gjorde sig bekendt med ny digtning via læsekredsen "Det litterære Selskab", som i øvigt lod enkelte af hans udgivelser fra de følgende år indkøbe.

"Rød og hvid i Billedsalen" er titlen på Lundgreen-Nielsens gennemgang (GrSt 1980 og 1981) af seks af Grundtvigs døds- og mindedigte, et ganske omfattende bidrag, hvori de pågældende tekster - tre digte fra 1820'erne (moderen, mæcenen grev DanneskioldSamsøe og den lidt ældre digterkollega Jens Baggesen) og tre fra 1840'erne (fætteren Henrich Steffens, billedhuggeren Bertel Thorvaldsen og ungdomsvennen Povel Dons) - gengives. De transcenderer 1700-tallets tankelyrik på området "ved at tilsætte anelsesfulde mangetydige romantiske symboler og at instrumentere sproget romantisk med vokalklange, inversioner, gentagelser og arkaismer", hvilket tekstgennemgangene fortrinligt dokumenterer. Titelcitatet opfordrer den efter langvarig sindssygdom afdøde ungdomsven til at genopstå "med farve af liv og evighed i moderne åndshistorisk mytologi". I det romantiske gennembrudsår slog "Lynilds-Sæden" ned - Zeus' "befrugtende lynstråle", antyder Lundgreen-Nielsen, men hvorfor ikke Steffens' forkyndelse af budskabet, for digtet til hans minde karak-

26 Pudsigt nok fremgår det ikke, at Lundgreen-Nielsen er disputatsens ophavsmand - end ikke af den redaktionelle anretning af oppositionen. - I øvrigt blev Lundgreen-Nielsens første større Grundtvig-afhandling, om skæbne og forsyn i den nordisk-romantiske dramatik, anmeldt meget positivt af William Michelsen (GrSt 1966); den gør Grundtvig "levende og nærværende" og baserer sin kritik på "en loyal og klar fremstilling" af hans poetik. 
teriserer ham jo netop som "Lynildsmand". Den kernedanske Grundtvig kunne i øvrigt ikke se bort fra, at både Steffens og Baggesen havde ført sig frem også som tyske forfattere. Absolutionen til Steffens begrundes med, at tungen og ånden ("dem det er, som skifte Arv") tilhørte Danmark, mens Baggesen ligefrem spaltes i tvende parter, "en tysk-patetisk overmodig" og "en dansk-lunefyldt barnlig", hvor kun de runer, som "vor Moder risted med din Pen", falder i den gode jord.

"Grundtvigs nordisk-mytologiske billedsprog - et mislykket eksperiment?" er emnet for en større fremstilling af Lundgreen-Nielsen i GrSt 1994. Tilegnelsen frem mod 1810 har en lidenskabelig-videnskabelig karakter, mens efter 1815 mytologiens "aktuelle udtryksmuligheder sættes over dens oprindelige mening". Mytologien "frisættes". Fra de tidlige 1820 'ere stammer nogle manuskriptfragmenter, der tillægger mytologien "poetisk Brugbarhed", i og med at der findes en nordisk folkeånd, hvis "uvilkaarlige og derfor nødvendige Yttring" netop er poesien. Men først i 1832 kommer han "som mytologisk forsker og formidler" ud af dødvandet, med ned- og opture frem mod midten af århundredet, også i den digteriske praksis, og alt sammen i forsøget på at genoplive "Nordens historisk-poetiske sindbilledsprog" som fællesskabskonstituerende. Det er dette projekt, som efter Lundgreen-Nielsens opfattelse mislykkes, hvilket Grundtvig vist i stigende grad erkendte. Den afsluttende "havariopgørelse" peger på flere årsager (den romantiske individualisme- og originalitetsorientering, den antikke traditions sejlivethed, den tiltagende sans for nutidig hverdagvirkelighed, osv.). ${ }^{27}$

Under overskriften "Grundtvig og guldalderens København" orienterer Lundgreen-Nielsen i GrSt 1995 indledningsvis om Grundtvigs faktiske, stærkt begrænsede deltagelse i hovedstadsborgerskabets traditionelle kulturmanifestationer og om, hvordan han efterhånden fik status, ja, "i stigende grad selv [blev] en københavnsk seværdighed". Ellers drejer det sig om hans tempererede opfattelse af de kunstneriske discipliner og forhold til deres udøvere (for eksempel agtede han Thorvaldsen og foragtede hans værker) - samt om selve det fortidsvendte guldalderbegreb og det fremtidsvendte gyldenårsbegreb. Gyldenåret er i reglen "snarligt kommende", som i kongerøgelsesdigtet "GyldenAaret", om 1834, og i "Danmarks Guld-Alder og Gylden-Aar", om afdøde Frederik VII's regeringstid og, midt i sorgen, forventningen om en lys, jævn, munter og virksom fremtid. Efter Lundgreen-Nielsens opfattelse tilførte han fra sin outsider-position den på egen navle inder-

27 Jf. Jens Peter Ægidius' replik i GrSt 1996, der ikke kan give LundgreenNielsen ret i, at Grundtvigs mytologiske projekt kuldsejlede, skønt samtiden rigtignok viste sig mindre modtagelig for hans tanker. 
ligt fokuserede guldalder "de største historiske, kirkelige og religiøse dimensioner".

Lundgreen-Nielsen drøfter i GrSt 2001 meningen med en kendt passus i "De Levendes Land": "Naar Skyggen er ligest, da hulke de Smaa, / Som stirre derpaa!" Christian Thodberg har insisteret på, at "ligest" bør forstås som "mest lodret", men artiklen argumenterer for den traditionelle udlægning: "mest lignende". I denne forbindelse relateres skyggebilledet til Platons hulebillede. ${ }^{28}$

\section{Sune Auken - og Marie Louise Nyegaard}

I GrSt 2005 fremkom Thorkild C. Lybys opposition ex auditorio ved Sune Aukens forsvar af Sagas spejl (2005), hvis tværfaglige karakter undertitlen fremhæver: "Mytologi, historie og kristendom hos N. F. S. Grundtvig" - og Auken får den lov, at han på overbevisende måde behersker indfaldsvinklerne, skønt suveræniteten ligger i det tekstanalytiske. Talen er om nedslag på to vigtige punkter. For det første problematiseres Aukens i enkelte formuleringer gradbøjede begreb om gudbilledlighed. Over for denne (semipelagianske!) opfattelse sætter Lyby ordet - "det er fællespunktet mellem Gud og menneske, kontaktpunktet mellem det jordiske og det himmelske". For det andet registreres en vis løs(agtig)hed i afhandlingens kontroversielle påvisning af, at nordisk mytologi betød så meget for den unge Grundtvig, "at der ligefrem kan tales om en konflikt mellem den og kristendommen, og at dette er en væsentlig årsag til sammenbruddet i 1810”. Det berømte sted i $\mathrm{Ma}$ skeradeballet $i$ Dannemark, hvor Odin og Kristus præsenteres som "begge Sønner af Alfader", gav Grundtvig vabler i hænderne og stort dementibesvær (blandt andet $i$ "Om Afguderie", 1813). Lyby mener, at asarusen trods alt var et udbrud af religiøsitet, ikke et udtryk for religion - men dog også, at man må tage den alvorligere end som så. ${ }^{29}$

28 "Naar Skyggen er ligest"-citatet figurerer også i Niels Thomsens bidrag til samme årgang, "Grundtvig og billeder". I et brev til Ingemann medgiver Grundtvig, at "Haandens Kunstværker" kan rumme ånd, men bebrejder kollegaen, at han "lægger langt mere Voegt, end jeg kan billige, paa Aandens Spor i Bygninger, Malerier og Billedstøtter". Men reelt var han ret uinteresseret $i$ bildende kunst - og principielt mente han, at den moderne (dvs. romantiske) snak om ånd i kunsten "førte til åndløshed og afgudsdyrkelse". Artiklen omtaler også Grundtvigs poetiske billeder og gør gældende, at de er en måde at "forklare" kristendommen på. Sagen er i billederne, dogmatikken følger efter. Grundtvig har for eksempel selv sagt, at Irenæus-kærligheden begyndte med jomfrubilledet af Eva og Maria - og altså ikke med dogmatikken.

29 Disputatsen rummer "skarpsindige og åndfulde analyser" af værker fra 1808, 1815, 1824, 1832 og 1859. - To oppositionsindlæg (af Johnny Kon- 
I GrSt 1997 skriver Auken om "Hyrderne ved Bethlehem" i original version og i P. A. Fengers forkortelse af den til salmebogsbrug. Går end meget tabt, kan opstramningen resultere $\mathrm{i}$ en fuldt fungibel menighedstekst, i dette tilfælde måske med den effekt, at mødet med originalteksten efter tilegnelse af Fengers tilskæring genererer en overraskelseseffekt - sådan som Jakob Knudsen engang oplevede det. ${ }^{30}$

Aukens afhandling har været den afgørende inspiration for Marie Louise Nyegaards specialebaserede artikel i GrSt 2007 om "NyaarsMorgen". Asarusen gav kolde fødder, så da mytologien vendte tilbage til forfatterskabet, var det "som en del af den værdifulde danske arv, der peger frem mod kristendommen", som en art gammel testamente for det kristne Norden, en antropologisk foreteelse. Den fremadvendte dimension i det store digt drejer sig om en åndelig "genoprejsning" af Norden, med Grundtvig som den nye Ansgar.

\section{Det angelsaksiske spor}

Ellen Jørgensen berømmede i sit værk om 1800-tallets danske historieskrivning Grundtvig som "en Pioner i Beowulf-Forskningen". Hans indsats er for længst erkendt også af middelalderforskerne. ${ }^{31}$ Et par artikler af Andreas Haarder (GrSt 1965 og 1968) udgør forstudier til hans 1975-disputats om det angelsaksiske digt, som optog Grundtvig så stærkt, at han allerede i sin anmeldelse af Thorkelins latinske 1815oversættelse annoncerede en dansk poetisk Beowulf. Planen blev ikke realiseret til hans egen fulde tilfredshed før i 1861, men jo i 1820 foregrebet af, hvad han kun turde kalde "en Skjærv". ${ }^{32}$ Haarder relaterer

drup og Svend Skriver) er trykt i Nordica, bind 23, 2006, og to indlæg (af S. A. J. Bradley og Flemming Lundgreen-Nielsen) er ikke fremkommet på tryk.

30 I 1996 udkom Randi Rodes afhandling Barneglad og engleklog, der analyserer salmerne i Sangværkets første del, og vel at mærke med fokus på sammenhæng og udvikling. Som bemærket i Sune Aukens anmeldelse ( $\mathrm{GrSt}$ 1999) læser Rode Sangværket som en udviklingsroman, som én bog altså med 146 afsnit. Hun antager med andre ord en gennemgribende intertekstualitet. Auken lader sig imidlertid ikke overbevise om, at værket bedst bør læses på denne vis: intertekstualitetsbegrebet er ureflekteret, og referencerne er ofte tvivlsomme, hvad der jo invaliderer tesen om udvikling.

31 "Den oldengelske digtning og Grundtvig" er titlen på en artikel af Bent Noack i GrSt 1989-90, der skildrer den ganske tidligt vakte og efterhånden om sig gribende interesse for angelsaksisk litteratur (600-1066) - oversigtligt, men netop derfor god at læse før de i dette afsnit præsenterede specialundersøgelser.

32 Bjowulfs Drape, 1820. - Kemp Malone beskæftiger sig i et bidrag om Beowulf-oversættelsen (GrSt 1960) overvejende med formaliteter (metrum, rim, versbygning, afsnit, m.v.) i de præpublicerede uddrag og de tilsvarende passager i 1820-versionen, samt med oversættelsesnøjagtigheden. 
Grundtvigs opfattelse af digtets kunstneriske kvalitet til synspunkter udtrykt i nyere forskning; eller snarere: opfattelser - da den oprindelige høje vurdering i Thorkelin-anmeldelsen allerede et par år efter blev relativeret og nuanceret (digtet er ikke fuldendt, men strukturelt belastet især ved de "episoder", som er påklistret hovedhistorien). Men ved siden af den litterærkritiske betragtning anlagde Grundtvig en mytisk - og beundrede det i øvrigt i mange henseender, blandt andet som et "udmærket Oldtids-Minde". Han noterede også dets religiøse grundtone - og så drejede det sig jo for hælvtens vedkommende om danske figurer og bedrifter. ${ }^{33}$

S. A. J. Bradley, "Grundtvig, Anglo-Saxon Literature, and 'Ordets Kamp til Seier"' (GrSt 1989-90), knytter an ved Kemp Malones 1941pointering af, at Grundtvig var verdens første og største Beowulfforsker, men udvider feltet ved også at inddrage hans interesse for andre dele af den angelsaksiske litteratur. Dels gennemgår han det prospekt fra 1830, Bibliotheca Anglo-Saxonica, hvori Grundtvig efter sin anden Englandsrejse redegør for sin ambitiøse plan om at udgive en antologi af oldengelsk digtning. Og dels redegør han for Grundtvigs ønske om som skjald og historiker at anskueliggøre forbindelsen mellem "begivenhed" og "bedrift" ud fra en kristen historieopfattelse magen til Bedas i hans kirkehistorie. Endelig mener Bradley, at selve begrebet om "Ordet" bør undersøges i lyset også af den oldengelske litteratur - blandt andet med henvisning til et Danne-Virke-citat: "Ordet er, som Skriften lærer, [...] det høieste og dybeste Udtryk for Livets Aabenbarelse, og den hele Historie maa betragtes som Ordets Kamp til Seier".

Bradleys "'Stridige Stykker snild jeg forbandt': Grundtvig's creative synthesis of Anglo-Saxon sources" (GrSt 1996) peger indledningsvis på det paradoks, at den mod al livsfjern boglærdom så kritiske Grundtvig insisterede stærkt på sine forskningsfortjenester udi angelsaksisk filologi. Da han jo tydeligvis så sig som de gamle skjaldes moderne efterkommer, var indsatsen også en poetisk satsning - og gendigtningen af Phenix-Fuglen fra 1840 et symbolsk vidnesbyrd om denne poesis moderne genfødelse. Kædmon så han ligefrem som den første kristne skjald i, hvad der i hans brede opfattelse var Norden. ${ }^{34}$ Citatet om de "stridige Stykker" - fra Grundtvigs digt "Ragna-Roke" henviser til hans egen pastiche over angelsaksisk poesi, hvis brikker er udskrevet fra Beowulf og de såkaldte Kædmon-parafraser.

33 Disputatsen om det angelsaksiske digts "appeal" blev anmeldt af Jens Kruuse under overskriften "En moderne videreførelse af Grundtvigs Beowulfstudier" (GrSt 1975).

34 Kædmon, den blinde fårehyrde, der blev en stor skjald, er måske en Ossian-præfiguration? 
Med Bradley som leder indledte Center for Grundtvigstudier i 1998 en nøjere udforskning af betydningen af Grundtvigs møde med "det angelsaksiske". Herom rapporterer Bradley i GrSt 1999 - om opdagelsen af Englands "skrinlagte fortid". Hvor især Thaning har lagt vægt på rækkevidden af mødet med det moderne England, er det mødet med det oldengelske, som Bradley lægger vægt på. Grundtvigs ærinde som oversætter var ikke kun videnskabeligt, men indgik i en videre bestræbelse på "at vække til forståelse af folkeånden og folkeligheden”. På den baggrund er der god grund til et nøjere studium både i bredden og også punktuelt - fremhæves det programmatisk.

Bradleys optagethed af Grundtvig og "det angelsaksiske" har resulteret i flere senere bidrag. ${ }^{35}$ I GrSt 2000 diskuterer han Grundtvigs jo unægtelig ret frie Beowulf-oversættelse, der via-à-vis Thorkelins latinske version netop skulle fremtræde " $\mathrm{i}$ sin velbehagelige poetiske Skikkelse". Hvad dette indebar, kunne man med tanke på hans arkaisering i oversatte norrøne tekster nære en vis frygt for (Rasmus Rask talte om "Usædvanligheder og Særheder"). Grundtvig ved meget vel, at en ordret oversættelse ihjelslår ånden, som han netop vil have i tale: "Det er hvad jeg kalder at oversætte Digte" - hvilket er bidragets titel. Hans løsning lader sig sammenligne med Seamus Heaneys i den Beowulf, han udgav i 1999.

Allerede da Grundtvig i 1828 forhørte sig hos kongen om penge til de påtænkte Englandsrejser, havde han med J. P. Bangs ord et veludviklet blik for "Angelsaksernes kirkehistoriske Betydning". Det Kongelige Bibliotek var rigt forsynet med angelsaksiske kildeskrifter, og Grundtvig studerede dem flittigt (ikke mindst George Hickes' tobindsantologi Thesaurus). I GrSt 2002 går Bradley tæt på disse studier med fokusering til sidst på "De Levendes Land", hvis titel han argumenterer for er fundet i Hickes-antologien, der netop oftere har udtrykket $\mathrm{i}$ en betydning svarende til digtets ("Mit Land, siger Livet, er Himmel og Jord, / hvor Kiærlighed boer!"), mens for eksempel Bibelen bruger det alene om livet hér. Fønix-motivets udmøntning peger ligeledes mod angelsaksisk litteratur.

Og i "Before Irenaeus. The Making of Grundtvig the Medievalist" (GrSt 2004) indkredser han udbyttet af den hidtidige forskning vedrørende Grundtvigs kendskab til angelsaksisk traderede oldkirkelige kristendomstolkninger. Disse studier bidrog også til det billedsprog, som jo var og blev Grundtvigs særkende. Videre peges på historikeren Beda og skjalden Kædmon - samt Exeter-bogen med "The Seafarer" som baggrund for Grundtvigs "Sidste Digt" (jf. ndf.). Fælles for disse skrifter er, at de sammenkæder historieskrivning med forsynstro og

- som er imponerende kundskabstunge, men som læst i sammenhæng unægtelig præges af en vis redundans. 
med kirkeårets liturgiske kredsløb. Bradley argumenterer for, at enhver udforskning af Grundtvigs møde med førreformatorisk overlevering må inddrage "hans oldengelske møde med arven fra den tidlige middelalder $0 \mathrm{~g}$ give den en betydningsfuld plads". ${ }^{36}$

I GrSt 2006 behandler Bradley emnet "Grundtvig, Bede and the Testimony of Antiquity". I Bedas store kirkehistoriske værk (o. 730) fandt Grundtvig utvivlsomt bekræftelse for den af ham selv udviklede historiefilosofi. Værket gennemtrænges af vilje til at forme en national identitet, som allerede titlens "gentis Anglorum" lader forstå. Det fælles for den politisk fragmenterede befolkning lå i det sproglige og kulturelle, men mest overgribende dog i det forhold, at den udgjorde én kristen menighed. Bedas værk fremviser et nordisk folks nationale identitet "in terms of a national congregation, in orthodox unity with the greater family of the historical and universal Church", og tilmed tilkender den på flere vigtige punkter kvinder en positiv rolle. Bedas historieforestilling er for så vidt en kirkens historiske udfoldelse i et udvalgt folk. Uden at gå ind i en diskussion om Ole Vinds opfattelse af Grundtvigs historiefilosofi finder han dennes udredning af den angelsaksiske indvirkning præcis og korrekt. Dette fører ham over i en afbalancering mellem Bedas latinske historiefremstilling og den folkesproglige digtning, især Beowulf - hvor vidnesbyrdene om Grundtvigs interesse jo er mere entydige. Bradley peger på "an ideological affinity" mellem Beowulf's ophavsmand og Beda og pointerer, at frem for at se på enkeltforhold må man se på hele den angelsaksiske historiefilosofi, hele den universalhistoriske kontekst, hvori Beda indsætter historien om etableringen og den tidlige udvikling af den engelske menighed. Grundtvigs tilegnelse af den sag kan ikke ses som en pludselig opdagelse i 1832, men "er fremgået af den årelange interesse for angelsaksisk digtning forbundet med drømmen om at skabe en universalhistorisk Vidskab", med Ole Vinds formulering.

I GrSt 2008 drejer det sig specielt om Grundtvigs optagethed af Exeter-håndskriftets gåder og hans overvejelser i den forbindelse vedrørende for eksempel intellektuelle strategier og folkelige motiver. ${ }^{37}$

36 GrSt 2004 indeholder også en Bradley-artikel om Exeter-bogens betydning, hvad angår billedsproget specielt i digtet "Rune-Bladet". - Ved en tidligere lejlighed (GrSt 1993) har Bradley påpeget, at der i Palmesøndagsprædikenen fra 1867 ikke blot er "rambling of a mind", men også "some rational coherence"; især er det rimeligt at antage, at den rummer allusion til Exeter-bogens digt "The Descent into Hell".

37 Grundtvig planlagde som bekendt en udgave af de vigtigste angelsaksiske håndskrifter, inkl. Exeter-håndskriftet. Opgaven overgik til Benjamin Thorpe, hvis udgave (1842) kun giver få gådeløsninger, så Grundtvig skylder ham 
Når de fromme munke fik biblioteksadgang til sådanne tilsyneladende trivielle eller frivole sager, bør det ses i sammenhæng med en middelalderlig fortolkningstradition opsummeret af Thomas Aquinas og gående ud på, at åndelige sandheder kan befordres ved sammenligning med materielle, sanselige, kropslige ting. I en vis forstand er vi jo alle, stedt over for livets store gåder, eksegeter for Vorherre. Exetermanuskriptet stillede Grundtvig over for fænomenet "gåder i gåder" kenninger at tyde, runer at råde. Det lykkedes ikke altid, for eksempel ikke $\mathrm{i}$ en gåde, hvis løsning fremkommer, når man tilbagesætter indføjede runenavne til runetegn og sammenføjer disse til ord; løsningen er "hane og høne". Grundtvig havde fært af det uartige og var landet på "lås og nøgle".

Merete Bøye har i GrSt 1998 grebet fat i ét aspekt i den angelsaksiske poesi, modsætningen mellem hal og hav, som man møder den $\mathrm{i}$ Beowulf. Modsætningen altså mellem liv(sfællesskab) og død, som Andreas Haarder opridser den i sin disputats. Denne eksistentielle dualisme, beskrevet af Henning Høirup i Fra døden til livet, dukker ofte op hos Grundtvig som eskatologisk modsætningsforhold, jf. formuleringen "fra Dødninge-Hjem til de Levendes Land". Fortrøstning var at finde for eksempel i beretningen om, hvordan Jesus stillede stormen på søen. På verdens vidtløftige hav sejler man sikrest med kirkeskib. Bøye argumenterer for, at motivet er inspirationskilde også i "Gammel nok jeg nu er blevet".

Grundtvig havde som bekendt en forestilling om, at hans universalhistoriske anskuelse burde kunne afhændes på det engelske marked, men måtte konstatere, at menneskesynet dér var materialistisk og utilitaristisk. Båndene bagud til den verden, som spejlede sig i de angelsaksiske manuskripter, var tyndslidte. Men netop fordi manuskripterne bevidnede englændernes plads i universalhistorien, opgav Grundtvig ikke ævred. Rejsen i 1843 skulle - som Helge Grell pointerer i artiklen "'Langt mere eventyrligt end historisk': Om Grundtvigs forhold til England" (GrSt 1993) - tjene til "opvækkelse af historisk oplysning og folkelig dannelse", samt bringe ham i debat med lederne af de såkaldte oxfordere, blandt andet J. H. Newman, som han opnåede en "meget fattig" samtale med. Heller ikke andre kulturpersonligheder, som han mødte, sagde ham ret meget.

\section{Andre bidrag}

Sigurd Aarnes beskæftiger sig i GrSt 1967 med "Den unge Grundtvig som litteraturteoretiker". Grundtvig lagde ud med den Holberg-raptus i

ikke meget i den henseende. Bradley offentliggjorde i 1998 en analyse af Grundtvigs transskriptioner i Grundtvig-arkivet, fasc. 316:1-8. 
1804 , som også K. E. Bugge har skrevet om, ${ }^{38}$ men erindrede året efter Steffens' bestemmelse af poesien som bærer af "det Eviges Præg" over for prosaens blot endelige tendens. Men vel at mærke: det poetiske beror i mennesket, ikke som en kunstnerisk udtrykstrang, men som en "Higen ud over det Synlige". Constance Leths jordiske skønhed sublimeres til anelse om det evige. At resultatet blev netop en "asarus", kan man vel takke P. N. Skougaard for. Men 1810-krisen forvandlede jo Grundtvig fra nordisk til kristen skjald, en tid lang på jagt efter en formel til legitimation af også verdslig kunstudfoldelse, som han såmænd fandt i Paulus' nævnelse i Areopagos-talen af de græske digteres "naturlige gudsåpenbaring". Poesien knyttes altså til teologiens forestilling om gudbilledlighed; den bliver en art gudsåbenbaring, og digteren/seeren opfattes næsten på linje med profeterne (som i Herders skrift om hebraisk poesi).

Morten Bredsdorffs "Grundtvig og Shakespeare" (GrSt 1969) tegner linjen fra den Steffens-inspirerede læsning af Shakespeare i Schlegels tyske oversættelse til erhvervelsen under Englands-opholdene af "en på den tid for en dansker ret enestående fortrolighed med Shakespeares skuespil", endda med fin sans for munterheden. Eftersom englænderen var ufordærvet af latinen, kunne han i Nordens Mythologi gælde som garant for Grundtvigs "kulturpolitiske drøm" om en nordisk-angelsaksisk renæssance. For nu slet ikke at nævne hans paternitet til tragedien om Hamlet, prins af Danmark.

Bredsdorff har også studeret "Sjællandske træk i Grundtvigs sprog og digtning" (GrSt 1959) - og fremfundet ganske mange udsagn om veneration for det sydsjællandske udspring. Hvad han annammede af barnepigen Malenes ordforråd og vendinger, er løbet ind i forfatterskabet, ikke mindst i Saxo-oversættelsens borgestuedansk. Der er også sjællandske landskabsbilleder i hans digtning, eller vel snarere særdanske: "Skin over Vang som en Morgen med Sang, / Morgen i Maj, naar det grønnes". 39

I GrSt 1980 diskuterer Bodil Schmidt Grundtvigs "betragtning af modersmålet i teori og praksis" med afsæt i Danne-Virke-afhandlingen "Om Ordsprog". Omsorgen for de af oplysningslitteraterne miskendte ordsprog forbinder sig med samtidens gængse synspunkter vedrørende folkelighed, modersmål og fædrelandsfølelse. Med ordsprogene traderedes en åndelighed, der måske beroede på selve sprogtilblivelsen, altså på at sproget er åbenbaret (jf. Johannes-evangeliets indlednings-

\footnotetext{
38 Nemlig i Gustav Albeck-festskriftet Guldalderstudier (1966).

39 Hertil tør jeg føje en personlig erindring. I en samtale med professor Carl Fehrman (Lund) udbrød han, egentlig ganske umotiveret, at ingen svensk digter kunne have skrevet vers som disse: "Som Hønen klukker mindelig / saa' Kirke-Klokken ringer".
} 
ord). Oldsproget vidnede om "en billedlig Beskuelse af Alt", og jo mere åndelighed der var i sproget, jo mere poesi var der i folket - men aldring truer folkekarakteren, skriftligheden underminerer det levende ord, og bogstaven ihjelslår ånden. Ordsprogenes revitalisering tjener omvendt poesiens sag. I øvrigt var det Grundtvigs tanke, at de sprogvidenskabelige begrebsudviklinger bør kunne fattes med "den almindelige Menneske-Forstand", og at den afgørende prøve beroede på, "hvad Ordet betyder i Folke-Munde" - et pragmatisk synspunkt med perspektiver op i vor tid, som Bodil Schmidt sluttelig pointerer. ${ }^{40}$

Henrik Wigh-Poulsens motivstudie "Barnet i haven" (GrSt 1996) tager udgangspunkt i de to Saga-digte "Til Sibbern" og "Udby Have" for at indsætte dem både $i$ en personlig og en litterær sammenhæng, den europæiske pastoraletradition. Hjemfærden og hjemkomsten er skildret fra rolighedens tilvundne position, som en "romantisk dannelsesrejse", dog uden henvisning til dannelsesromanens (og mange folkeeventyrs) velkendte trefasede struktur. Pastoralen opfattes ganske bredt, som en længsel mod tabt uskyld, oprindelighed, overskuelighed, osv., men i romantikken forskyder den sig i individuel retning, og vel tillige fra arkadiske hyrdescener til paradisiske barndomserindringer. Uskyldstabet konnoterer under alle omstændigheder syndefald og opbrud. Udby-havens gange bliver trange, og Egeløkke-havens blomster minder ligefrem om dårskab og død. Men uskylden kan genvindes ved selvbesindelse og med hjælp fra Gud. Den hjemkomne digter skriver sig for så vidt ud af pastoralen, dog altså uden at sætte det i dens tradition overstyr, der er rodfæstet i bibelsk billedbrug - for i alvor og sandhed at blive sin flok en god pastor. Med "Paaske-Liljen" repeteres hjemkomsten: "Barnedage! Følger nu / med mig ud i Faders Have!" og videre ud i det åbne land for at "synge med i det store kor". ${ }^{41}$

I 1849, midt under Treårskrigen, udgav P. O. Boisen Nye og gamle Viser af og for det danske Folk, som der sættes fokus på i Hans Kuhns artikel "Grundtvig and the War that Changed Danish Identity" (GrSt 2000). Sangbogen blev frem til 1875 trykt i en række forøgede udgaver, vistnok i hen ved 70.000 eks. Outsideren Grundtvig red på den nationalistiske bølge ind i varmen og hentede som hovedleverandør sine fleste bidrag fra den bunke på ca. 150 sange, som han skrev til sit eget ugeblad Danskeren. Artiklen skitserer hovedtrækkene af den danskhedsmyte, som han havde formuleret langt tidligere, men nu bragte på slagkraftige vers til kendte melodier. Sort ser det ud, men Gud skal nok komme sit udvalgte folk til undsætning - with a little

40 Jf. den Grundtvig-tale fra 1839 om danskhed og modersmål, som Flemming Lundgreen-Nielsen har offentliggjort i GrSt 1992.

41 Jf. Wigh-Poulsens Hjemkomsten og det åbne land (2001), der læser Jakob Knudsens forfatterskab ud fra den grundtvigske realisme. 
help from his friends: Thor med hammeren Mjølner og Uffe med sværdet Skræp og skjoldmøerne og rigsvåbnets løver.

\section{Grundtvigs teologi ${ }^{42}$}

Jakob Rod skitserer i GrSt 1970 "den lige linje" i Grundtvigs religiøse udvikling. Linjen, der går mod selvrealisation i den analytiske psykologis kvalificerede mening af ordet, begynder, hvor barnetroen får overtaget efter det bibelfundamentalistiske eventyr, eller længere tilbage, om man lader eventyret gælde som en udskejelse uden rod i Grundtvigs "dybere sjæleliv", hvoraf digtning udspringer. Roskilde-rimene er for eksempel en angstfremkaldt tour de force, mens "NyaarsMorgen" nærmest er en invitation til løvsalsfest. Men jævn er vejen jo ikke, trosbekendelsen kan begribes som kult, men også ende som lære. Fuldbyrdelsen indtræder i det også for Kaj Thaning så afgørende år 1832.

\section{Thaning-linjen}

Thaning beskæftigede sig i GrSt 1953 med "Grundtvigs møde med Irenæus", et forarbejde til disputatsen Menneske først - (1963), og især med fokus på prædikenerne i 1823-24. Lyon-biskoppen fik gennem sit skrift mod kætterne - hvis femte bog Grundtvig jo i 1827 oversatte afgørende indflydelse på den forskydning af synet på den lutherske kristendom, som blev udkommet. Adventsprædikenen "Dagningen" og digtet "De Levendes Land" skaffede ham den attråede teologiske og poetiske klarhed - men undermineringen af bodskristendommen foregik, som det fremgår af prædikenerne, langsomt og diskontinuerligt. Det centrale problem for Grundtvig var jo forholdet mellem Gud og menneske. Irenæus - placeret i den mundtlige tradition fra Polykarp og Johannes - betonede Guds kærlighed og menneskets skabthed, det forhold, at det i sig havde brudstykker af "det ved Synden forstyrrede Guds Billede". I "Dagningen" ytrer han forundring og taknemmelighed over lyset, der "nu, naar vi stirre vist paa Skriften, udvælder, oplyser, omskinner, giennemstraaler, og fordi det er Livets Lys, giennemgløder os, forvandler vort Haab, som er Guds Rige inden i os, fra Dunkelhed til Klarhed over Klarhed”. På denne baggrund begynder digtet at arbejde sig frem, med Kingo som basis og Irenæus som fødselshjælper. Thaning daterer det til den første uge i februar 1824 og parafraserer det med fortsat henvisning til prædikenerne. Slutningen, "Mit

42 Jf. Kim Arne Pedersen, "Den teologiske Grundtvig-forskning siden Anden Verdenskrig”, i Hanne Sanders \& Ole Vind (red.), Grundtvig nyckeln till det danska, Stockholm 2003, 150-79. 
Land, siger Livet, er Himmel og Jord, hvor Kiærlighed boer!", er Irenæus - dog tilsat et stænk af ungdommens romantik, som først blev bortredigeret i 1853 . $^{43}$

Menneske først - fremlægger en overvældende dokumentation (hen ved 800 sider) af en allerede i 1941 formuleret tese om 1832 som det afgørende vendepunkt $\mathrm{i}$ forfatterskabet ${ }^{44}$ - og samtidig en indkredsning af det endnu levende i dette. Harry Aronson beundrer den enestående indsats, men kritiserer metoden (GrSt 1964). Thaning ikke blot affærdiger den meste forskning i tiden før 1832, han skildrer den også "baglæns", ud fra 1832-positionen, ikke prospektivt, og han ser bort fra materiale, der er genstridigt i forhold til tesen. Subjektiviteten er til at få øje på, det Grundtvig-ansigt, vi ser, er "påfallande likt" Thanings eget. Tesen er da også udsprunget af tredivernes tidehvervske opgør og lanceret forud for to årtiers strid med det enorme materiale, der skulle levere dokumentation (men ikke underminering). Arbejdets ideologiske karakter illustreres af en løsagtig anvendelse af sækulariseringsbegrebet. Sækulariseringen lanceres som "en god frukt" af 1832omvendelsen, en faktor, der ad bagvejen "bestämmer tolkningen av Grundtvigs teologi och idévärld överhuvudtaget". Thaning medgiver, at verifikation af hans tese fordrer kongenialitet, "ganske bestemte subjektive, personlige forudsætninger" af fortolkeren \& læseren. En sådan egenskab finder han ikke hos Aronson, hvis disputats han i slutkapitlet leverer en så urimelig læsning af, at det giver Aronson anledning til en ganske harsk antikritik - som Thaning i GrSt 1965 brugte megen energi på at hakke til spåner: Aronson har ikke "fattet min tese", og han "forstår heller ikke min metode og mit mål". Det skete i et langt "Svar til tre kritikere" (Aronsen, samt William Michelsen og Helge Toldberg), som i GrSt 1966 blev suppleret med et svar - "Holdt tesen?" - på A. Pontoppidan Thyssens opposition. I alt 65 sider, til dels relateret til kritik fremkommet andetsteds (i Dansk Udsyn, Danske Studier og Kirkehistoriske Samlinger). ${ }^{45}$ Her blot et par ord om "Holdt

43 Jf. Anders-Christian Jacobsen, "Afgrænsningen mellem sand og falsk skrifttolkning hos Irenæus og Grundtvig" (GrSt 1997), der argumenterer for, at Irenæus-læsning lå til grund for opdagelsen af "trosbekendelsens funktion som sammenfatning af de kristne grundlærdomme og som kriterium for skrifttolkningen". Fortalen til Kirkens Gienmeele er som bekendt dateret: "Irenæi Dag 1825". - Andre frugter af Jacobsens Irenæus-interesse er kommentaren til Grundtvigs oversættelse af et kapitel af Mod Koetterne ( $\mathrm{GrSt}$ 1998), samt introduktionen til Ulla Kiels nyoversættelse af værkets femte bog (1999). Kiel har i GrSt 1997 transskriberet og kommenteret Grundtvigs Irenæus-optegnelser.

44 Jf. artiklen "Et tredje Grundtvig-Standpunkt", Tidehverv, 1941.

45 Michelsens "Om Grundtvigs historiesyn" (GrSt 1965), der omfattes af Thanings "Svar", viderefører en debat indledt andetsteds. - Netop på dette 
tesen?" Uenigheden med Pontoppidan Thyssen er både metodisk, eksegetisk og teologisk, pointerer Thaning, der i øvrigt benytter lejligheden til at levere dokumentation for Grundtvigs "kamp for klarhed" inden 1832-afklaringen (250 sider blev angiveligt "tilbudt mine bedømmere", men kun 50 sider kom med i bogen!). Et væsentligt punkt vedrører sækulariseringen, der for Thaning er en uundgåelig konsekvens af Grundtvigs erkendelse af behovet for at holde tingene adskilt; menneskelivet og hvad dets er (inklusive ånd) kan efter 1832 løftes ud af "kirkens favntag". Programmet for Grundtvigs virke måtte således blive: "Historiker først - og prædikant så"; men under frihedens sol foreligger jo dog den levende vekselvirknings mulighed. Når Pontoppidan Thyssen ikke begriber dette, er det for Thaning at se, fordi han vil udfinde inkonsekvens hos Grundtvig frem for at erfare, hvad denne egentlig mener - og Grundtvig vidste nok, hvad han mente. Pontoppidan Thyssen vil sætte Grundtvig på plads i kirkehistorien, Thaning vil finde frem til "det udfordrende, mandens særlige ærinde". For ham er der ikke afstand mellem den "levende" Grundtvig og den "historiske".

Ejvind Larsens artikel "En naturfilosof efter Grundtvigs hjerte" (GrSt 1973) forholder sig Pontoppidan Thyssen'sk til Thanings disputats. I 1832 ville Grundtvig gerne holde skole med de åndfulde naturalister - men i 1836 beder han dem "fare til Paven i Rom". At klogskab ikke kunne lede til "Siælens Hiem", vidste han meget vel fra dimisprædikenen. Alligevel stred han selvrådigt med kvalifikationsproblemet frem til Nyaars-Morgen-erkendelsen af, at "Lys uden Varme / er Helvedes Kval" - og videre frem til den af Thaning oversete henvisning i mytologi-indledningen 1832 til Shakespeares As You Like It, hvor hyrden Corin har den folkelige filosofi i sig, "at en Hovedaarsag til, at det er Nat, er Mangel paa Sol" (hvor den schellingske naturfilosofi jo antager, "at Mørket er det, hvoraf Lyset har udviklet sig"). Det forekommer således Larsen en gåde, hvorfor Thaning lader Grundtvig invitere de åndfulde naturalister på folkelig højskole, og netop i $1832 .{ }^{46}$

Som Kaj Thaning i Asperup, således Bent Christensen i Døllefjelde - engageret præstegårdsforskning på højt niveau. Christensen lægger sig i kollegaens kølvand med hensyn til betydningen af 1832 som det store vendepunkt, dog tydeligere i licentiatafhandlingen Fra

sted kan henvises til min bibliografi Grundtvig-litteratur 1963-1985 (1986), hvor Thanings disputats og hvad den trak med sig er fortegnet u. nr. 105 .

46 Jf. Kaj Thanings anmeldelse i GrSt 1974 af Larsens Grundtvig - og noget om Marx (1974), hvori bidraget indgår. Thaning medgiver, at han har misforstået Shakespeare-referencen, men finder, at også Larsen har misforstået den. 
drøm til program (1987), der udforsker "menneskelivets" plads i Grundtvigs kristendomsforståelse i de afgørende år mellem 1824 og $1832,{ }^{47}$ end i disputatsen, Omkring Grundtvigs Vidskab (1998), der studerer Grundtvigs forhold til "den erkendelsesmæssige side af det kristeligt nødvendige livsengagement", og herunder ganske vist stadig finder et højdepunkt i indledningen til Nordens Mythologi, men dog også finder, at den markerer en omstigning, hvad angår den såkaldte "Vidskab", starten på en nedtoning altså. Vidskab er en universalhistorisk kategori, meget mere omfattende og eksistentielt præget end "almindelig" videnskabelig erkendelse.

Denne nedstigning til en positivitet af lavere orden ser Theodor Jørgensen i sin opposition (GrSt 1999) på en anden måde, som "en udvidelse af forståelseshorisonten til den kristne kirkes katolicitet", en dybere sans for det lokale og folkelige, altså en tøjling af den høje idealitetsstræben, som lurede på Grundtvig trods al hans romantikkritik. Jørgensen påpeger, at en stor del af Grundtvigs virke foregår i et spændingsfelt mellem det universelle og det partikulære. I medfør af udvælgelsestanken tillægges det lokale en universel værdi, den danske sag bliver Guds sag, osv.

Også A. Pontoppidan Thyssen forholdt sig i sin opposition (GrSt 1999) kritisk, men snarere til selve udpegningen af 1832. Med henvisning til P. G. Lindhardts ironiseren over den ældre Grundtvig-forsknings "årstals-grundtvigianisme", inklusive Thanings fokusering på 1832, der som nævnt blev lanceret som "tese" allerede i 1941, lægger han vægt på gradvis udvikling - og er måske netop derfor mest optaget af Christensens store kapitel om Danne-Virke, specielt de bidrag, som Christensen gerne vil læse som sammenhængende, og som for ham udgør et første højdepunkt.

Et Christensen-indlæg i Thaning-debatten havde overskriften “Menneske først, kristen så - og hvad så?" Disputatsens svar er, at det afgørende er betydningen, engagementet, livsfylden. Derfor kan Chris-

47 Jf. Bent Christensens licentiatforelæsning "Var Grundtvigs nyerkendelse i 1832 en tragisk hændelse?" (GrSt 1989-90, efter fire års lagring). Christensen finder ikke Thanings 1832-Grundtvig "bedre" end ham, der i 1824 skrev "Dagningen". Det tragiske består kirkepolitisk deri, at det "forlig", som Grundtvig i 1832 følte sig nødsaget til at indgå, er blevet ophøjet til den i dag "eneste rigtige måde at føre kirke på". Christensen rejser imidlertid et andet problem: var gennembruddet "en erobring af nyt land eller et strategisk tilbagetog?" Aage Henriksen har ytret, at med "Nyaars-Morgen" påbegyndtes "den lange nedstigning [...] Grundtvigs forvandling til grundtvigianisme". Christensen bebrejder ham ikke nedstigningen, men betvivler dog, at programmet nu også var "det helt rigtige". Idealet synes at være drømmen fra 1824 kombineret med det program fra 1861, som skitseres i Den christelige Børnelcerdom. 
tensen ikke give Pontoppidan Thyssen ret i, at der i afhandlingen er for lidt metodisk stringens og for megen lovprisning, jf. hans indledning ved disputatsforsvaret og replikker til de officielle opponenter i $\mathrm{GrSt}$ 2001 .

Thaning-linjen i dansk teologi og Grundtvig-forskning blev i GrSt 2002 analyseret af Mikkel Crone Nielsen, særligt med henblik på den omdiskuterede sækulariseringsteologi, der via-à-vis mellemkrigstidens grundtvigianske lukkethed netop indebærer en afgørende forskydning i forholdet mellem menneskeliv og kristendom, og dermed et under Englandsrejserne befæstet nyt kristendomssyn, der sætter skel og sætter kristendommen i tjeneste hos det menneskelige. Hermed var kursen sat for en Grundtvig-beskæftigelse, der søgte bagom grundtvigianismen og et kvart århundrede senere blev en del af programmet for Grundtvig-Selskabet. Vejen over den levende Gud gik til det levende menneske i dets timelige livs egenværdi. Ud over sækulariseringsteologien drøfter Crone Nielsens artikel "metodespørgsmålet" hos Thaning, hvad han jo knap nok selv gør (jf. Bent Christensen, ovf.). Han peger på Bultmann-påvirkning og også på den arv efter Vilhelm Grønbech, der har at gøre med hans opgør med det europæiske menneskes fiksering af, hvad han kalder pilgrimsmyten, af Thaning udstrakt til at være et menneskeligt grundvilkår. Netop dette gør ifølge Crone Nielsen samtalen mellem Grundtvig og nutidsmennesket mulig og interessant. $^{48}$

Om tilblivelsen af Grundtvigs mageløse opdagelse handler et bidrag af Kaj Thaning i GrSt 1981. Opdagelsen, dateret til den sidste uge i juli 1825, sker i to tempi; først begriber Grundtvig, at kirken var før skriften, dernæst at trosbekendelsen så at sige var før kirken. Læsning i Neanders Antignostikus umiddelbart forinden kan have skærpet hans blik for sagen, som ugens mange udkast antyder. Afklaringen sætter sit præg på anden del af afhandlingen "Om den sande Christendom", men endnu ikke på første del. I forhold til rationalisterne bliver der råd til kådhed. Selve prædikenen af 31. juli, inklusive den før ukendte slutning, aftrykkes i GrSt 1982.

Opdagelsen bliver ifølge Thaning først i 1832 til en selvklarhed. Jens Rasmussens skildring i GrSt 1998 af konflikten 1825-32 er for så vidt et indlæg i diskussionen omkring Thanings disputats. Da opdagelsen blev udfoldet i Kirkens Gienmale, og skriftteologen H. N. Clausens "Kulsvier-Tro" udfordret, kom det til den injuriesag, der kostede

48 Til artiklen knytter sig en bibliografi over Kaj Thanings forfatterskab (GrSt 2002, 142-52). 
Grundtvig den dyrebare forkyndelsesfrihed. ${ }^{49}$ Under hans påfølgende forsøg på at indfri genmælets løfte om historisk bevisførelse for trosbekendelsens primat nåede han, uden at føre beviset, til "en stadig klarere forståelse af sin kirkelige anskuelse". Mens ritualdebatten rasede, formulerede han sine tilvundne synspunkter i Den danske Stats-Kirke upartisk betragtet (1834), der skitserer tankerne om præstefrihed og sognebåndsløsning. ${ }^{50}$

Den mageløse opdagelse er også behandlet af Kaj Baagø ( $\mathrm{GrSt}$ 1957), med fokus på, hvilke "samtidige kirkepolitiske og teologiske tanker" der kan have bidraget til den. Et hyrdebrev søgte i 1817 at imødekomme flere yngre teologers utilfredshed med den såkaldte symbolforpligtelse, men afværgede ikke den kirkekamp, som begyndte sidst i 1824, og uden at Grundtvig havde samme andel deri som for eksempel A. G. Rudelbach, sammen med hvem han redigerede Theologisk Maanedsskrift. I samhu med Steffens' 1823-kritik af teologernes "exegetiske pavedømme" fremhævede de, at det tilkom troende at drive "ret skriftfortolkning". Et nyt syn på kirken, "som den levende kæde af troende og bekendende", spirede frem - og endelig blev trosbekendelsen erkendt som kristendommens sande udtryk, hvad man havde glemt, men hvad et par tyske teologer havde opfrisket, "før jeg stræbde at giøre det gjældende i Danmark". Mere mageløs var opdagelsen trods alt ikke!

\section{Forholdet til Luther}

Spørgsmålet om Grundtvigs forhold til Luther er ikke enkelt. I GrSt 1948 gør Regin Prenter op med den gængse udlægning af Grundtvigs syn på forkyndelsen. Grundtvig taler, tilsyneladende Luther-fjernt, om "forkyndelsen som livstegn". Prenter sætter dette i forbindelse med "tanken om tro, håb og kærlighed som udtryk for det voksende Kristusliv i menigheden - og tankerne om kirke og skole". For Grundtvig er forkyndelsen en videreførelse af "Pinsedagens Underværk", og i dette finder Prenter ingen væsentlig afstand til Luthers forståelse, at Gud er "levende nær" i sit ord. Længere er der til, hvad arkitekten indskrev på Grundtvig-kirkens prædikestol: "Læs Ordet, som staar skrevet, / men vidn, hvad du har levet!" Denne "mer end forbløffende Sentens", som en redaktionel note anfører, dækker måske, hvad der "i stor udstrækning i vore dage er rådende blandt Grundtvigs disciple",

49 Jf. Grete Bøje, "Injuriesagen mod Grundtvig 1825-1826" (GrSt 1984). Sagens vigtighed fremhæves i årgangens redaktionelle forord: den "ændrede totalt ikke blot Grundtvig, men også den kristne kirkes liv i Danmark".

50 Jf. Poul Dam, "Noget om myterne omkring den Clausen'ske injuriesag og Grundtvigs censurperiodes afslutning" (GrSt 1999). 
men den dækker til gengæld ikke Grundtvigs opfattelse, hvad artiklen argumenterer for især ud fra Den christelige Børnelaerdom. For Prenter vil det "stemme godt" at synge grundtvigske helligåndssalmer til lutherske prædikener.

I et bidrag til GrSt 1998 anfører Leif Grane, at det naturligvis væsentlige forhold til den tyske reformator kommer tydeligst frem i de historiske og - med Granes citationstegn - "teologiske" skrifter. Med barndomsforankring i luthersk ortodoksi måtte forholdet starte med et opgør, efter de tidlige moralistiske prædikener. Med krisen i 1810-11 rykkede den skriftbaserede kristendom ind og den ortodokse moralisme definitivt ud. Den Luther, som han fremkaldte i Verdenskrønikens reformationsafsnit, havde, modsat lutherdommen og også modsat de andre reformationsskikkelser, "poetisk sans og profetisk forkyndelse". Denne forståelse blev fastholdt, om end accentueringen skiftede, især med Kirkens Gienmoele og beslægtede skrifter, hvor Grundtvig får hold på sit kirkesyn og dermed på sin uenighed med Luther - i enighed med ham om "Helligånden som eneste statholder og Herrens indstiftelser som eneste salighedsmidler", understøttet af levende forkyndelse ledsaget af salmesang osv., alt på modersmålet. Grundtvig må i dette stykke bære over med mangt og meget, for eksempel at Luther med "forkerte principper" havde lagt grunden til afsporingen, skriftklogskaben osv. Den "ufærdige" reformation må nu tage et nyt skridt mod den fuldbyrdelse, der ganske vist først indtræffer ved tidernes ende. Troen er konstant, teologien tidsbestemt, indså Grundtvig, derfor hans komplicerede, basalt "positive" omgang med reformatoren - "den ypperligste Fader i Kristus siden Apostlenes Dage", som han kaldte ham i en kirkelig lejlighedstale. Det citat afslutter artiklen.

Theodor Jørgensen henholder sig i sin diskussion af Grundtvigs forhold til den lutherske tradition (også i GrSt 1998) mest til 1830-artiklen "Skal den lutherske Reformation virkelig fortsættes?" Hans indkredsning af traditionen danner baggrund for en fokusering på kirke/skole-forholdet (tro/teologi-forholdet, kirkeord/skriftord-forholdet, osv.). Skriftklogskaben må underlægge sig troen, funderet på trosbekendelse og dåbspagt. Kætteri bliver i forlængelse heraf tilsidesættelse af trosbekendelsen, ikke af skriftdiktater og dermed af "exegeternes pavedømme". Således bliver der sikret kirken stor rummelighed, dog for Grundtvig selv ikke så stor, at udelukkelse fra nadverfællesskabet som kirketugtsredskab bliver utænkelig.

Anja Stokholms analyse i GrSt 2003 af forholdet mellem skabelse og syndefald hos de to forkyndere udviser hårfin balance $i$ afvejningen. Med udgangspunkt i Prenters argumentation for, at "Grundtvigs tale om den bevarede gudbilledlighed ikke fører til en ophævelse af Luthers tanke om den trælbundne vilje", opsøger artiklen mulige 
sprækker. Mennesket er jo for Grundtvig ikke nogen abekat, det er skabt "som et Guddommeligt Experiment, der viser, hvordan Aand og Støv kan giennemtrænge hinanden”. Således kommer gudbilledligheden på bane: ved syndefaldet forblev en rest af det oprindeligt guddommelige deponeret i mennesket, og med ord i mund og hjerte på rette sted er da genløsningsmuligheden bevaret. Denne insisteren på, at "Guds skabelsesnåde" beror i menneskets indre, forholder sig afgørende kritisk til "ikke kun den lutherske ortodoksi", den rammer "selve nerven i Luthers tænkning". Eller andetsteds sagt: Grundtvig kan i modsætning til Luther "ved at definere menneskets lighed med Gud som ordets samt troens, håbets og kærlighedens mulighed, fastholde tanken om en rest af lighed med skaberen". Det går således ikke an at sætte lighedstegn mellem Luthers "lov og evangelium" og Grundtvigs "menneske først, kristen så". Mangt og meget, som i luthersk tradition har givet anledning til prædikatet "skyldigt", dømmes menneskeligere hos Grundtvig.

Uden inddragelse af Stokholms artikel behandler Ove Korsgaard i GrSt 2004 emnet fra andet hold, men også med den konklusion, at overensstemmelsen ikke er så stor som almindeligt formodet. ${ }^{51}$ Korsgaard går begrebshistorisk til værks. Han ser på forholdet mellem samfundsmæssige forskydninger og verbale betydningsændringer. For eksempel betyder 'nation' og 'folk' ikke det samme hos de to forfattere, hvad man ved sammenligning naturligvis må tage hensyn til; først på Grundtvigs tid (og ansporet af ham) løber betydningerne sammen, efter hver for sig at have oplevet flere forskydninger. På baggrund af en skildring af Luthers toregimentelære og den deraf afledte magtfordeling mellem kirke og verdslig myndighed opregnes tre punkter, hvor overgangen fra lutherdom til folkedom viser sig Luther-kritisk: den skriftbaserede ortodoksi viger for det levende ord, den lutherske syndsfundamentalisme erstattes af gudbilledligheden, og den lutherske statsfundamentalisme undermineres. Korsgaard drøfter i særdeleshed de konsekvenser, dette får for kristendomsundervisningen, som Grundtvig jo anbefaler udtaget af de offentlige skoler. Samfundsborgeruddannelsen skulle "være eens baade for Christne og Jøder og Hedninger, og bør staae aldeles uden for Troes-Sagen". Artiklens titel "Fra tugtemester til skolemester" refererer til Grundtvigs problematisering i 1852 af "det centrale lutherske forhold mellem lov og evangelium". I det hele taget er det Grundtvig om at gøre at opløse spændingerne, at oplyse - i videste forstand at "begribe

51 - dog ikke af Svend Bjerg, der i Gud forst og sidst (2002) tværtimod opfatter Den christelige Børnelardom som Grundtvigs svar på Luthers lille katekismus. 
sig selv i Sandhed", hvad der netop er "Høiden af menneskelig Vidskab".

I GrSt 1975 spørger Christian Thodberg, om Grundtvigs nadversyn er luthersk. Brødet og vinen voldte ham problemer, for så vidt som de ikke var "indfattet" i nadverordene, men hævdede sig med egen vægt. Det ortodokse nadversyn, der hældede faretruende mod katolicismen, måtte han afvise. En overgang så han det som en opgave at modvirke, at de troende gik til alters "som Kvæget til Truget". En relativ klarhed nåede han til, da han i 1837, under arbejdet med de græske salmer, kom til at se brødet og vinen som ledsagefænomener, der skulle "præcisere 'Ordet'". Den klassiske skelnen mellem 'est' og 'significat' hævede han sig over, og Luthers løsning fandt han "lidt forvirret". 52 Han landede på det standpunkt, at "Ordet er legemligt saavelsom aandeligt og binder sig selv til Brødet og Vinen", mens Luther "blev i den indsnævring, som den katolske nadverpraxis havde efterladt ham i". Således bliver svaret på udgangsspørgsmålet, at Grundtvigs nadversyn er - grundtvigsk.

\section{Forholdet til Kierkegaard}

Også Niels Jørgen Cappelørn beskæftiger sig i et vigtigt bidrag ( $\mathrm{GrSt}$ 2004) med gudbilledlighed og syndefald, men $i^{\prime}$ en sammenligning med Søren Kierkegaard og på baggrund af Irenæus' skelnen mellem 'imago dei' og 'similitudo dei'. Groft forkortet er forholdet, at det skabte, af legeme, sjæl og ånd bestående menneske i syndefaldet mister billedet og ligheden, dog ikke så afgørende, at fuldkommenheden ikke kan regenereres ved genskabelsen, idet gudbilledet forbliver i sjælen, mens gudligheden "skal genfødes af Helligånden". Dette menneskesyn forholder Grundtvig og Kierkegaard sig til, dog ikke på helt samme vis. Grundtvigs salme "Hvor skal jeg Guds Billed finde?" giver det svar, at billedet forblev i sjælen som en genklang i ordets form, altså i sproget (med Cappelørns præcisering: "den forblevne rest af Guds billede som et reflekterende spejl i sjælen"). Til dogmetraditionens inventar hører jo også den seksuelt overførte arvesynd, som Grundtvig godtager, men som Vigilius Haufniensis gør op med i Begrebet Angest. Kierkegaard individualiserer synden, den er et udbrud af menneskelig frihed, og hvad der afstedkommes er en svimmelhed i sjælen, en syndsforvirring, der overlejrer gudbilledet, som dog på den anden side syndsbevidstheden vedblivende minder om, så

52 Jf. Erik Kelstrup (GrSt 2000): Grundtvig undgår i Kirkens Gienmoele at komme på kollisionskurs med Luther ved at antage, at dennes skriftarbejde "stiltiende forudsatte troen og dens bekendelse"; Luther var altså "underforstået enig med Grundtvig i, at troen er nøglen til skriften". 
en fornyelse kan indtræffe. Cappelørns minutiøse afvejning munder ud $\mathrm{i}$, at forskellen mellem Kierkegaards og Grundtvigs menneskesyn er overkommelig og vel beror på "deres forskellige synsfelt og hovedærinde" - Grundtvig er mere skabelsesteolog, Kierkegaard mere kristolog, Grundtvig tænker mere dynamisk og billedligt, Kierkegaard mere dialektisk og begrebsligt. I den videre diskussion af gudligheden i mennesket konstaterer Cappelørn, at hvor dåb og nadver er afgørende for Grundtvig (jf. formuleringen "ved Badet og Bordet"), er det for Kierkegaard dåb, skriftemål og altergang. Ved skriftet făr den syndsbevidste "fornyelse af gudbilledet", og ved alteret sker der "en fornyelse af gudligheden i ånd og sandhed", mens syndsforladelsen hos Grundtvig skænkes i dåben uden behov for repetition. Skriftemålet blev efterhånden for ham et tilbud om "menneskelig syndsforladelse", en art forsoning.

Forholdet mellem Grundtvig og Kierkegaard er i større almenhed blevet diskuteret i flere bidrag af Helmut Toftdahl, blandt andet i en kritisk gennemgang af "Debatten om Grundtvig og Kierkegaard" (GrSt 1969), et tillæg til hans samme år udkomne, af William Michelsen anmeldte bog Kierkegaard først - og Grundtvig så (også i GrSt 1969). Begge reagerede fra et kristent standpunkt mod den idealistiske filosofi, Grundtvig implicit i sine værker, men Kierkegaard jo med filosofiens våben. Det er fra hans synsvinkel, Toftdahl i bogen anskuer og måler Grundtvig. ${ }^{53}$ Debatgennemgangen derimod - kronologisk anlagt med udgangspunkt i Fr. Jungersens foredrag om dansk protestantisme (1873) og frem til K. E. Løgstrup og Götz Harbsmeiers Kontroverse-projekt (første bind, 1966) - lokaliserer en større tendens til grøftegravning end til brobygning. ${ }^{54}$

Om Grundtvig og Kierkegaard "som grundlæggere af en moderne social bevidsthed" handler et bidrag af Christa Kühnhold (GrSt 1988), der pointerer, at det moderne gennembrud ikke var kommet i stand uden de to - fra samtidsnormen afstikkende, vidt forskellige og på centrale punkter enige - tænkeres vejrydning. Et supplerende indlæg af

53 Vinklen er den samme i artiklen "Grundtvig og Søren Kierkegaard" ( $\mathrm{GrSt}$ 1973), hvor Toftdahl eksistentialpsykologisk vil betragte Grundtvigs værk som "en måde at have verden på", men ender med at efterlyse refleksiv skarphed hos ham. Kierkegaard kastede sig i kamp mod "dæmonerne i dødsriget" ud på de 70.000 favne, mens Grundtvig afstod fra at styrte sig ud i "det Bund-Løse". Det engelske resumé fylder godt syv småttrykte sider!

54 Artiklen behandler også Henning Høirups oversigt "Grundtvig and Kierkegaard" (1956), som ifølge Michelsens anmeldelse er underbelyst i bogen. Toftdahl giver ikke Høirup ret i, at Kierkegaards menighedsbegreb er eskatologisk. 
William Michelsen gør dog gældende, at de ikke kom til at "bestemme grundlaget" for den sociale bevidsthed efter 1872 .

\section{Forholdet til den mystiske tradition}

Hellmut Toftdahl har også belyst Grundtvigs forhold til mystikken (GrSt 1974), med polemisk sigte mod Ebbe Kløvedal Reichs "folkebog" Frederik (1972). Mystikken i kvalificeret forstand har rødder i nyplatonismens opgåen $\mathrm{i}$ enhed med Gud såvel som $\mathrm{i}$ gnosticismens ekstreme legemsforagt. Efter 1810 distancerede Grundtvig sig fra universalromantikkens himmelstormende eroslængsel og åbnede sig for agapes opaddragende kraft. Det grænseløse geni skubbes til side af "mennesket i historisk betingede begrænsninger" - hvor forskernes årstal så angiver tilpasninger og gradbøjninger.

A. Pontoppidan Thyssens artikel "Grundtvig og Spener" (GrSt 1967) er et bidrag til substantiering af den ofte upræcise snak om Grundtvigs forhold til pietismen, og den tager da udgangspunkt i centralskikkelsen P. J. Speners programskrift Pia desideria (1675), hvis synspunkter ikke blot inspirerede samtiden, men også havde betydning for 1800-tallets vækkelser. En række berøringspunkter lokaliseres. Begge kritiserede for eksempel de samtidige kirkeforhold og fordrede fuldbyrdelse af reformationen, så kirkelivet kunne komme i jævnhøjde med oldkirkens. Begge drømte, men i hver sin retning, om levende kristendom og inderlig tro.

\section{Det økumeniske perspektiv}

Peter Lodberg har i GrSt 1998 problematiseret den udbredte opfattelse, at Grundtvigs kristendom er så intimt forbundet med det nationale, at han knap nok kan finde økumenisk anvendelse. Han peger på, at flere arbejder mellem 1825 og 1848 i kirkeforståelsen betoner det universelle og økumeniske, altså før det nationale kom stærkt på banen. Hvor H. N. Clausen insisterede på "en principiel teologisk uenighed" mellem protestantisme og katolicisme, udpegede Grundtvig som altafgørende lige netop det, der forbandt alle historiens kristne. Lodberg taler ligefrem om "en katolsk-luthersk opfattelse" og minder om, at Luther for Grundtvig at se ikke havde afstedkommet "en ny Tro", men genoplivet den "oprindelige" kirke - bygget, som den var, "af levende Stene". Som den afgørende forskel fremhæver Grundtvig, at den katolske gejstlighed vil herske over samvittigheden, mens den protestantiske jo hylder princippet om de to regimenter. I sammenhæng hermed omtales savnet af dansk kirkefrihed. På denne baggrund efterlyser Lodberg "en ny besindelse på Grundtvigs forståelse af den 
gudstjenestefejrende menighed", så den kan indgå i "den aktuelle økumeniske læresamtale". ${ }^{55}$

Også A. M. Allchin har beskæftiget sig med økumeniske aspekter i Grundtvigs teologi (GrSt 1989-90). Med udgangspunkt i den intime forbindelse mellem salme, prædiken og ritual foretager han en sammenligning med andre "betydelige repræsentanter fra kirkehistorien". 56

\section{Andre bidrag}

C. I. Scharling gør i sin omfangsrige artiklel "Kristi Genkomst og Kødets Opstandelse" (GrSt 1950) rede for det eskatologiske hos Grundtvig. Det spillede for ham en vigtigere rolle end for samtiden, og jo på trods af, at han (efter 1825) stærkt betonede livet i menigheden her og nu. Han opfattede også, hvad der skulle ske på den yderste dag, i et andet lys end for eksempel de middelalderlige freskofremstillere, og i en art kontinuitet med denne verdens livsalighed. Måske så han som yngre en parallel i myten om Ragnarok, den gamle jords undergang og den fornyedes opstigen af hav?

Harry Aronsons systematiske studie i Grundtvigs teologiske tankeverden, Mänskligt och kristet (1960), der vil levere "en immanent tilstandsbeskrivelse" af forfatterskabets tankeverden, anmeldes af Henning Høirup (GrSt 1960), der trods mange kritiske anmærkninger - for eksempel i forbindelse med, at vigtige Luther-begreber frakendes "central funktion", og at salmerne lades ude af betragtning - dog finder den så "indgående og ansporende", at den er "en landvinding for forskningen". Undersøgelsen omfatter produktionen efter ca. 1830, hvor forholdet mellem titelbegreberne så nogenlunde ligger fast.

Hvor litteraturhistorikeren Lundgreen-Nielsens Det handlende ord fik kritik af teologen Thodberg for svagheder udi teologien, fik teolo-

55 Jf. Gordon W. Lathrops bidrag til GrSt 2000, der lægger en danskamerikansk kirkeklokketekst ("Til badet og bordet, / Til bønnen og ordet, / Jeg kalder hver søgende sjæl") ved siden af Pius X's 1903-løsen om aktiv deltagelse $\mathrm{i}$ de hellige handlinger - og får "a vital agenda for continuing ecumenical liturgical reform" ud af det.

56 Jf. Hans Henrik Boas, "Sammenhængen mellem Skaberånd og Helligånd i Grundtvigs teologi” (GrSt 1993), der bygger på salmer og prædikener 183239. Idet Gud udtaler skaberordet og blæser liv (livsånde) ind i mennesket, kommer det $\mathrm{i}$ besiddelse af skaberånden, og ved dåben modtager det helligånden, der er "til stede i Ordet". - I et bidrag til GrSt 1998 ("The Holy Spirit in the Teaching of N. F. S. Grundtvig") beskæftiger A. M. Allchin sig med forholdet mellem ånd og legeme i Grundtvigs teologi i et par Danne-Virkeartikler og nogle prædikener. Således afdækkes "den grundtvigske teologis patristiske præg”, der (angiveligt) “muliggør en økumenisk læsning” af ham. 
gen Helge Grells Skaberordet og billedordet (1980) i GrSt 1982 kritik af litteraturhistorikeren Hellmut Toftdahl for at være "mere på bølgelængde med den analyserende Grundtvig end med den digtende forkynder af evangeliet" og for at se bort fra forfatterskabets poetiske udvikling i den behandlede periode, 1807-32. Grells anliggende er sammenhængen mellem skabelsestanke og "problemet om Gudsordets erkendelighed". Eftersom mennesket "er skabt i tid og rum", må "det evigt-åndelige" vise sig for det "i timeligt-sanselige billeder". Men hvordan legitimerer sandheden sig i forkyndelsen, hvornår er for eksempel Grundtvig en guddommeligt inspireret prædikant, og hvornår er han - med Kierkegaards udtryk - "en brølende Grovsmed"? Grells bidrag til præciserende indholdsbestemmelse af gængse udsagn blev videreført i Skaberånd og folkeånd (1988), som sammen med forgængeren udgjorde hans disputats, og som satte fokus på Grundtvigs "tanker om folk og folkelighed $\mathrm{i}$ deres forhold til hans kristendomssyn".

"Adskillelse og vekselvirkning" er titlen på en udredning af Theodor Jørgensen om Grundtvigs syn på og påståede sammenblanding af folkelighed og kristendom ( $\mathrm{GrSt} \mathrm{1986).} \mathrm{At} \mathrm{adskille} \mathrm{er} \mathrm{nødven-}$ digt allerede af den grund, at kristendommen principielt er verdensomspændende, mens folkeligheden kun gælder "i en krog af verden og for en tid". Kristendommen bør tjene folkeligheden, ikke tvinge den - og omvendt, skønt det knap nok nævnes. Radikal adskillelse forsikrer netop mod tvang, når det gælder "erkendelse af sandhed". Folkeligheden lader sig forstå "åndeligt" og meget omfattende, lig med menneskelighed. Vekselvirkningen kan i det perspektiv ses som "Guds møde med sig selv i sin skabning". Den må gå begge veje, altså bero på en forståelse af "menneske først - kristen så", der ligesom overvinder den tidsfølge, der ligger i formlen.

I GrSt 1992 fremlægger Theodor Jørgensen en læsning "i et nutidigt perspektiv" af Kirkens Gienmoele. Fire grundtvigske synspunkter fremdrages "som typiske for nutiden". Det drejer sig om troen som erfaringssag, og vel at mærke er det med hjertet, at mennesket erfarer "den venlige vekselvirkning mellem kristendom og menneskelighed"; og om troen som vishedssag, hvor umiddelbarheden så at sige reddes ved, at Kristus selv er formidleren; og om kriteriet for kristen identitet, der beror i selve gudstjenesten; og endelig om forholdet mellem kirke og teologi, hvor kirken er forpligtet på (tros)formidlingen, mens teologien må tage sig af (livs)oplysningen.

"Vad sanning är, får tiden visa", mottoet for Verdenskrøniken 1817, er også titlen på Tord Ehnevids gennemgang af Grundtvigs sandhedsetik (GrSt 1998), der knytter sig supplerende og uddybende til Grundtvig-analysen i hans 1969-disputats om forsamlings- eller me- 
nighedsetik (også hos to yngre teologer, Einar Billing og Morten Pontoppidan). ${ }^{57}$ Det afgørende for Grundtvig er lyset over livet og tiden, som der står i et digt fra 1851. At opsøge forfatterskabets billeder af tiden er da artiklens ærinde. Ygdrasil er et sådant billede, tidens træ og følgelig historiens og livets. Ganske mange billeder har affinitet til havet og dets repræsentationsformer i nordisk mytologi - et mere komplekst billedsæt end vist af Merete Bøye (jf. ovf.). Ordet skabte tiden med dens "før" og "siden", og i tiden ses Guds spor og dermed menneskets. Det forbliver altsammen gådefuldt, først ved tidens ende opstår klarheden og sandheden, gådeløsningen. Indtil da er mennesket henvist til at søge sandheden $\mathrm{i}$ gådespejlet, hvilket også vil sige $\mathrm{i}$ "Sagas Speil", det vil sige i historien. Erkendelsen er stykkevis og delt. I 1832 vender Grundtvig tilbage til opfattelsen fra før Optrin af Norners og Asers Kamp, at mennesket er Skaberens spejl - hvilket Ehnevid i sin disputats omtaler som "en spegelvändning". Nogenlunde fast ligger derimod funderingerne i Verdenskrøniken fra 1814 om syn og ord. Ordet er bærer af sandheden, synet er anskuelse af sandheden, fornuften kan begribe sig selv i sandheden, men ikke komme ud over det timelige - det poetiske og profetiske sprog fører derimod videre mod den endelige klarhed ansigt til ansigt. Hvad sandheden er, vil altså tiden vise. Hvad etikken angår, så vedrører den for Grundtvig i alt væsentligt de ti bud, af hvilke jo ét omhandler falsk vidnesbyrd mod næsten. Den sandhedselskende historieskriver bærer ikke falsk vidnesbyrd om de folks liv, som han skildrer. Mennesket kan ikke forstå eller bevise sandheden, men dog bevidne den. Ehnevid beholder ret i, at etikken hos Grundtvig "är förknippad med tiden och sanningen på ett svårbegripligt sätt", han lader Thaning beholde ret $\mathrm{i}$, at Grundtvigs filosofi "är omedgörlig i etisk avseende", og han lader Grundtvig få det sidste ord ved at citere dele af 1856-digtet "Tidens Fylde" - om Ordet, der i tidens løb vil forklare alt og ved tidens ende åbenbare alt.

Om Guds Ord, som det er besunget af Grundtvig, handler et essay af Uffe Hansen (GrSt 1975). Hvad det egentlig betyder, at Ordet har magt til for eksempel at skabe, handle og virke, optog ham hele livet og fandt, især i salmerne, talrige markante udtryk. Livsordet lyder ved badet og bordet. Kirkeordet gennemtrænger menighedslivet. Skriftordet er, skønt menneskeværk, gennemtrængt af ånd, og altså et underværk. Men først og fremmest er det Guds levende røst, der skaber "de Levendes Lyst". ${ }^{8}$

57 Den 54 sider lange afhandling er skrevet "för 25 år sedan" - og tager ikke hensyn til senere fremkommet forskning.

58 Til den teologiske emnekreds knytter sig også nogle sammenlignende studier. David Jasper og A. M. Allchin bringer Grundtvig i forhold til den samtidige engelske digter Samuel Taylor Coleridge (GrSt 1991 og 1992), 
Som bekendt fordrede Grundtvig i 1825 , at H. N. Clausen nedlagde sit universitetsembede - på hvilken måde han bragte sig selv i en sådan klemme, at han måtte nedlægge sit præsteembede. Først i 1832 indså han, at man altid bør "unde Næsten samme Frihed, som Man selv gjør Krav paa". I GrSt 1991 har William Michelsen skildret "Vejen fra tvang til frihed i Grundtvigs liv og forfatterskab". Tvangen var der fra starten, idet forældrene mente, han skulle være præst, og jo i 1810 pressede ham til at blive kapellan i Udby. Michelsen søger begrundelserne for Grundtvigs dispositioner i forbindelse med præsteansættelserne. Han spørger blandt andet, hvornår Grundtvig erkendte, at han havde gjort uret mod Clausen - og konstruerer det svar, at det var under samtalen med Clara Bolton. Indrømmelsen var jo i øvrigt ledsaget af et forslag om mulighed for at udtræde af statskirken og etablere sig som frikirkepræst, således som John Wesley havde gjort det i England. ${ }^{59}$ Men i Danmark ønskede man ikke engelske tilstande.

I GrSt 1991 finder man tillige en artikel af Henrik Wigh-Poulsen om Grundtvigs helligåndsteologi set i forhold til engelsk romantik, især William Wordsworth og hans blæsevejrsmetaforik. Lake District's "gentle breeze" (i "The Prelude", henvendt til kollegaen Coleridge) afstedkommer hos den inspirerede digter "et ustyrligt, skabelsessvangert stormvejr med løfter om poetisk nybrud". Grundtvig taler i sit præludium til "Roskilde-Saga" om en åndelig viften - helligånden genererer indbildningskraften, der genkendende videreformidler de billeder, hvis betydning er lagt fast $\mathrm{i}$ og med skabelsen. Dog kan han gribe sig i at frygte indbildningskraftens "afgudsskabende potentiale": hvis er brisen egentlig, Helligåndens - eller hans egen? Rivegildet er afspejlet i "Paaske-Liljen", hvor det ender godt: indbildningskraften sættes i tjeneste hos historien. Men først da han fik kirke og gjorde sin mageløse opdagelse, ja, først for alvor i 1837, med Sang-Vark til den danske Kirke givet menigheden i hænde, følte han sig på decideret

Hans Henningsen udpeger ligheder og forskelle mellem natur- og historiesynet hos Grundtvig og K. E. Løgstrup (GrSt 1994), R. William Franklin reflekterer over ligheder mellem Grundtvig og den samtidige tysk-katolske teolog J. A. Möhler (GrSt 1996, med vedføjet kritisk anmærkning af William Michelsen), og Betina Hjorth Præstegaard finder lighedspunkter mellem Grundtvig og den nulevende tyske teolog Jürgen Moltmann, især hvad angår deres kritik af "den vestkirkelige teologis gudsbillede" ( $\mathrm{GrSt}$ 2002).

59 Jf. Niels Henrik Gregersens artikel om frelsens betingelser hos Grundtvig og metodisten John Wesley (GrSt 2004), der især finder "substantielle teologiske ligheder" i synet på nåden og den frie vilje. Wesleys "imødekommende nåde" markerer et opbrud fra den reformatoriske tradition. Også Grundtvig mener (i Den christelige Børnelcerdom), at der er plads for menneskets ja og nej, helt bogstaveligt i dåben, der jo er en aftaleindgåelse, hvor andet led er den døbtes eget ja, som "skal være ærligt ment", ikke blot udtalt på skrømt. 
vinderkurs. "Han bevæger sig ubesværet rundt her i sit livs pinse som en sjældent fuldvoksen romantiker [!], en hjemkommen til virkeligheden, menigheden og det ubesværede modersmål". Åndesus med orgelbrus!

Siden Danne-Virke ifølge William Michelsen udgør "fundamentet for Grundtvigs tænkning", og siden videnskabernes hovedopgave i den forbindelse er "at give en nærmere bestemmelse af, hvad et menneske er", udfolder hans introduktion i GrSt 1985 og 1986 sig som en udredning heraf, i lyset af et forarbejde om den menneskelige tænknings grænser, hvis ærinde er at sætte skel mellem religion og filosofi, netop i modsætning til samtiden og specielt Schelling. ${ }^{60}$ Tidsskriftet etablerede, som titlen antyder, et værn mod tysk filosofi og teologi. Programartiklen "Om dansk Poesie, Sprog og Historie" giver Grundtvigs første præcisering af det ægte danske - det nye var "at være dansk uden samtidig at være nordisk". ${ }^{61}$ Introduktionens anden del pointerer indledningsvis, at de "fundamentale begreber" i Grundtvigs tænkning er "sans, vidskab og gudbilledlighed". ${ }^{2}$ At forstå hans betragtninger - i Danne-Virke-artiklerne såvel som i den paralleltforfattede VerdensKrønike 1817 - stiller det krav til moderne læsere, at de "forsøger at tænke selv udfra det standpunkt, Grundtvig stiller os på: erfaringens, den sunde menneskeforstands og det danske sprogs standpunkt". Michelsen yder imidlertid god hjælp. Han gør det klart, hvordan Grundtvig gennem kritik af 1700-tallets systematiske filosofi, især Kant, rydder pladsen for historievidenskaben, fremtidens grundvidenskab, som netop afviser muligheden for at forklare mennesket og dens eksistens fornuftsmæssigt og uden at agte på de af tid og rum satte begrænsninger.

60 "Grenzen der Menschheit" (GrSt 1984) er et led i Grundtvigs opgør med den schellingske naturfilosofi eller en tendens i denne, som kan føres tilbage til gnosticismen. - Også Horst Nägele, "Warum wir uns mit N. F. S. Grundtvigs idealismus-kritischen Abhandlungen beschäftigen" (GrSt 1995), vedrører Schelling-kritikken.

${ }_{61}$ I Liselund-foredraget "Om Grundtvigs menneskesyn" (GrSt 1987) giver Michelsen en syntetisk fremstilling af Danne-Virke-introduktionen ud fra den beskæmmende konstatering, at "enhver religion kan synes at måtte være intolerant over for anderledestænkende og anderledestroende, hvis dens tilhængere er oprigtig troende" - et forhold, som dog Grundtvigs udvikling dementerer, til gunst for den danske folkekirkes rummelighed og den religiøse frihed.

${ }^{62}$ Begrebet "sans" danner basis for Grundtvigs psykologi, jf. Villiam Grønbæk, Psykologiske Tanker og Teorier hos Grundtvig (1951). Begrebet "gudbilledlighed" hviler på en tolkning af bibelordene om at "være skabt i Guds billede"; tanken udredes i Verdenskrøniken (1814-versionen), hvorfra de relevante sider aftrykkes forrest $i$ årgangen. 
I GrSt 1988 har Helge Baden Nielsen anlagt et skabelsesteologisk perspektiv på Danne-Virke. Grundtvigs synspunkt var, at mennesket er skabt i Guds billede, og det fastholdt han som "en grundlæggende sammenhæng, en indre konsistens" hen over alle tilsyneladende skred. Anlagte litterær- og udviklingshistoriske analyser (Lundgreen-Nielsens, Thanings) går fejl af, "hvad der egentlig er på færde" i Grundtvigs tidsskrift, at han lever og ånder i det bibelske univers og for at levendegøre det. Udviklingen beror på, at erkendelsen uddybes og kommer til at inddrage stedse større dele af erfaringsverdenen, at han "vandrer fra klarhed til klarhed". Opgøret med den idealistiske filosofi beroede på en forståelse af, at kristendommen simpelthen ikke behøvede den - Luther gives den lov, at han var mand for "at ride Aristoteles til Vands". Grundtvigs skabelsesteologiske alternativ er ikke-systematisk. Danne-Virke-artiklerne er en række forsøg på at løse det eksisterende menneskes uløselige gåde, en praktisering af historisk "Vidskab" så at sige.

Grundtvigs sondring mellem tro og anskuelse i mytologi-indledningen 1832 behandles af K. E. Bugge (GrSt 2006). Anskuelsen gælder jo, hvad man i teologisk henseende bør kunne enes med naturalisterne om, mens troen er det, som unddrager sig mægling. Man kunne gå i skole sammen, men knap nok i kirke. Men komplicerende nok er anskuelsen tvedelt, den omfatter ikke blot tanken om en skabelse, men også tanken om et syndefald, eller i forsigtig tale: et uheld, en vildrede. Bugge spørger nu, hvor sikker Grundtvig kunne være på, at de samtidige læsere forstod dette og henvender sig desangående til blandt andet faderen Johan Grundtvigs katekismusforklaring fra 1779 og onklen N. E. Balles autoriserede lærebog fra 1791, der fik "en betydelig udbredelse" - og får bekræftet, at talen er om "normalteologiske forudsætninger", om "naturlig", fornufts- og erfaringsbaseret teologi, hvor den "åbenbarede" jo er skriftbaseret.

Kim Arne Pedersens licentiatforelæsning "Metafysik og åbenbaring" (GrSt 1995) analyserer "de triadiske, respektive trinitariske strukturer" i Grundtvigs tænkning 1812-15, blandt andet på grundlag af et manuskriptudkast betitlet "Om Troen og dens Indflydelse paa Jordlivet eller Om Stat og Kirke". ${ }^{63}$ Pedersen finder, at "forskningens påvisning af Grundtvigs teologiske orientering mod det historiske og mod den menneskelige erfaring har fat i en lang ende". Sluttelig placerer han sig inden for "den prenterske udgave" af den tolkningstradition, som betoner vekselvirkningen mellem menneskeliv og kristendom snarere end adskillelsen (Thaning) - og undervejs argumenterer han for "en tredje fortolkning" i forhold til de gængse opfat-

63 Jf. i samme årgang en nødtørftigt kommenteret udgivelse af udkastet (til et svar på Jens Møllers anmeldelse af Verdenskrøniken af 1812). 
telser af Grundtvigs tænkning: som en slags trosfilosofi (Høirup, Michelsen) og som en naturlig gudserkendelse (Grell). Dette blandt andet med henvisning til, at Grundtvig selv (i korrespondancen med Stener Stenersen) bekendte sig til en "naturlig teologi" med plads til både troen og erkendelsen. Den traditionelle, hos Platon genererede tredeling ånd, legeme og sjæl forbinder han som bekendt med erkendeevnerne indbildningskraft, følelse og forstand. I det behandlede tidsrum "er det evident, at den guddommelige trinitet belyses gennem den menneskelige triade", nemlig i medfør af gudbilledligheden. Inspirationen er næppe Schellings triadetænkning - Prenter har peget på Augustin, men Pedersen nævner en kilde tættere på, nemlig 1700talsteologen P. Rosenstand Goiske. I øvrigt inddrages forholdet til treenighedslærens udformninger i protestantisk teologi (Gud som tre personer eller som ét subjekt omfattende tre eksistensformer). Pedersen kan konkludere, "at Grundtvig med den naturlige teologi som afsæt opererer med en trinitetsteologi, der tænker skabelsesteologi og metafysisk gudserkendelse sammen med de menneskelige, triadiske strukturer, eller rettere, den ene, afgørende triadiske struktur, som udgøres af erkendeevnerne følelse, indbildningskraft og fornuft". ${ }^{64}$

"Grundtvig som kontextuell teolog" er emnet for et bidrag af Anders Holmberg i GrSt 1996, som fokuserer på Grundtvigs danske virkningshistorie ud fra den brede definition af den overvejende angelsaksiske kontekstuelle teologi, som skyldes S. B. Bevans. Til de præsenterede modeller, der alle drejer sig om forholdet mellem kristen tro og kulturen i det omgivende samfund, stiller Holmberg en række spørgsmål, inklusive det afgørende, om Grundtvigs teologi er kontekstuel "enligt denna modell". Hvad den så langthen viser sig at være - men måske blot, fordi undersøgelsesobjektet "har en uvanligt mångfasetterad kontextualitet".

"Menneske først -" er titlen på et bidrag af K. E. Bugge om Grundtvig og hedningemissionen (GrSt 2001) - og jo altså på et berømt Grundtvig-digt skrevet tidligt i 1837 i protest mod en Heinrich Müller-tekst, men næppe i forlængelse af formuleringer hos Hans Egede og Holberg. Hans udgangsposition var datidens almindelige, at apostlene stort set havde udført missionsbefalingen, men at der i praksis bestod en forpligtelse over for hedninger inden for den danske magtsfære, jf. pietismens initiativer, først og fremmest jo Hans Egedes Grønlands-indsats (to af Grundtvigs brødre blev som bekendt udsendt til Guldkysten og døde dér). Men først efter 1825, og især i de to afhandlinger om sand kristendom og om kristendommens sandhed gør han endeligt op med det ortodokse syn på hedningemission. Opgaven

64 Jf. Pedersens præsentation af Regin Prenters afhandling om Grundtvigs treenighedslære i GrSt 1992. 
er universel, men må gribes rigtigt an - ordet må forkyndes, men "til fri afgørelse". J. C. Lindbergs Nordisk Kirke-Tidende debatterede sagen stort set på dette grundlag og gav Grundtvig indblik i aktuel praksis - og anledning til at reagere, som imod Müllers andagtsstykke "Intet Menneske, ingen Christen".

I "Grundtvig og fundamentalismen" (GrSt 2005) dykker Kim Arne Pedersen ned i det spørgsmål, som i de senere år har trængt sig på: om Grundtvig var "fundamentalist", i hvert fald mellem selvopgørene i 1810 og 1824-25. Med Ole Vinds 1999-disputats rykkede synspunktet for alvor ind i Grundtvig-forskningen. Pedersen knytter det teologihistoriske fundamentalismebegreb til den reaktion mod liberalteologien, som havde medvind i det amerikanske bibelbælte for 100 år siden (dengang som nu blandt andet for at få ulovliggjort skoleundervisning i den darwinistiske udviklingslære), og som - også takket være den karismatiske bevægelse - opnåede en revival sidst i århundredet. Pedersen arbejder også med en profanhistorisk definition, knyttet til reaktionen mod moderniteten - og dermed traditionsnedbrydningen, opsplitningen osv. - i industri- og kommunikationssamfundet. I begge tilfælde forudsættes "en moderne tænkemåde, som fundamentalismen opstår i protest mod" - med det forbehold, at sekulariseringsmodstand nok ofte er et rimeligere begreb at anvende. Ole Vind pointerer, at Grundtvig læser Bibelen bogstaveligt, og at han også efter det andet selvopgør fastholder, at den er om ikke dikteret, så dog inspireret af Gud. Pedersen anfører, at Vind "formodentlig" er bevidst om sit brud med "det officielle billede af Grundtvig", at det levende ord kommer før det skrevne. Men hvad angår selvopgøret $\mathrm{i}$ 1810, som Pedersen fintfølende rekonstruerer, ligger han på linje med Vind, for så vidt som opgøret "kan og skal forstås som en klassisk omvendelsesoplevelse i forlængelse af den individualistiske vækkelseskristendom, som præger 1700-tallets lutherske pietisme" (og erindrer om USA-fundamentalisternes fordring om personlig omvendelse, der ganske vist skulle udvise "enshed i omvendelsen"). Og som bekendt havnede Grundtvig i læren om verbalinspiration - Bibelen var åbenbaret sandhed, indblæst af Gud og dikteret af Helligånden - med front mod den moderne videnskabs kopernikansk forankrede opfattelse af verdens indretning. Men fundamentalist er Grundtvig kun i teologihistorisk bemærkelse, ikke i profanhistorisk, blandt andet fordi han frem for at stræbe tilbage mod "en idealiseret guldalder" tænker prospektivt: folkemenighederne afløser hinanden i et forandringsforløb. Det afgørende spørgsmål er imidlertid, om den "mageløse Opdagelse" markerer en tilstrækkelig radikal omvendelse til, at fundamentalismemistanken mister enhver berettigelse. Pedersen svarer ja med henvisning især til Kaj Thanings og Christian Thodbergs eksistentielt 
funderede undersøgelser. For Thaning er det afgørende, at Grundtvig i 1824 finder sig selv som "den lyttende i forholdet til kirken", mens han ligesom Thodberg ser det som problematisk, at trosbekendelsen gøres til målestok for rettroenhed. Som bekendt er det arbejdet med Sangværket og specielt med de græske salmer, der for Thodberg forskaffer Grundtvig frihed i forhold til Skriften og muliggør et mere imødekommende syn på bibelkritikken. Grundtvig giver los også på to for Ole Vinds betragtning centrale punkter: skabelsesberetningen og Babelsfortællingen, før set som historiske, bliver til henholdsvis en forestilling, der er "baade Guddommen værdig og passende til Menneske-Aandens høieste Flugt og til Hjertets dybeste Rørelser", og et "reelt videnskabeligt" problem, der kan henlægges til skolen. I sidste ende er det dog mindre bruddet med bibelkristendommen end den $\mathrm{i}$ kirke/skole-sondringen og frihedstænkningen funderede åbning mod "naturalisterne af ånd", der frikender Grundtvig for fundamentalismebeskyldningerne.

\section{Salmestudier ${ }^{65}$}

GrSt 1949 fremlagde en efterladt Magnus Stevns-artikel om "Grundtvigs og Kingos Salmer", der bestemmer Grundtvigs forhold til forgængeren (hvis salmebog han jo skattede højere end den evangelisk-kristelige) som nærmest reaktivt. Han kommer bedst fra sine omdigtninger, hvor han må give dem en afgørende drejning. Et oplagt eksempel er "Jeg kender et Land", omskrivningen af "Far, Verden, far vel", hvor "hele den patetiske Drivkraft i Kingos Fornægtelse af Verdenslivet som Tant omkobles til Grundtvigs Bekendelse af Kærlighedsriget som sandt".

Jørgen Sørensen redegjorde i GrSt 1964 for Grundtvigs forhold til ældre dansk salmedigtning og tilføjede i GrSt 1966 en artikel om forholdet specielt til Brorson. Grundtvigs tidligste kritik af Evangeliskkristelig Psalmebog var æstetisk funderet, mens han efter 1810-krisen så fraværet af historiske salmer som tegn på teologisk armod, i Verdens Krønike med tilføjelse af, at æstetikken ikke måtte overskygge det folkelige. En tilbagevenden til Kingos salmebog var dog ikke svaret, i hvert fald behøvedes så "en med Ærbødighed ændrende Haand". Salmebearbejdelser blev det dog ikke til før efter 1832, men nok - efter udgivelsen af Kirkens Gienmoele - til efterlysning af en ny

65 Jf. Arthur Arnholtz, "Grundtvigs salmer og deres melodier" (GrSt 1952), om "den store, umusikalske, men sangkloge digters tre møder med musikken", af hvilke først det med Thomas Laub blev helt lykkeligt; hans melodier forlener teksterne med "den musikalske storhed og dybde, de fortjener". Jf. også Peter Thyssen, "Grundtvig, Laub og kirkesangen” (GrSt 1994). 
salmebog, baseret på "en sand christelig" snarere end på "en falsk tyrkisk" oplysning. At Brorson i Grundtvigs optik spillede en perifer rolle som kirkesalmedigter - hans tekster egnede sig bedst "til enkelte Christnes Privat-Andagt" - fremgår af den anden artikel. Han blev følgelig knap nok tilgodeset i de salmeprojekter, som Grundtvig involverede sig i. Psalme-Blade fra 1843, der med fokus på det "absolut nødvendige" var hans eget projekt, medtog således to Brorson-salmer. Prøvehæftet fra 1845, et kommissionsarbejde, var med sine syv Brorson-salmer mere traditionsforankret, end han kunne goutere. At de nymodens gudelige forsamlinger yndede den pietistiske forgænger, var ikke hans sag. Kun i et par år efter 1825 var han fristet til at integrere Brorson i menighedsrepertoiret. ${ }^{66}$

I sin gennemgang af "O Christelighed" (GrSt 1970) påpeger Thorkild Borup Jensen, hvordan bibelsprog omstøbes til billedsprog, og hvilke poetiske strategier digteren i det hele taget gør brug af, hvad der "gør ham til en moderne digter". Borup Jensen kommer også ind på salmens "forstadier", og herunder selvfølgelig forholdet til Kingos "Far, Verden, far vel", hvis skel mellem "jordelivets usle bedrag" og paradisdrømmen Grundtvig jo ophæver. I det følgende bidrag beskæftiger Niels Egebak sig passende nok med et af forstadierne, "De Levendes Land", der med Borup Jensens ord har "bevaret baroksalmens symmetriske opbygning, dens aksefaste og pompøse anlæg”. Egebak registrerer et spændingsforhold mellem kristendom og romantik, som forsvinder ved omarbejdelsen, en ideologibaseret versificering af "fastslåede sandheder". ${ }^{67}$

Egebaks "Om at tilskrive sig Troens rare klenodie" (GrSt 1971) fremlægger med polemisk brod mod litteraturhistoriens "sandheder" en læsning af " Hil dig, Frelser og Forsoner!" som "nutidig" - og som en tekst, der "handler om sin egen tilblivelse". I GrSt 1972 endevender William Michelsen atter salmen, i polemik mod Egebaks opfattelse af religiøsiteten i Grundtvigs salmedigtning som ideologi; det skrivende jeg udtrykker den syngende menigheds (måske vaklende) tillid til, at døden kan overkommes.

Peter Balslev-Clausen leverede i GrSt 1983 en tolkning af "Du, som gaar ud fra den levende Gud", der jo er frit bearbejdet efter en James Montgomery-salme med henblik på repræsentationen af den

${ }^{66}$ Jf. Jette Holm, “'Psalme-Blade til Kirke-Bod'. En brevveksling mellem Grundtvig og hans præstevenner i foråret 1843" (GrSt 2002).

67 Bidraget fremkom oprindelig i Fra modernisme til ny-marxistisk kritik (1970), hvor også Jørgen Bang, Flemming Harrits og Finn Stein Larsen giver bud på digtets fortolkning. - En filologisk kommentar til "De Levendes Land" (GrSt 1956) karakteriseres af forfatteren, Peter Skautrup, som en dissektionsøvelse bragt på tryk "med nogen beklemmelse". 
fjerde menighed i Sang-Vark (1837). Hovedmodsætningen mellem liv og død, lys og mørke, skabelse og fortabelse ses her fuldt udfoldet, ligesom salmen er "gennemvævet med skriftsteder" (bl.a., "næppe tilfældigt", ordene til Efesus-menigheden om "det livstræ, der skyder af korsets rod", en angelsaksisk forståelse med oldkirkelig udspring). I øvrigt kredser Grundtvig i sine samtidige prædikener om de samme spørgsmål som i salmen. Så fortolkningen kommer vidt omkring men ikke frem til en egentlig æstetisk vurdering.

"Verdenssyn og menneskesyn i Grundtvigs salmedigtning" er titlen på Balslev-Clausens licentiatforelæsning (GrSt 1989-90), der indledningsvis aktualiserer et hermeneutisk problem: hvordan kan salmerne gælde som "menighedens eksistentielle livsudtryk", når det forudsatte verdensbillede, fastholdt som "Kristendommens nødvendige forudsætning", i dag ikke kan tages alvorligt? Det beror naturligvis på det livgivende ord, genlyden af skaberordet i det menneskelige fællesskab, som det for Grundtvig udfoldede sig i en kaldæisk (ikke kopernikansk) verdensorden med oldkirkelig tidsregning, med profeter og skjalde til at fortolke "det tids- og sted-transcenderende livsfællesskab" - og med rationalistiske modstandere, der udgjorde "fortabelsens æt". Salmerne skrev han "i frontlinjen mellem liv og død", til befæstelse af den udsatte sammenhæng mellem menneskeligt og kristeligt, og dette menneskelige blev tilmed kvalificeret af dets kvindelige komponent, den milde modtagelighed, som ikke mindst Marie Toft inkarnerede. Hvordan indholdsmæssige og formelle detaljer samvirker i formidlingen, lader Balslev-Clausen "Guds Menighed, syng for vor Skaber i Løn" vidne om.

"Kristologien i Grundtvigs salmer" er i GrSt 1989-90 analyseret af Jakob Fløe Nielsen, der mener, at "udsagnene om Kristus i Sangværket forbinder sig med hverandre til en sammenhængende lære om Kristus" som den, hvis indgreb i det faldne menneskes liv kan føre det tilbage i "den livgivende vekselvirkning med Gud, hvori det alene kan vokse og forklares til den guddomsherlighed, hvortil det blev skabt".

Flemming Lundgreen-Nielsens afhandling "Sjæleøje-Stavnen eller Sjæle-Færge-Stavnen?" i GrSt 1994 - om "Gammel nok jeg nu er blevet", Grundtvigs formentlig sidste digt - former sig som en litterærhistorisk drøftelse af de i titlen markerede mulige læsninger af tredje strofes næstsidste linje efterfulgt af en minutiøs manuskriptundersøgelse. ${ }^{68}$ Der konkluderes i sjælefærgens favør, og i øvrigt finder Lundgreen-Nielsen, at digtet modsigelsesfrit kan forstås "som en forvendt Karon-myte". Imod denne udlægning reagerede William Michelsen i GrSt 1995. Han fandt den græsk-mytologiske reference malplaceret og

68 Lundgreen-Nielsens foranledning er en kort gennemgang ved Bent Noack af "Sidste Digt" i Vartovbogen, 1993. 
voterede i stedet for, at talen er om kirkens skib - en "ny" Grundtvigforestilling, da han plejede at forestille sig døden som midtpunkt i livet og kirken som et hus "bygget af levende Stene".

Lundgreen-Nielsen replicerede i artiklen "Grundtvig, angelsakserne og Sidste Digt" (GrSt 1999), der udfolder sig som en Forschungsbericht hovedsagelig med fokus på et bidrag af S. A. J. Bradley til forskningsantologien Heritage and Prophecy (1993), der udpeger en række affiniteter mellem Grundtvig og flere angelsaksiske forfattere, blandt andet mellem "Sidste Digt" og Cynewulfs selvkarakteristik i Exeter-bogen. Lundgreen-Nielsen dvæler herover for ved Ewalds betydning for Grundtvig; han var jo (som også Wessel) en anerkendt og på ingen måde en tilstøvet klassiker, der kunne vippes over ende af "den angelsaksiske styrtsø, som i 1815 ramte Grundtvig". Til Michelsen har Lundgreen-Nielsen den bemærkning, at Karon-myten er "forvendt", også hvad angår færgens destination, og Merete Bøyes insisteren på "The Seafarer" som forbillede for "Sidste Digt" giver ham anledning til pointering af, at "tesen om, at en vidt og bredt belæst og mageløs produktiv poet absolut skal have ét bestemt forbillede for et afskedsdigt med verden, passer ikke godt til Grundtvigs lange praksis". En tolkning af digtet - og af Grundtvigs synske digte i det hele taget - må være et både/og, fordi han tilstræbte at sige det usigelige "ved at kombinere og udveksle billeder fra helt forskellige perioder, litteraturer og religioner".

Diskussionen afrundes af Aage Schiøler i GrSt 2004, der i "Randbemærkninger til tre sømandssange af Grundtvig" ser sidstedigtets kirkelige anskuelse som et svar på Karon-myten. Schiøler finder motivsammenfald med to andre digte og underbygger dette. Grundmotivet er jo alt andet end ukendt, jf. Ambrosius Stubs "Livet som en Seylads", et fortumlet forehavende, hvor endemålet dog gerne skulle være frelse og forløsning, altså det modsatte af, hvad den græske myte udsiger. De grundtvigske, mangfoldigt varierede billeder er mestendels gammeltestamentlige. Hvad "Sidste Digt" angår, forestiller Schiøler sig "Noas Ark som Sjæle-Færgens prototype" snarere end Karons pram. Grundtvig, der meget vel kendte til gruen for den skelsættende istaphånd, ville i "grænsesituationen" gerne befæstes i troen på "Kiærlighedens guldprude Stad". Artiklen positionsbestemmer de tre digte og deres motiver i en omfattende billedsammenhæng på baggrund af Grundtvigs kirkelige anskuelse - "som mulig livsholdning i grænsesituationen", og forlenet med "en egenartet udsagnskraft". Digtene optager resonans fra (forholder sig intertekstuelt til) den kristne tradition i bred forstand.

Schiøler har videreført sine salmestudier i de seneste årgange. I første omgang (GrSt 2006) med fokus på "Han, som har hjulpet 
hidindtil" og "Hjertesuk efter Davidsharpen" og med henblik på brugen af de gammeltestamentlige begreber "Sjæl" og "Støv" om "mennesket som udelt livsvæsen". Over for eksistensvilkår knyttet til fænomener som mismod, frygt, overmod og skråsikkerhed og ikke mindre over for "vores yderste grænse, døden" fastholder salmerne " $\mathrm{i}$ ét greb, at der i morgen er en ny dag, og at vi ikke selv er basis for vores eksistens", og netop ved "at bruge sjæl/støv-komplementariteten til at sætte ord på sagen". Kunne Johannes Ewalds ode "Rungsteds Lyksaligheder" med dens henførte tale om det beåndede støvs bærekraft måske have fortjent en reference? Dernæst (GrSt 2007) af "Sangmotivets funktion i to tekstrettelser hos Grundtvig" - hvor de pågældende rettelser forekommer i 1868-versionen af "Blomstre som en Rosen-Gaard" og i 1864-versionen af "Midt iblandt os er Guds Rige", men hvor eksistensomsvinget (fra "Nød" til "Fryd") også billedeliggøres andre steder: af englesangen i "Et Barn er født i Bethlehem", af klokkeklangen i "Velkommen igien, Guds Engle smaa" og af menneskesangen i "Alt hvad som Fuglevinger fik". Og endelig (GrSt 2008) af "Midt iblandt os er Guds Rige" med henblik på forholdet mellem inkarnation og eskatologi. Et par japanske haiku-digte inddrages $\mathrm{i}$ en tydeliggørende bestræbelse, hvad der dog fordrer en præcision af, at buddhismen opfatter liv og død som komplementære, mens de i Grundtvigs optik er absolutte kontraster. ${ }^{69}$

Niels Henrik Gregersen gennemgår i "Mennesket som mikrokosmos" (GrSt 2000) "et både betydningsmættet og kompositorisk gennemarbejdet digt", nemlig "Menneske-Livet" fra 1847, der vedrører menneskets "mulighed for selvafklaring og vækst". Digtet lader naturfænomenerne være "sindbilleder på menneskelivet". Mennesket er et mikrokosmos i den forstand, at det rummer såvel den sanselige som den åndelige verden i sig, "det er udset til at være Guds fuldstændige skabning". Naturbillederne transformeres ned gennem digtet i en skildring af vækststadierne hen imod fuldstændigheden. Hvor menneskets "selvberoende himmelstræben" møder sin grænse, tager inkarnationen over. Gregersen sætter tankegangen i forhold til inspirationen fra oldkirken og peger på, at Grundtvig ikke kan følge den romantiske mikrokosmostænkning (jf. Steffens) i dens potensering af naturbegrebet og ej heller i tanken om, at alt består "ved en uendelig Harmonie" - kampen mellem liv og død kender ikke til våbenhvile. Hans "dobbelte" mikrokosmos ligger i forlængelse af "platonsk-kristen tradition".

Theodor Jørgensens "En Grundtvig-salme teologisk fortolket" (GrSt 2007) forholder sig konkret til "Velkommen igien, Guds Engle smaa", men gør gældende, at salmer generelt - og dermed jo også

69 Fælles for Aage Schiølers fire bidrag er, at de er ganske langstrakte (i alt 173 sider), detaljeophobende, digressionstyngede og uklare i sigtet. 
Grundtvigs - fordrer "en teologisk-dogmatisk læsning”, om de skal ydes fuld retfærdighed. Ligesom litterater opererer med tekststrukturer, taler Jørgensen om en salmes "dogmatiske struktur" - som Grundtvig evner at fylde med "menneskelig livserfaring". En sådan læsning "kan give overraskende indfaldsvinkler til det poetiske billedsprog". 70

Et kort bidrag af Jakob Balling, "Creative Recycling" (GrSt 2000), drejer sig om et par salmers forhold til deres kilder i europæisk tradition. Om "O, store Gud, vi love dig" anføres, at den er blevet "more old church, so to speak, than the source itself".

"Hyrdeliv og paradisdrøm" er titlen på Inger Lise Mikkelsens tematiske redegørelse i GrSt 1994 for Grundtvigs indplacering af hyrden i sit billedunivers. Eftersom hebraisk ikke havde fjernet sig ret meget fra "det paradisiske grundsprog", var jøderne "det mest poetiske folkefærd i historien" (og jo "en slægt af hyrder" med Abraham som drot og David med "et hjerte, der er en jordisk genspejling af Guds hjerte, som er kærlighed"). Det er hyrderne ved Bethlehem, som englene "paa Psalmens Tone-Stige" nedstiger til med budskabet om Gudsrigets komme. I salmerne om begivenheden udfoldes billedrigdommen. Krybberummet bliver til hjertekammeret, hvori Jesus den gode hyrde - tager bolig, osv.

\section{Prædikenstudier}

Interessen for Grundtvigs prædikener kom for alvor ind i billedet, da en arbejdsgruppe under ledelse af Christian Thodberg indledte det store udgivelsesprojekt, som efterhånden har resulteret i tre prædikenudgaver omfattende i alt 22 bind. ${ }^{71}$ Arbejdet foregår nu på Center for Grundtvigstudier ved Aarhus Universitet, etableret 1988 - og siden da en vigtig samarbejdspartner for Selskabet, hvilket også afspejles i årbogen. ${ }^{72}$

I GrSt 1977-78, også udkommet som bog med titlen For sammenhœengens skyld, præsenterede Thodberg en håndfuld studenteropgaver om "ord og motiver i Grundtvigs salmer og prædikener", resultater af

70 Mon det henhører under den dogmatiske læsning, at der i København næppe var julemidnatsmesser på Grundtvigs tid? Formuleringen "paa KirkeSti” bør uden videre kunne hensætte os til et andet sted og en anden tid, "mens som Barn paa Landet jeg var hjemme".

71 Prædikenerne 1822-26 og 1832-39, bind 1-12, 1983-86; Præstø-prædikenerne 1821-22, bind 1-2, 1988; Vartov-prædikenerne, bind 1-8, 2003-07.

72 Jf. GrSt 1989-90, forordet, der oplyser, at samarbejdet "indledtes i september 1989 ved et møde på Sandbjerg Slot”. Foredragene ved den lejlighed indgår i dobbeltårgangen. 
bestræbelser indledt af ham selv med skriftet En glemt dimension $i$ Grundtvigs salmer (1969) - og videreført traditionshistorisk i hans afsluttende bidrag til bogen, om Christian Hostrup som prædikant med henblik på "de grundtvigske elementer". ${ }^{73}$ En række hjerteord i Sangværket lokaliseres i artiklerne og bringes i spil i analyser af billeddannelser og -betydninger, der fra salmerne rækker ind i prædikenerne (eller rettere: findes begge steder, men markantest i salmerne, mens prædikenerne udgør eksperimentariet, hvor klarheden skrives og tales frem). For eksempel forekommer "hjerte" 1723 gange i Sangværket, og vel at mærke ofte i ordkonstellationer og betydningsmønstre, der går til hjertet også i Grundtvigs forkyndelse. Helge Toldberg var selvfølgelig på det rene med denne grundtvigske billeddannelse, men her udvikles altså en metode, der rækker videre end den af Peter Brask udviklede (Tekst og tolkning, 1973), helt over i Grundtvigs teologiske praksis og praktiske teologi. - Lise Helweg redegør med udgangspunkt i håbssalmen "Vor Herre! til Dig maa jeg tye" for en hidtil upåagtet struktur, den såkaldte v-struktur, som siden er eftervist andre steder, men som for resten kan være svær at få øje på i reducerede salmebogsversioner. - Andre undersøgelser vedrører hele begrebskomplekser og emnefelter (væksttanken, nadverelementerne, med videre). Men også her går bevægelsen altså fra ordene til Ordet, det kvalificerede skaberord, som det høres ved dåb og nadver. ${ }^{74}$

Som spin-off af dette arbejde har GrSt offentliggjort en række kommenterede prædikener og overvejelser af forholdet mellem prædikener og salmer, så meget mere som Thodberg har udviklet et synspunkt på prædikenerne som en slags prosadigte, der blot ikke er "brudt op". For eksempel præsenterer Jette Holm i GrSt 1997 både en prædiken, der på dagen for Christian VIII's kroning i 1840 udviklede forskellen på helligånd og folkeånd, og en gennemgang af salmen "At sige Verden ret Farvel" set i lyset af de samtidige prædikener.

Ligeledes i GrSt 1997 beskæftiger Jørgen Ertner sig med "Sov sødt, Barnlille" under tilblivelsessynspunkt. Og i forbindelse med

73 Hostrup-bidraget drejer sig egentlig om grundtvigiansk forvaltning af arven. Hostrup romantiserede og idylliserede Grundtvig. For eksempel er opvækkelsen hos Grundtvig "et dramatisk brud", hos Hostrup "en harmonisk overgang". Hjertet er de religiøse erfaringers sted, ikke spejl for Gudskærligheden og klangbund for Gudsordet. Men eftersom Thodberg i forhold til Hostrup - såvel som Grundtvigs elever i forhold til ham - lægger vægt på samtidige præmisser, må han trods alt tilskrive ham virkelighedstroskab og oprigtighed og erkende som historisk faktum, at Hostrup-prædikenerne hvad angår sproglig form ikke fandt deres lige i 1800-tallets senere del.

${ }_{74}$ En principiel bemærkning til projektet er Kai Ryhede, "Videnskab eller helgendyrkelse?", Prcesteforeningens Blad, 1978, 228-30, overset af Grundtvig-bibliografien 1986. 
offentliggørelsen af Vartov-prædikenerne bidrog Christian Thodberg til GrSt 2005 med en artikel om Grundtvigs depression i 1844, især med henblik på salmen "Sov sødt, Barnlille". I gæld til Ertner bragte han salmen i forhold til specielt den storartede prædiken, som Grundtvig holdt lige før rekreationsrejsen ud i det sjællandske, og som aftrykkes efterfølgende sammen med nogle breve. Artiklen argumenterer for, at salmen har "spillet en afgørende rolle i udviklingen af Fadervors betydning for Grundtvig".

"Grundtvigs skovoplevelse i 1811 og prædikenerne over Peters fiskedræt i tiden, der fulgte" er emnet for en længere afhandling af Thodberg i GrSt 1986. Oplevelsen, skildret i digtet "Farvel til Sibbern", indtraf på vejen fra København til Udby, hvor Grundtvig jo skulle assistere faderen. Siddende på en sten læser han en passus fra Korinterbrevet, hvorved mismod forvandles til fortrøstning. Nøjere forklaring finder Thodberg i en prædiken fra 1833, der rekapitulerer oplevelsen - og forbinder den med Jesu ord til Peter. Fiskerlivet billedliggør forkyndergerningen, den at udkaste garn og fange mennesker. Efterfølgende undersøges samtlige Grundtvigs bevarede prædikener til den samme trinitatissøndag. Ved flere lejligheder får de prosalyrisk karakter - og opsætning. Endda afsøges "De Levendes Land" for reminiscenser af skovoplevelsen - "det lønner sig gang på gang at forsøge en meget kontant tolkning af Grundtvigs billedbrug" - og selvfølgelig også stroferne i "Nyaars-Morgen" om vækkelsen dengang: "Saa lød fra det Høje, / Hvor stille jeg sad, / Med Ordet for Øje, / En Røst over Blad". I 1840-prædikenen knytter Grundtvig selv en forbindelse mellem den mageløse opdagelse og skovoplevelsen; begge har åbenbaringskarakter.

I GrSt 1998 bringes et bidrag af Thodberg om Grundtvigs brug af Det gamle Testamente i prædikener og især salmer. Digteren manøvrerede frit i bibeluniverset og kunne vel 1736-oversættelsen udenad, men en pointe er, at han som "en Stymper i Jødelæsning” gerne søgte inspiration i Septuaginta, hvad Thodberg blev opmærksom på, da han i "Blomstre som en Rosengaard" stødte på nævnelsen af "Jordans øde Slette", hvortil 1736-versionen intet modsvar har. Salmen eksemplificerer tillige den v-struktur, som blev fremanalyseret i flere af bidragene til For sammenhoengens skyld - mens "Hyggelig, rolig" fremdrages som særlig illustrativ for Septuaginta-indflydelsen.

75 Jf. en senere Thodberg-artikel, "Grundtvig og Gammel Testamente - den danske Bibel eller Septuaginta?" (GrSt 1998), som uddyber og udvider synspunktet. Grundtvig fandt Septuaginta mere poetisk end Christian VI's bibel. I øvrigt er en række af Thodbergs tidlige afhandlinger, inkl. bogen fra 1961, samlet i Syn og sang. Poesi og teologi hos Grundtvig (1989). 
I GrSt 2000 diskuterer Thodberg Grundtvigs forhold til den liturgiske eksegese. Da oplysningsteologerne ville pille de "kraftige gerninger" ud af det fra romerkirken traderede tekstrækkesystem, måtte han protestere. Det nagende spørgsmål om, hvor Gud talte personligt og direkte til ham, fandt han som bekendt svar på i dåbs- og nadverordene, men han undgik, at prædikenen i samme åndedrag blev sat i skygge efterdi ritualordene jo ret beset svarer til "den centrale apostolske forkyndelse". Evangelieteksten om enkens søn fra Nain sagde ham det tilstrækkelig klart: "Ved at lade ritualordene udtrykke de kraftige gerninger, som Jesus gjorde dengang, făr Jesu kraftige gerninger $n u$ en utvetydig personlig adresse". ${ }^{76}$

Om "den eskatologiske spænding i forståelsen af Guds rige" handler et længere bidrag af Elisabeth Albinus Glenthøj til forståelse af Grundtvigs teologiske udvikling frem mod 1824 (GrSt 1995). Spændingen (mellem det $\mathrm{i}$ troen og håbet nærværende Gudsrige og det, der ved Kristi genkomst vil synliggøre sig) gør sig bemærket i Præstøprædikenerne og forankres i de følgende par år i teologien. Udviklingen følges i prædikenerne og når i mål i "De Levendes Land", der følgelig analyseres på grundig teologisk vis ("Templet af Muld" omtales for eksempel over godt to sider) med fokus på evighedslængslen, som ikke mennesket selv, men Gud kan levere svar på. Grundtvig, der ifølge dagbogen 5. december 1805 tumlede om på det vildene hav uden "at have et Land i Sigte", har i "De Levendes Land" fået fast grund under fødderne.

Endelig må nævnes en gennemgang ved Peter Neergaard Jessen af Grundtvigs Vartov-prædikener i skæbneåret 1864 (GrSt 1997). Afståelsen af de sønderjyske landsdele havde han allerede under den første slesvigske krig set i øjnene som opspil til rigets undergang. Prædikenerne reflekterer nu ulykken i dens fremadskriden, danskhedens udsivning, men også troen på, at Gud holder hånden skærmende om det livshigende folkehjerte, vist ud fra oplevelsen i årene forud af tegn på kristen vækkelse.

\section{Grundtvig som politiker}

Man kan med rimelighed anskue Grundtvigs folkelighedsbegreb, analyseret og diskuteret af Balder Mørk Andersen i GrSt 2003, som klangbund eller incitament for hans deltagelse i praktisk politik. Det iboende

\footnotetext{
76 Allerede $\mathrm{i}$ forordet til Grundtvigs 1834-prædikener pointerede Christian Thodberg det ejendommeligt personlige i just denne prædiken. Jf. hertil Kaj Thanings bidrag "Enkens søn fra Nain" i GrSt 1989-90. Grundtvig minder sin menighed om en ældre prædiken over teksten - og de to forskere byder forskelligt ind på, hvilken der er tale om.
} 
element af danskhed varierer, ifølge Flemming Lundgreen-Nielsen med højdepunkt i Skamlingsbanke-talen 1844, men i øvrigt under indtryk af skiftene i det tysk-danske forhold. Hvad angår relationen mellem folkelighed og kristendom, er forskerne uenige, langthen fordi Grundtvigs egne udsagn svinger. Den "folkeånd", der som en anden helligånd svæver over vandene, indebærer blandt andet fælles tænkemåde, historiefølelse og offervillighed. Fædreland og modersmål $\mathrm{i}$ inderlig omfavnelse er et gennemgående tema i taler og sange. Men den fare lurer jo, at "et Folks Fædernelands-Kiærlighed" kan slå over i "Ligegyldighed for Menneskeheden" og "Hadskhed, Ubillighed og Uretfærdighed mod de Fremmede og især mod Naboerne", en fare, som Grundtvig knap nok selv undgik, jf. talen om det udvalgte folk (efter 1864 dog et folk "af de smaa"). Mørk Andersen nævner også, hvordan synet på Grundtvigs "Fædrelanderi” spænder fra Georg Brandes' affærdigelse til for eksempel P. Neerup Buhls inddragelse af det $\mathrm{i}$ danernes aktuelle korstog mod muhamedanerne. ${ }^{77}$

Skønt Grundtvigs interesse for politik gik langt tilbage, faldt hans politiske indsats sent. Grundlæggende er i denne sammenhæng et frihedsbegreb afgørende præget af engelsk liberalisme, således som Kaj Baagø har dokumenteret det i GrSt 1955 - via-à-vis William Michelsens pointering af, at Grundtvigs opfattelse blev fastlagt af K. L. Rahbek i 1804. Adam Smiths og især Jeremy Benthams tænkning lærte Grundtvig at kende o. 1830 blandt andet gennem sin engelske kontaktperson John Bowring, en nær ven af Bentham. Det gamle ubehag ved fransk-revolutionære og tysk-idealistiske frihedstanker afløstes af et nyt frihedssyn, der "fulgte de simple engelske liberale ideer: at kæmpe mod ethvert regimente, som indskrænker den personlige frihed". Religionsfriheden blev suppleret af konkurrencefriheden, den nyttige kappestrid til det almene bedste - $\mathrm{i}$ kirken, $\mathrm{i}$ skolen, i det politiske liv.

77 En vis affinitet til folkelighedstemaet har Inge Adriansens betragtninger over "Grundtvigs bidrag til udvikling af danske nationale symboler" (GrSt 2006). Hans "særlige sammenfletning af kristen, national og social identitet" har tydeligvis haft megen medvind. Symbolerne opfattes gerne som folkedybets emanationer. For eksempel blev kongemagtens himmelfaldne flag først i 1854 frigivet til folkelig brug, skønt Grundtvig talte under og om det på Skamling i 1844 og lod krigerne drage af sted med dets navn på læben i både 1848 og 1864: "Hil dig, vor Fane! Kors-Banner hvidt!" Til mangfoldigheden af "uofficielle" symboler bidrog han med mytologisk gods (som især folkehøjskolen tog til sig), han udpegede prisværdige historiske figurer og situationer, han aflyttede modersmålet dets himmelske lyd, indskrev det danske landskab i sange og salmer, osv. Sammensvejsningen af national og kristen identitet har den bagside, at symbolikken kan tjene også til minoritetsudgrænsning. 
I denne sammenhæng kan nævnes Vagn Wåhlins grundige redegørelse for Grundtvigs økonomiske tænkning (GrSt 1989-90), hvor netop engelsk liberal økonomi spillede en positiv rolle. Grundtvig var, som det vises, orienteret i den sene oplysningstids og samtidens økonomiteoretiske retninger, og specielt hvad angår handelsfrihed på linje med liberaløkonomerne. Det program, han formulerede i forsommeren 1848 , vidner om en økonomisk helhedsopfattelse, som han gerne ville drage de politiske konsekvenser af. Få skulle have for meget og færre for lidt, og øvrigheden måtte til den ende "alvorlig stræbe, ved den størst muelige Nærings-Frihed og Eiendoms-Sikkerhed, at fremme den jævne Velstand og ønskelige Ligevægt”. Den betænkelighed vedrørende dehumanisering i den ikke-regulerede industrielle udviklings kølvand, som iagttagelser i England havde fremmet hos ham, er kun lige netop antydet - her til lands er der, "Gud skee Lov!", kun få store fabrikker. $^{7}$

I GrSt 1994 aftrykker og analyserer Wåhlin det skrift, som Grundtvig udgav i 1831 under titlen Politiske Betragtninger med Blik paa Danmark og Holsteen. Artiklen udskiller en række vigtige punkter i skriftets samfundsforståelse og skitserer deres forhistorie (for fædrelandskærlighedens vedkommende tilbage til Willemoes-teksterne) og videreudvikling - "med stigende klarhed" - frem til Grundloven, med især skrivefriheden som betydningsfuld faktor i den opinionsregulerede enevælde, som Grundtvig foretrak, ind til det repræsentative demokrati blev en kendsgerning.

Som bekendt blev Grundtvig medlem af Den grundlovgivende Rigsforsamling og af den første "ordinære" Rigsdag. Kaj Thaning (GrSt 1949) og Erik Møller (GrSt 1950) gør begge detaljeret rede for forløbet, der også havde en "privat" side, idet sønnerne nærede en tillid til martsministeriet, som faderen på ingen måde kunne goutere. Han stiftede ugeskriftet Danskeren og anlagde i det hele en national linje. Det drejede sig om "Danskhedens Redning". Grundtvig forfægtede det synspunkt, at landegrænsen burde følge sproggrænsen ("midt inde i hertugdømmet Slesvig"). ${ }^{79}$ Som partiløs politiker så Grundtvig sig "i egentligste Forstand som Danskhedens Talsmand". Han undveg

\footnotetext{
78 Vagn Wåhlin har betænkt GrSt med flere bidrag om Grundtvig og de folkelige bevægelser, som vil blive omtalt i denne artikels del II. Jf. Kim Arne Pedersens nekrolog i denne årgang.

79 Jf. Morten Bredsdorff, "Digteren Goldschmidt om Grundtvig" (GrSt 1974). Den jødiske forfatter foreslog en unionsløsning efter svejtsisk model på det slesvig-holstenske problem, hvilket fik Grundtvig til at fraskrive ham retten til at ytre sig om dette danske anliggende. En opfølgende artikel af William Michelsen, "Om Grundtvig som europæer”, sætter affæren i videre sammenhæng.
} 
de populære standpunkter og måtte se sine mærkesager falde. Han fandt almindelig værnepligt uforenelig med den vundne frihed. Han kunne notere en vigtig sejr, hvad angår offentlighed og mundtlighed $\mathrm{i}$ retsplejen, og fik flertal for ændringen af 'Emanation' til 'Udstedelse', et dansk og folkeligt ord frem for de akademiske juristers latinske fagudtryk. Ved afstemningen om grundlovens helhed glimrede han ved sit fravær. Hvad krigen angår, talte han for en stærk militær satsning mod oprørerne, imod våbenstilstand og efter krigshandlingernes genoptagelse for at levere et løvemodigt hovedslag, hvor Gud så måtte levere åndelig ammunition, hvis hæren - større end den, hvormed Aleksander den Store erobrede "den halve Verden" - kom i betryk. Den nye våbenstilstand efter Fredericia-udfaldet bragte ham til at rase. Møller mere end antyder, at især det journalistiske korstog i Danskeren har medvirket til den almindelige reaktionsbefordrende skuffelse over begivenhedsforløbet. Hvad angår krigen, så talte han nu, efter Isted-sejren, for en fred, hvor Slesvig helt og fuldt tilfaldt Danmark, der uanset sindelag og sprog havde "Eiendoms-Ret" til Slesvig, men ingen ret til Holsten. Et Ejder-standpunkt, altså. I det hele taget gør artiklen op med megen mytedannelse omkring Grundtvigs politiske virke under Treårskrigen. Hans standpunkter var labile, og hans polemik gik ofte fejl af modstanderargumenterne. Han ville (med Thanings formulering) "hellere frihed uden orden end orden uden frihed". 80

Det var ikke - som mange mener - Grundtvig, men Fr. Barfod, der i grundloven fik indført passusen om, at censur "kan ingensinde paany indføres". Flemming Lundgreen-Nielsens "Grundtvig og censuren" (GrSt 2007) redegør detaljeret for forskydninger i Grundtvigs syn på og kamp for trykkefriheden, frem til censurens bortfald netop ved grundloven. At ungdomsvennen Skougaard kom i fedtefadet, bragte ham tidligt problemet tæt ind på livet. Siden oplevede han jo selv at komme under censur, og ofte beskæftigede han sig med loven og dens håndtering på skrift, for eksempel i 1827-afhandlingen "Om ReligionsFrihed", hvis sidste del i øvrigt blev bortcensureret. Censuren blev han fritaget for efter 11 år, uden at den trods alt havde været ham til væsentlig gene. De kongelige agenter holdt også øje med hans udfoldelse som taler. Et udkast fra 1844 til en ny trykkefrihedslov gav anledning til en pjece, som bliver grundigt gennemgået, og som afviser udkastet, fordi det ikke "forener en regerings evne til at handle frit med et folks mulighed for at tale frit". Under grundlovsforhandlingerne i 1849 formulerede han som sit mål at kæmpe for "en i borgerlig Henseende saa godt som uindskrænket Frihed for Mund og Pen". Hans udebliven fra selve afstemningen skyldtes, at tendensen $i$ det hele taget gik i en an-

80 I GrSt 1987 gengives et Grundtvig-indlæg om grundlovens folkekirkeparagraf. 
den retning. Et sidste livtag med problemet tog han i debatten om pressefrihedsloven, der forekom ham så tendentiøst formuleret, at han ikke kunne gå ind for den. I en slutvignet diskuteres det bevingede ord fra "Rim-Brev til Nordiske Paarørende" om friheden, der skal være "for Loke saavelsom for Thor" (vers 220), som gerne forstås løsagtigt, hen i retning af: "Samme frihed for alle".

Det er K. E. Bugges fortjeneste at have gjort det kendt, blandt andet via et bidrag til GrSt 2005, at Grundtvig i 1839-48 var medlem af den såkaldte Slavekommission, oprettet efter tilskyndelse fra en engelsk abolitionistorganisation. Han deltog altså i forberedelsen af Stænderforsamlingens indstilling til Christian VIII om at bringe slaveriet på de dansk-vestindiske øer til ophør. Dekretet herom blev jo effektueret af Peter von Scholten med bemærkelsesværdig hast. I en rigsdagstale afviste Grundtvig spørgsmålet om erstatning til slaveejerne: det er ikke muligt, endsige acceptabelt, at et menneske kan eje et medmenneske.

Tine Damsholt redegør i artiklen " Jeg er en gammel Royalist, det ved De nok' ..." (GrSt 1995) for elementer i Grundtvigs politiske tænkning. I samklang med 1700-tallets kontraktteori var hans ideal "en enevældig konge, der lytter til en fri folkestemme fra et oplyst folk" - altså hvad J. A. Seip har kaldt opinionsstyret enevælde. Når Grundtvig udeblev fra grundlovsafstemningen, var det ud fra den opfattelse, at loven i realiteten vidnede om "mistillid til folkestemmen og folkeviljen". På den anden side indså han, at der måtte finde en "folkeliggørelse" af almuen sted, til hvilken ende den folkelige højskole skulle tjene. Den franske revolution kørte løbsk, fordi "den uoplyste pøbel" kom til magten; den udviklede ikke nogen instans til afgørelse af, hvad der var til alles bedste. ${ }^{82}$

81 Allerede en "ironisk slutreplik" i Lundgreen-Nielsens artikel om Grundtvigs nordisk-mytologiske billedsprog i GrSt 1994 pointerer, at vendingen gerne anvendes forkert.

82 Kim Arne Pedersen har i GrSt 2004 offentliggjort og kommenteret et par hidtil utrykte tekster fra o. 1840, hvori Grundtvig skitserer sine tanker om "samfundspagt, gensidig frihed og menneskerettigheder". Enhver samfundsdannelse baserer sig på en kontrakt mellem Gud og menneske og subsidiært mellem konge og folk. Pedersen pointerer, at teksternes "tilslutning til de universelle menneskerettigheder" fortjener at ihukommes i en tid, hvor Grundtvig ofte udgives for at være ubesmittet af oplysningstænkning. 


\section{Personregister}

En parentes med et N efterfulgt af årstal, for eksempel (N2002), markerer, at der henvises til en nekrolog over vedkommende i den pågældende årgang af Grundtvig-Studier.

Adriansen, Inge 79

Albeck, Gustav (N1995) ... 22, 24, 26, $35,36,37,38,39,49$

Aleksander den Store 81

Allchin, Arthur McDonald .......62, 64

Andersen, Balder Mørk ...................78

Andersen, H. C. ......................21, 38

Andersen, Ingeborg ........................20

Andersen, Vilhelm ...........................35

Ansgar .............................................. 44

Aquinas, Thomas ............................. 48

Aristoteles .......................................67 67

Arnholtz, Arthur ............................. 70

Aronson, Harry …...............21, 52, 62

Augustin ...68

Auken, Sune $21,43,44$

Baggesen, Jens 37,41

Balle, Nicolai Edinger 67

Balling, Jakob .75

Balslev-Clausen, Peter ............ 71, 72

Bang, Jacob Peter ............................. 46

Bang, Jørgen .................................. 71

Barfod, Frederik ............................. 81

Beda ............................... 45, 46, 47

Begtrup, Holger .......................35, 40

Bergentz, Sven ...............................21

Bergstedt, Bosse ............................. 21

Bevans, Stephen B. ..........................68

Billing, Einar .....................................63 63

Birkelund, Regner ...........................2 21

Bjerg, Svend ....................................58

Boas, Hans Henrik ............................62 62

Boisen, Peter Outzen ........................50

Bolton, Clara ............................40, 65

Borum, Poul (N1997) ..............22, 36

Borup, Morten .................................37

Bradley, S. A. J. .... 21, 22, 27, 44, 45, 46, 47, 48, 73

Brammer, Gerhard Peter .................25

Brandes, Georg .........................35, 79

Brandt Nielsen, E. ............................26

Brandt, Carl Joakim .................24, 26

Brask, Peter ....................................... 76

Bredsdorff, Morten ..................49, 80
Brorson, Hans Adolph ............. 32, 70

Bugge, Knud Eyvin .....21, 25, 49, 67, 68, 82

Buhl, Peter Neerup ....................... 79

Bultmann, Rudolf ............................ 55

Burney, Fanny ................................. 40

Bøje, Grete .................................... 56

Bøye, Merete .....................48, 64, 73

Baagø, Kaj ............................. 56, 79

Cappelørn, Niels Jørgen ................. 59

Christensen, Bent .........21, 53, 54, 55

Christian VI ............................ 40, 77

Christian VIII .......................... 76, 82

Clausen, Henrik Nicolaj ....28, 55, 56, 61,65

Coleridge, Samuel Taylor .............. 64

Cour, Paul la ..................................... 40

Cynewulf ........................................ 73

Dam, Poul ...................................... 56

Damsholt, Tine .............................. 82

Danneskiold-Samsøe, Christian 26, 41

Disraeli, Benjamin ......................... 40

Ditlevsen, Kirsten ............................ 33

Dons, Povel .................................... 41

Egebak, Niels ................................. 71

Egede, Hans ................................... 68

Ehnevid, Tord (N2000) ........... 21, 63

Eichberg, Henning .......................... 31

Elbek, Jørgen ........................... 39, 40

Engelstoft, Laurits .......................... 29

Ertner, Jørgen ................................ 76

Eskedal, Anders ............................... 26

Ewald, Johannes ...................... 73, 74

Faber, Nicolai ................................. 25

Fehrman, Carl ................................. 49

Fenger, Peter Andreas ................... 44

Fibiger, Mathilde ............................ 33

Franklin, R. William ...................... 65

Frederik VII .................................... 42

Frisch, Hartvig ................................ 23

Geijer, Erik Gusaf ......................... 35

Gjesing, Knud Bjarne ..................... 31

Glenthøj, Elisabeth Albinus .......... 78

Goiske, Peder Rosenstand ............. 68 
Goldschmidt, Meïr Aron ................ 80

Gosse, Edmund ............................ 26

Grane, Leif (N2001) ...................... 57

Gregersen, Niels Henrik .......... 65, 74

Grell, Helge (N2000) ...21, 32, 48, 62, 68

Grundtvig, Johan 67

Grundtvig, Lise

Grundtvig, Svend 24,27

Grønbech, Vilhelm 55

Grønbæk, Villiam (N1970) 23, 27, 66

Hansen, Uffe (N1995) 39,64

Harbsmeier, Eberhard 24

Harbsmeier, Götz (N1979) ............ 60

Harrits, Flemming .......................... 71

Heaneys, Seamus .............................. 46

Heggem, Synnøve ............ 21, 23, 32

Helweg, Hjalmar ............................ 26

Helweg, Lise ................................. 76

Henningsen, Hans ............................ 64

Henriksen, Aage ............................ 54

Herder, Johann Gottfried von . 27, 30, 34,49

Hersleb, Svend ................................ 37

Hertz, Henrik ................................... 38

Hickes, George ............................... 46

Holberg, Ludvig ..................... 48, 68

Holm, Jette ............................ 71, 76

Holmberg, Anders .......................... 68

Holt, Else Kragelund ...................... 40

Hostrup, Christian ......................... 76

Høirup, Henning (N1996) .21, 22, 23,

$24,25,26,28,41,48,60,62,68$

Haarder, Andreas ..................... 44, 48

Ingemann, Bernhard Severin ... 39, 43

Irenæus ..................33, 43, 51, 52, 59

Jacobsen, Anders-Christian ........... 52

Jasper, David .................................... 64

Jensen, Henrik Fibæk ..................... 31

Jensen, Jørgen I. ..................... 22, 71

Jensen, Thorkild Borup .................. 71

Jessen, Erland .................................. 29

Jessen, Peter Neergaard .................. 78

Johannes (evangelisten) .................. 51

Johansen, Steen (N1987) ...23, 24, 25, 27

Jonas, Uffe ...................................... 33

Jungersen, Frederik ........................ 60

Jørgensen, Ellen .............................. 44

Jørgensen, Theodor ......54, 57, 63, 74

Kant, Immanuel ...................... 28, 66

Kelstrup, Erik ......................... 28, 59

Kiel, Ulla ........................................ 52
Kierkegaard, Søren 21, 30, 31, 32, 59, 60,63

Kingo, Thomas …..............51, 70, 71

Knudsen, Jakob .........................44, 50

Koch, Hal ................................23, 36

Kopernikus, Nikolaus ......................35

Korsgaard, Ove .........................31, 58

Kruuse, Jens ...................................... 45

Kuhn, Hans ..................................... 50

Kühnhold, Christa ...........................60 60

Kædmon ....................................45, 46

Larsen, Ejvind ...............................53

Larsen, Finn Stein .....................36, 71

Lathrop, Gordon W. .........................62 62

Laub, Thomas ................................. 70

Lessing, Gottfried Ephraim ............. 34

Leth, Constance ........................26, 49

Lindberg, Jacob Christian ..............69

Lindhardt, Poul Georg (N1988) .....54

Lodberg, Peter ..................................61

Lundgreen-Nielsen, Flemming 21, 22 , $25,36,41,42,43,44,50,62,67$, $72,73,79,81,82$

Luther, Martin . 27, 40, 56, 57, 58, 59, $61,62,67$

Lyby, Thorkild C.

Løgstrup, Knud Eiler ................60, 65

Madsen, Jens Kristian .....................24

Malone, Kemp (N1972) ............44, 45

Martensen, Hans Lassen .................23

Meincke, Inga ................................. 30

Michelsen, William (N2002) ..21, 22, $23,25,27,28,29,30,31,32,33$, $36,41,52,60,61,65,66,68,71$, $72,73,79,80$

Mikkelsen, Inger Lise .................... 75

Moltmann, Jürgen ...........................65

Montgomery, James ........................ 71

Müller, Heinrich ..............................68

Müller, Sigurd .........................36, 69

Mynster, Jacob Peter .......................23

Möhler, Johan Adam .......................65

Møller, Erik ..................................... 80

Møller, Jens ....................................67 67

Napoleon Bonaparte ........................30

Nielsen, Helge Baden .....................67

Nielsen, Jakob Fløe ......................... 72

Nielsen, Jens A. ...............................26

Nielsen, Mikkel Crone .....................55

Nielsen, Valdemar (N1973) ....25, 41, $42,55,72,73$

Nilsson, Gert

Noack, Bent 44,72 
Nyegaard, Marie Louise ..........43, 44

Nägele, Horst .............................30, 66

Overgaard, Ulrik .....................22, 25

Paulus .......................................... 49

Pedersen, Kim Arne .... 22, 23, 30, 32, $34,35,51,67,68,69,80,82$

Pius X .62

Platon 43,68

Polykarp ... 51

Prenter, Regin (N1991) 22, 56, 57, 68

Rask, Rasmus .....................................46

Rasmussen, Jens ..............................55

Reich, Ebbe Kløvedal (N2005) ......61

Reinhard, F. V. ................................ 34

Riisbrigh, Børge ............................28

Rod, Jakob ...................................51

Rode, Randi .................................. 44

Rothe, V. H. .................................. 25

Ryhede, Kai ..................................... 76

Rønne, Karl ........................................ 38

Sanders, Hanne ........................23, 51

Saxo Grammaticus .............27, 37, 49

Scharling, Carl Immanuel (N1951) $23,27,28,29,62$

Scharling, Henrik ..........................23

Schelling, Friedrich Wilhelm ..27, 28, 29, 34, 66, 68

Schiøler, Aage ....................... 73, 74

Schjørring, Jens Holger ....................22

Schmidt, Bodil ..........................23, 49

Schmidt, Frederik ........................... 37

Scholten, Peter von .......................... 82

Seip, Jens Lauritz Arup .................. 82

Shakespeare, William ...............49, 53

Sibbern, Frederik Christian 25, 50, 77

Simon, Erica (N1993) ......................23

Skautrup, Peter .................................. 71

Skougaard, Peter Nicolaj ... 26, 49, 81

Skriver, Svend .................................. 44

Smith, Adam .................................. 79

Spener, Philipp Jakob .....................61
Steffens, Henrich ...25, 27, 29, 41, 49, 56,74

Stenersen, Stener ...................... 37, 68

Stevns, Magnus .............................. 70

Stokholm, Anja ....................... 57, 58

Stub, Ambrosius ............................. 73

Sturluson, Snorri ............................ 27

Sverdrup, Georg ............................. 37

Sykes, Henrietta ............................. 40

Sølvbjerg, Knud ....................... 31, 32

Sørensen, Jørgen ........................... 70

Thaning, Kaj (N1994) .21, 22, 25, 29, $35,39,40,46,51,52,53,54,55$, $64,67,69,78,80$

Thodberg, Christian .....39, 41, 43, 59, $62,69,75,76,77,78$

Thomsen, Ejnar ............................... 38

Thomsen, Niels .............................. 43

Thorpe, Benjamin .......................... 47

Thunberg, Lars ............................... 39

Thyssen, Anders Pontoppidan (N2004) ..............52, 53, 54, 55, 61

Thyssen, Peter …........................... 70

Toft, Marie ............................ 33, 72

Toftdahl, Hellmut ...22, 23, 60, 61, 63

Toldberg, Helge (N1964) ..21, 23, 25, $38,39,52,76$

Treschow, Niels ............................. 37

Vind, Ole ..........21, 33, 34, 47, 51, 69

Vodskov, H. S. .............................. 35

Walstad, Pål Henning ..................... 21

Wesley, John .................................. 65

Wessel, Johan Herman ................... 73

Wigh-Poulsen, Henrik .............. 50, 65

Wolff, Christian von ....................... 28

Wordsworth, William ..................... 65

Wåhlin, Vagn ................................. 80

Ægidius, Peter .............................. 42

Ørsted, Hans Christian ............ 29, 34

Aarnes, Sigurd Aa. (N2007) ... 21, 23, $28,29,33,37,48$

Aasen, Kirsti

23,33 